UCR L-53179-82

Distribution Category UC-20,20D

\title{
DISCLAIMER
}

This report was prepared as an account of work sponsored by an agency of the United States Government. Neither the United States Government nor any agency thercof, nor any of their employees, makes any warranty, express or implied, or assumes any legal liability or responsibility for the accuracy, completeness, or usefulness of any information, apparatus, product, or process disclosed, or represents that its use would not infringe privately owned rights. Reference herein to any specific commercial product, process, or service by trade name, trademark, manufacturer, or otherwise does not necessarily constitiste or imply its endorsement, recommendation, or favoring by the United States Government or any agency thereof. The views and opinions of authors expressed herein do not necessarily state or reflect those of the United States Government or any agency thereof.

UCEI $--53179-82$

DEQS 001683

\section{Fire-Protection Research for DOE Facilities: FY 82 Year-End Report}

\author{
H. K. Hasegawa, N. J. Alvares,
}

A. E. Lipska-Quinn, D. G. Beason,

S. J. Priante, and K. L. Foote

Manuscript date: September 2, 1983

\begin{abstract}
NOTIGE
PORTIONS OF THIS REPOAT ARE ILLEGHLE.

It has been reproduced from the besi available copy to permit the broadest possible availability.
\end{abstract}




\section{Contents}

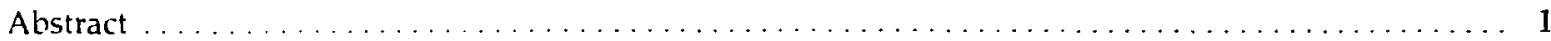

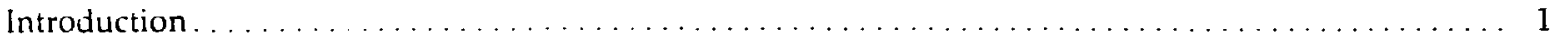

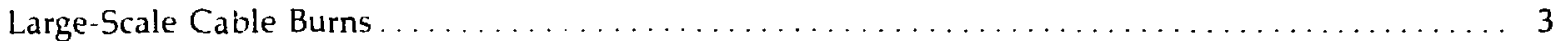

Small-Scale Cable Tests in the LLNL Ease-of-Ignition Apparatus $\ldots \ldots \ldots \ldots \ldots \ldots \ldots \ldots \ldots \ldots \ldots \ldots$

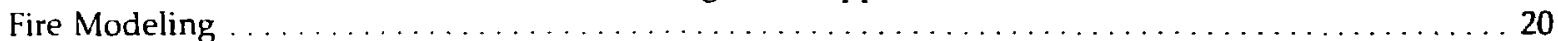

Fire Chemistry: Thermal Degradation of Cable and Wire Insulations $\ldots \ldots \ldots \ldots \ldots \ldots \ldots \ldots \ldots$

Fire-Risk Assessment of the TMX-U Magnetic Fusion Experiment $\ldots \ldots \ldots \ldots \ldots \ldots \ldots \ldots \ldots \ldots$

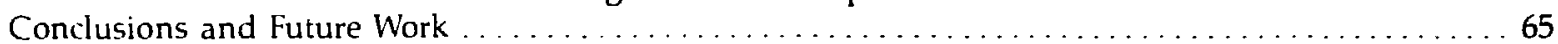

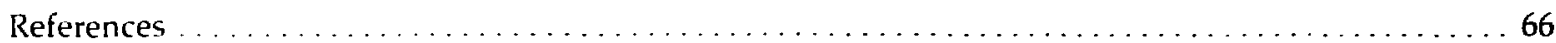

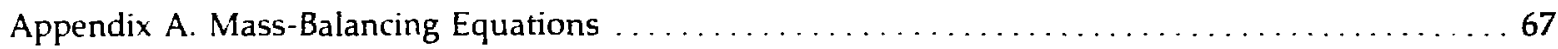

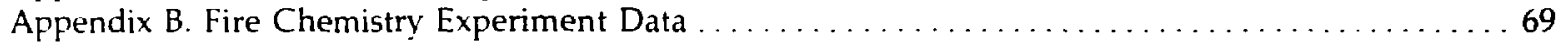




\title{
Fire Protection Research for DOE Facilities: FY 82 Year-End Report
}

\begin{abstract}
We summarize our research in FY 82 for the DOE-sponsored project, Firc Protection Research for DOE Facilities. This research program was initiated in 1977 to advance fireprotection strategies for energy technology facilities to keep abreast of the unique fire problems that develop along with energy technology research. Since 1977, the program has broadened its original scope, as reflected in previous year-end reports. We are developing an analytical methodology through detailed study of fusion energy experiments at Lawrence Livermore National Laboratory (LLNL). Usirig these experiments as models for methodology development, we are concurrently advancing three major task areas: $(1)$ the identification of fire hazards unique to current fusion energy facilities; (2) the evaiuation of accepted fire-management measures to meet and negate hazards; and (3) the performance of unique research into problem areas we have identified to provide input into analytical fire-growth and damage-assessment models.
\end{abstract}

\section{Introduction}

We report our work performed in FY 82 for a DOE-supported study entitled Fire Protection Research for DOE Facilities. Previous fiscal-yea- reports have been published. ${ }^{1-3}$ Note that the program title of this report has changed to a more general subject of DOE facilities. This reflects broadened programmatic goals that have evolved since 1977 . We feel the logic and analytical methodologies developed for fusion facilities can be applied to a range of emerging and established energy technologies. One ultimate goal of this study is the assessment of potential fire damage in such facilities. To accomplish this, three parameters have to be evaluated: (1) fire-threat potential to the facility, (2) response and effectiveness of fire-management systems, and (3) possible firerelated damage.

The milestone chart in Fig. 1 delineates the sub-tasks (marked by bullets) which must be completed to achieve our major goals (underlined) for this program. These major goals are all necessary to the ultimate objective: a standard guide of fire-management tactics for large DOE facilities. It is appropriate here to describe the logic and significance of each milestone as to its contribution to the final result. The sub-tasks listed under Fire Growth Parameters for Model Development are a combination of small- and large-scale fire experiments to provide appropriate data input for our modeling efforts and is also a partial modelvalidation tool. Those sub-tasks supporting Simoke Aerosol Production and Tramsport; Physical and Chemical Characteristics will help define two major phenomena: (1) the potential corrosive and particulate damage to experimental components, and (2) the particulate analysis (size, distribution, etc.) that will provide insight into the response times of smoke detection systems.

The next two milestones listed in Fig. 1 (.tidaptation of Modeling Techuique for Firr-Risk Asscisment and Advanced Fire Management System Development) integrate all results from the previous two milestones and are probably the most significant components to the program. They combine all the facets of what has been learned that can be applied to real tacilities. The modeling technique will predict the rate and extent of fire development in these facilities and the work on fire-management systems : vill define how detection and suppression response to predicted fires will modify the degree of fire damage. The Adianced Fire Man-gement System Deciclepment phate will concentrate on unique detection and suppression systems to deal with fire problems in DOE 


\section{PROJECT 6294-93 FIRE PROTECTION RESEARCH FOR ENERGY TECHNOLOGY PROJECTS}

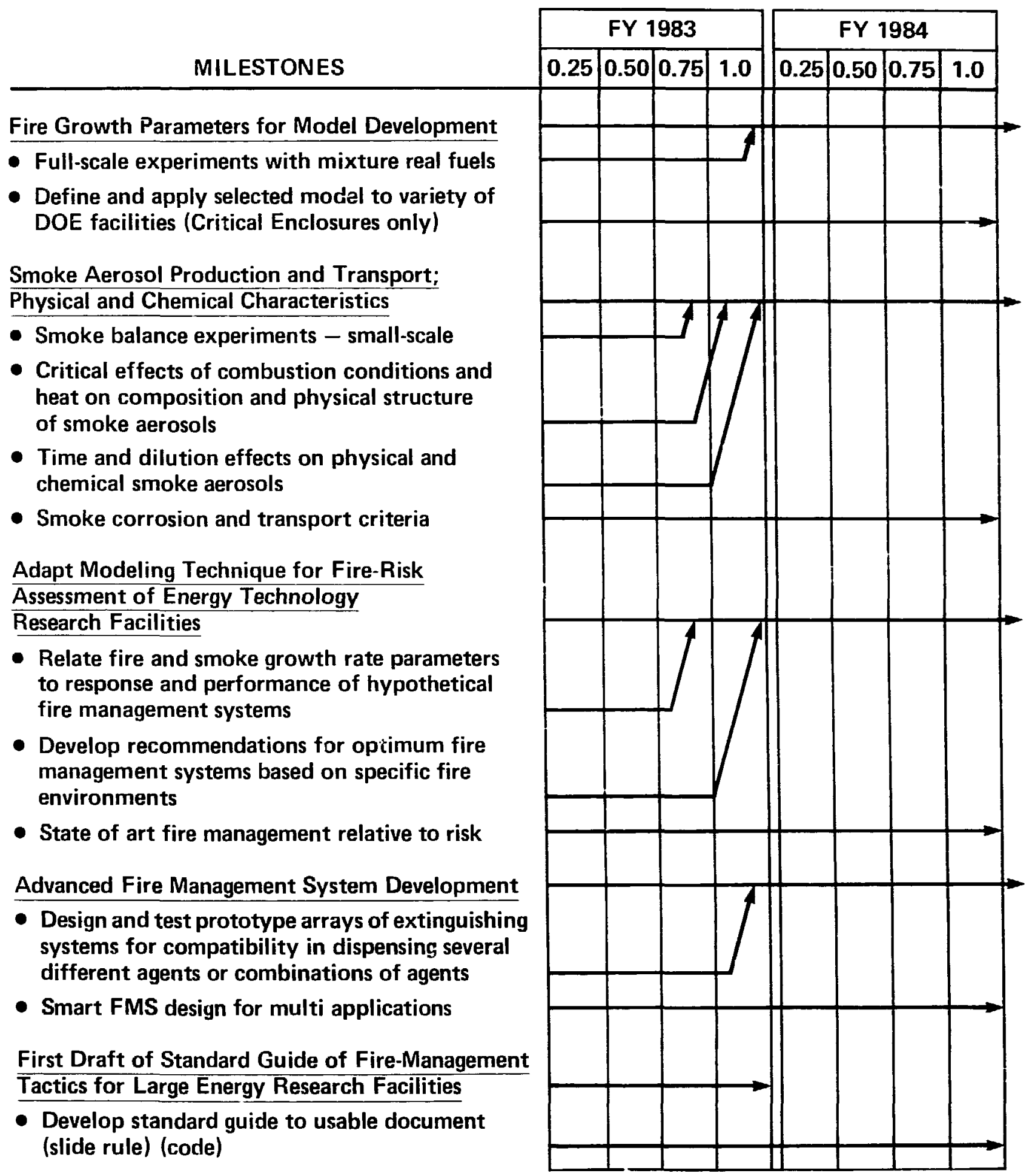

Figure 1. Descriptive chart of project milestones for LLNL fire-protection research for DOE facilities. 
facilities that traditional countermeasures cannot negate.

In FY 82, we made significant progress in a variety of task areas. In gentral, we reduced data from our model-validation experiments to a form that could be applied to the Zukoski (or Cal Tech) model $^{+}$so that our results could be accurately compared to data and results obtained from other fire models. Furthermore, we simplified the Cal Tech model to a closed-form integral, allowing faster and easier testing of the model. We were able to perform 27 inodel-validation experiments with a variety of closely defined fuels.

We performed a number of small-scale cable insulation experiments in the LLNL ease-ofignition apparatus. The results from this test series has led us to a research plan that will enable us to predict a cable type's relative time to ignition without having to fire-test it. At the other end of the spectrum, we also completed six large-scale vertical cable burns. We are gaining more insight into the effect of packing densities and configurations from these results. We have instigated a protocol to define these effects.

In the area of chemical characteristics of smoke aerosol, we determined the corrosive and noncorrosive chemicals produced during the main degradation phase of a large number of commercial plastic insulations and their virgin counterparts. Also, we studied the effect of the heating rate in air at the onset of initial decomposition of the various insulations.

Finally, we applied the protocol for fire-loss assessment to a major magnetic-fusion experiment here at LLNL.

\section{Large-Scale Cable Burns}

As described in previous reports, the major proportion of available flammable materials in energy research facilities are jacket and insulations for electrical conductors in control, power, and dia:mostic circuits. ${ }^{2.3}$ Although a close similarity exis!s between nuclear power plants and energy research facilities, there is a major difference in cable specifications and the manner in which cable runs are distributed throughout the plant. Specifically, the majority of wiring in nuclear fission plants musr meet the IEEE 383 standard for flammability ${ }^{5}$; the wiring is normally laid in cable trays according to a regulated protocol. In contrast, because energy research facilit.es are one-ofa-kind prototypes and are constantly changing their configurations, they must be flexible and much less rigorously structured, and this results in complicated and unconfined cable runs. Furthermore, the extremely high-power-carrying capacities required of these cables make specifications such as dielectric strength, flexibility, solvent resistance, etc. appear more important than fire resistance. Early in the project, we conducted literature searches and surveyed institutions performing cable fire research in the hope that others would be able to provide us with the fire data we needed. Unfortunately, as shown in Table $1,99 \%$ of the work was specifically applied to the cable-tray problems of nuclear power plants. $W$ ith the exception of generic material properties, the results from these studies could not be accurately extrapolated to energy facility problems.
Consequently, we initiated a cable-tesi program which began with small-scale experiments (ease-of-ignition, heat-release-rate calorimeter, TGA, etc.) that eventually provided input to our current series of large-scale vertical cable burns. We conducted large-scale experiments to obtain realistic fire data to account for as many variables as possible. These data will provide input to our fire-modeling efforts, and, hopefully, provide some correlation to small-scale tests. Ultimately, experimental results will aid in the specification of fire-safe cable materials for present and future DOE facilities.

\section{Large-Scale Vertical Cäułe Experiments}

We conducted large-scale fire experiments to define the effect of cable size, composition, number and packing density on the vertical flamespread rate, and, consequently, the massburning rate. However, many more parameters of interest can be measured on this scale, e.g., time of ignition; mass-loss rate; extent of flamespread; mass balance (quantity of smoke in proportion to mass-burning rate); combustion gas composition and rate of acid ion generation; oxygen consumption, and carbon monoxide, carbon dioxide, and hydrocarbon production; heat-release rate via oxygen depletion or carbon dioxide production.

These data can be compared to results from smail-scale tests to assess their correspondence to 
Table 1. Partial listing of organizations doing fire research on cables.

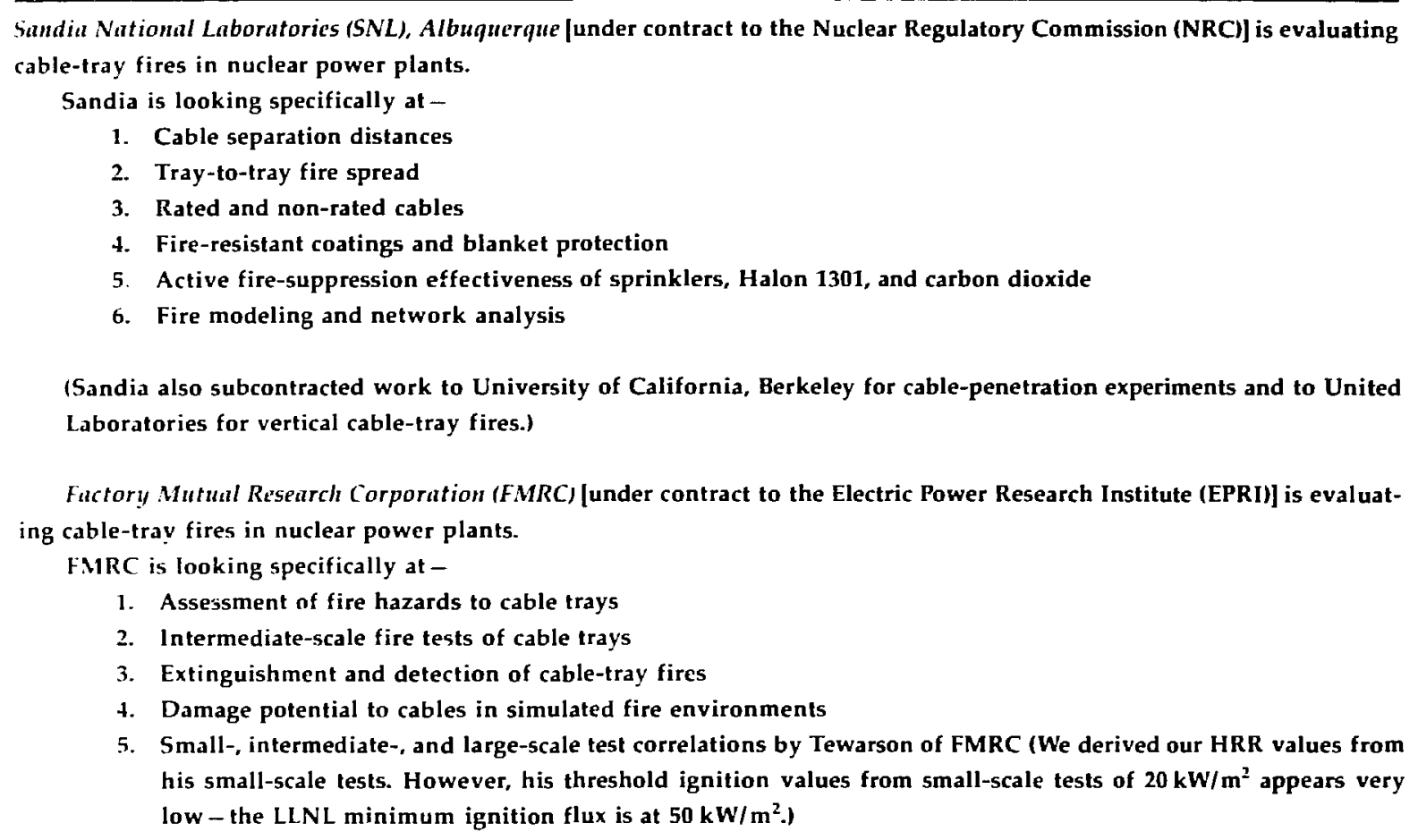

Bell Telephone of Canada and the National Research Council of Canada are doing general fire research on cables, particularly on telephone cable.

realistic conditions. Moreover, we can obtain specific fuel performance and enclosure fire parameters, e.g., the temperature profile through the fuel-array cross section and along the vertical surface, the temperature distribution throughout the test cell, and the enclosure ventilation changes resulting from the heat-release rate.

Figure 2 shows the experimental support structure for the vertical-cable runs. The bundle of electrical conductors is suspended from a steel cable threaded over two bicycle wheels (to decrease friction) and attached to a counterbalanced load cell. Adjacent to the specimen is a vertical, calibrated panel for visually observing the flamespread and glass sampling ports for combustiongas collection at mid-height and at the top of the specimen. Calorimeters and radiometers are located at the ignition source, near the specimen bottom, and at mid-height. Similarly, chromelalumel thermocouples are located at strategic points on the apparatus and throughout the test cell. To monitor the melting insulation that might $d_{i}$ ip from a burning cable, a load cell is placed directly under the specimen centerline. Since these droplets are generally aflame, the load cell also supports a drip pan partially filled with water. This weighing of cable melt is necessary to estimate mass balance and fuel-consumption rates.

\section{Ignition Source}

To provide an ignition source of finite dimension producing specified heat-flux levels, we constructed a premixed natural gas and air burner with gravel as a diffusion medium. This burner, with a $30-\mathrm{cm}$ o.d., produced a calibrated exposure flux of $5 \mathrm{~W} / \mathrm{cm}^{2}$ at an energy release rate of $20 \mathrm{~kW}$. A heat flux of $5 \mathrm{~W} / \mathrm{cm}^{2}$ or greater was identified as a threshold ignition energy from heat-release-rate experiments conducted at SRI, International. ${ }^{2}$

\section{Test Specimen}

The test specimens for this experimental series were two-layer cable bundles formed into a perpendicular " $Z$ " configuration as shown in Fig. 3. The vertical cable length was $1.8 \mathrm{~m}$. To prevent undefined heat-loss effects on cable-burning 


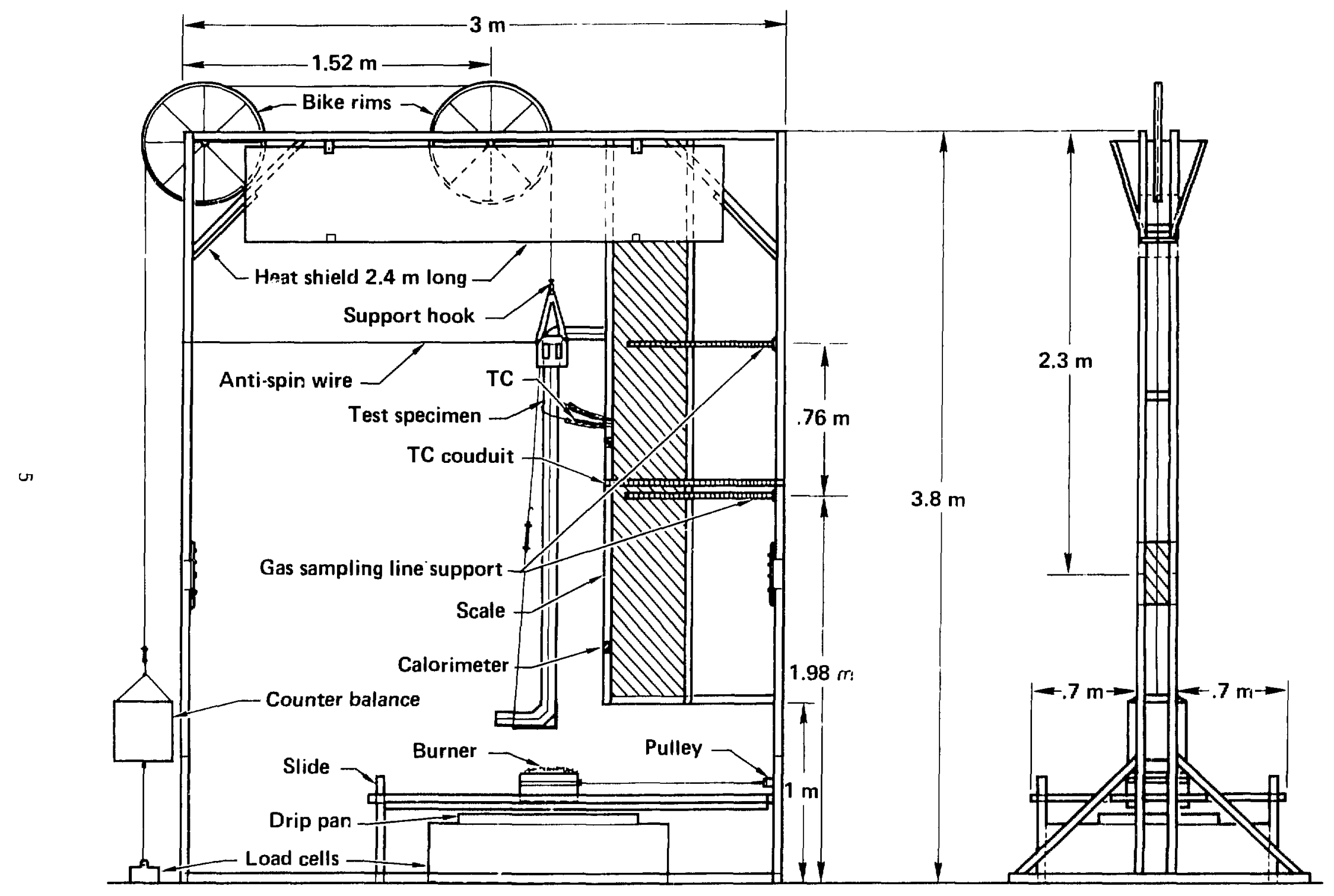

Figure 2. Experimental support structure for vertical cable burn (VCAB) experiments. 


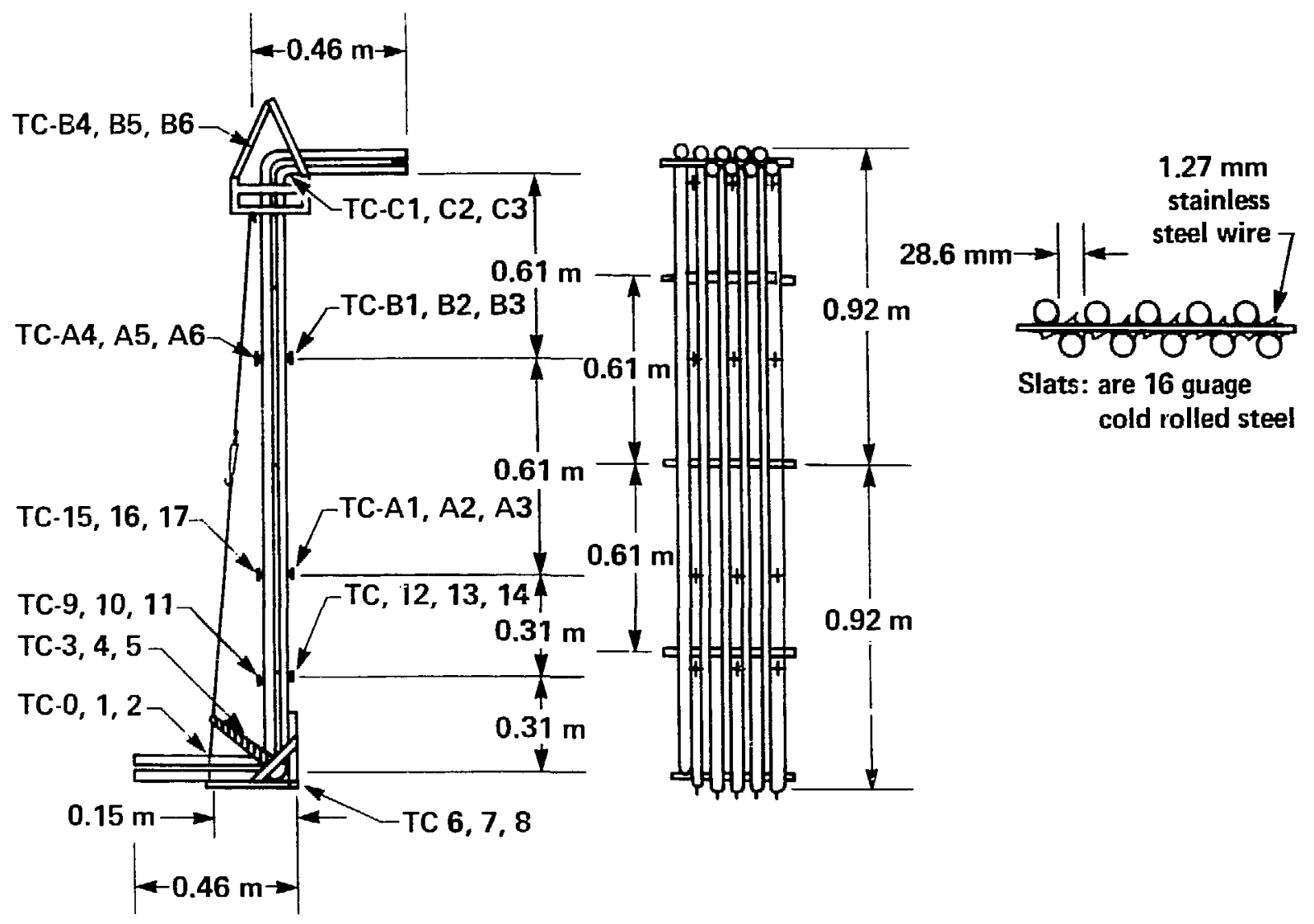

Figure 3. Thermocouple (TC) locations for vertical cable burns.

characteristics, we designed and fabricated special low-mass hardware to hold the cables. The verical configuration was cnosen to maximize the rate of flamespread and simulate a worst-case situation. To supplement our visual observations of fire growth, we attached thermocouples in a vertical array at approximately $0.4-\mathrm{m}$ intervals on both faces of the specimens as well as between the two layers of cables.

We performed six experiments, designated VCAB-1 through VCAB-6, in the LLNL Fire Test Cell, which is a negative-pressure ventilation enclosure with a $4.7-\mathrm{m}$ ceiling height and a total volume of $100 \mathrm{~m}^{3}$. Table 2 lists the cable types we tested and Table 3 shows pertinent physical data for the six tests. Figure 4 is a photo of the test setup. Figures 5 and 6 document VCAB- 5 during and after the experiment. The planned ventilation rate for the experimental series of $500 \mathrm{l} / \mathrm{s}$ was achieved in all tests except VCAB-1. Its ventilaticn rate is unknown due to an inadvertent closing of an exhaust damper.
Table 2 illustrates the variation in composition for the six cable experiments. An important variable is the percentage of conductor to jacket and insulation material. As in the small-scale ease-of-ignition tests, we must be able to identify (as well as possible) the individual effects of cable size, packing geometry, composition, and materials. Note both the Hypalon and Neoprene welding cables are about $80 \%$ stranded copper conductor. On the other hand, the PVC coaxial is $51 \%$ insulation and $49 \%$ conductor. The difference is the polyethylene insulation that accounts for $32 \%$ of the total weight. Once a comparison of these characteristics is made, we can begin to look at the results in Table 3 with a little more insight.

\section{Experimental Notes}

The first thrce experiments (VCAB-1 through -3) were "shake down" tests to evaluate the apparatus. From our observations and results, we established the following quasi-formal test protocol, which we will discuss point by point. 
Table 2. Summary of the physical characteristics of cuble types tested to date.

\begin{tabular}{|c|c|c|c|c|c|c|}
\hline VCAB & $\begin{array}{l}\text { Jacket mat'l } \\
\text { (\% wt.) }\end{array}$ & $\begin{array}{c}\text { Insulation } \\
\text { (\% wt.) }\end{array}$ & $\begin{array}{l}\text { Conductor } \\
\text { (\% wt.) }\end{array}$ & $\begin{array}{l}\text { Cable o.d. } \\
\text { (mm) }\end{array}$ & $\begin{array}{l}\text { Total wt. } \\
(\mathrm{kg} / \mathrm{m})\end{array}$ & \% Pack \\
\hline $1 \& 2$ & $\begin{array}{c}\text { Hypalon } \\
\text { (16.2) }\end{array}$ & none & $\begin{array}{c}\text { copper } \\
(83.8)\end{array}$ & 19.1 & 1.15 & 100 \\
\hline 3 & $\begin{array}{c}\text { Neoprene } \\
(\mathbf{2 3 . 5})\end{array}$ & none & $\begin{array}{c}\text { copper } \\
(76.5)\end{array}$ & 19.1 & 1.29 & 100 \\
\hline 4 & $\begin{array}{l}\text { PVC } \\
(18.9)\end{array}$ & $\begin{array}{l}\text { polyethylene } \\
\text { (32.1) }\end{array}$ & $\begin{array}{c}\text { copper } \\
(49.0)\end{array}$ & 25.5 & 1.12 & 100 \\
\hline 5 & $\begin{array}{l}\text { PVC } \\
(18.9)\end{array}$ & $\begin{array}{l}\text { polyethylene } \\
(32.1)\end{array}$ & $\begin{array}{c}\text { copper } \\
(49.0)\end{array}$ & 25.5 & 1.12 & 50 \\
\hline 6 & $\begin{array}{l}\text { PVC } \\
(18.9)\end{array}$ & $\begin{array}{l}\text { polyethylene } \\
\text { (32.1) }\end{array}$ & $\begin{array}{c}\text { copper } \\
(49.0)\end{array}$ & 25.5 & 1.12 & 25 \\
\hline
\end{tabular}

Table 3. Summary of cable-fire results.

\begin{tabular}{ccccccccc}
\hline VCA B & $\begin{array}{c}\text { Burner off } \\
\text { (min:s) }\end{array}$ & $\begin{array}{c}\text { Time to } \\
\text { ignition } \\
\text { (min:s) }\end{array}$ & $\begin{array}{c}\text { Total } \\
\text { flamespread } \\
(\mathbf{m})\end{array}$ & $\begin{array}{c}\text { Flamespread } \\
\text { rate } \\
(\mathbf{m} / \mathbf{s})\end{array}$ & $\begin{array}{c}\text { Avg. } \\
\text { HRR } \\
\text { (kW) }\end{array}$ & $\begin{array}{c}\text { Peak } \\
\text { HRR } \\
\text { (kW) }\end{array}$ & $\begin{array}{c}\text { Time of } \\
\text { HRR peak } \\
\text { (min:s) }\end{array}$ & $\begin{array}{c}\text { Test } \\
\text { duration } \\
\text { (min:s) }\end{array}$ \\
\hline 1 & $21: 30$ & $17: 00$ & 1.82 & 0.10 & 50.0 & - & - & $23: 30$ \\
2 & $20: 00$ & $15: 30$ & 1.82 & 0.36 & 79.9 & 350 & $27: 05$ & $31: 30$ \\
3 & $35: 45$ & $23: 15$ & 1.82 & 0.10 & 25.9 & 50 & $33: 20$ & $49: 15$ \\
4 & $25: 25$ & $23: 25$ & 0.91 & 0.09 & 12.8 & $15^{b}$ & 35.06 \\
5 & $12: 00$ & $10: 10$ & 1.82 & 0.18 & 182.5 & 550 & $20: 00$ & $25: 00$ \\
6 & $24: 25$ & no & 0.76 & 0.09 & 24.5 & 95 & $30: 50$ & $40: 00$ \\
\hline
\end{tabular}

A HRR = Heat-release rate.

b VCAB-4 zveraged $15 \mathrm{~kW}$, ring experiment.

(1) In an attempt to evaluate the effects of decreasing the overall mass and increasing the cable spacing, we conducted tests on three separate cable bundles for each cable type, as shown in Fig. 7. The first specimen was normally a full cable run ( $100 \%$ pack) that averaged 20 cables in 2 layers, with a net vertical run of $1.8 \mathrm{~m}$. The second specimen runtained half this number ( $50 \%$ pack), which allowed for a 1-cable diameter space between each cable. The third specimen contained half of this number, or approximately 5 cables (25\% pack), in a single layer.

(2) In addition to developing a packing protocol, we also modified the attachment of thermocouples on the cable bundle in tests VCAB-4 through -6 from surface mounting to imbedding the thermocouple $1.5-2.0 \mathrm{~mm}$ into the jacket insulation. Monitoring the actual jacket temperature is a more appropriate measurement, and it allows us to detect ignition at that point, which aids in both defining a threshold-ignicion temperature and the rate and extent of flamespread as well. The flamespread to an imbedded thermocouple's loca- tion is confirmed when it registers a temperature between $75^{\circ} \mathrm{C}$ and $80^{\circ} \mathrm{C}$. This technique for determining the flamespread rate has proven to be fairly consistent and is a more positive one than simple visual observation, which really does not accurately distinguish between actual flame attachmerit and flame extension "lapping." Figure 8 is a composite plot of the cable thermocouples located on the vertical run with their vertical locations noted where they cross the " $75^{\circ} \mathrm{C}$ " line. The time at which a plot crosses the straight line drawn at approximately $75^{\circ} \mathrm{C}$ is the elapsed time to flame travel to this point. (Another important note is that the $20 \mathrm{~kW}$ ignition source is not removed for several minutes after visual cable ignition has been observed.)

(3) We attempted to calculate the heatrelease rate of these experiments using both massloss rate and oxygen-depletion rate, but cive to the high ventilation rate $(500 \mathrm{l} / \mathrm{s})$ and sparse caiole burning, only two experiments depleted measurable quantities of oxygen. Consequently, the majority of heat-release-rate values for the various 


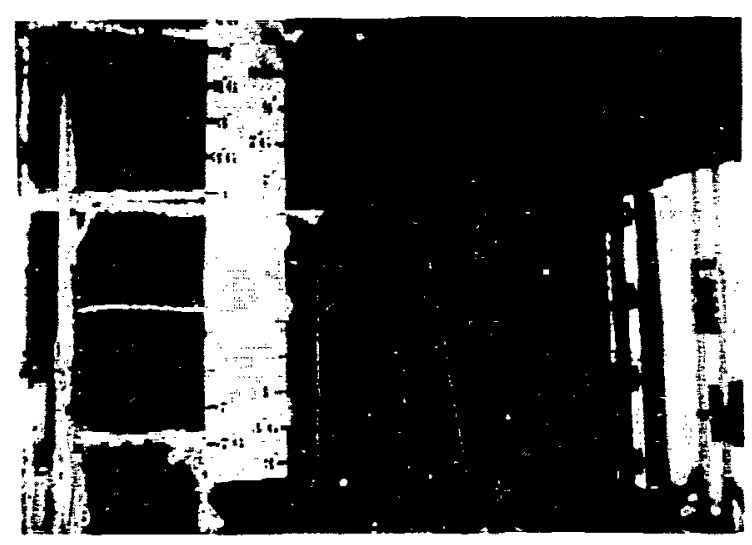

Figure 4. VCAB setup in LLNL Fire Test Cell.

experiments were derived from the mass-loss rate. Because many of the cable types are composed of several different polymeric materials, we had to use an average value for heat of combustion of the composite. For this reason, the oxygen depletion would be far more accurate and desirable.

\section{Results}

Experiments VCAB-1 and VCAB-2 (Hypalon jacket) were intended to be identical "shake down" tests. However, as mentioned previously, the ventilation rate in VCAB-1 was greatly reduced due to an inadvertant closing of the exhaust damper. Yet, studying the results listed in Table 3, this reduced airflow appeared to affect only the flamespread rate and the time-to-onset of mass loss. Referring to the latter, the rate of mass loss was essentially the same for both burns; however,

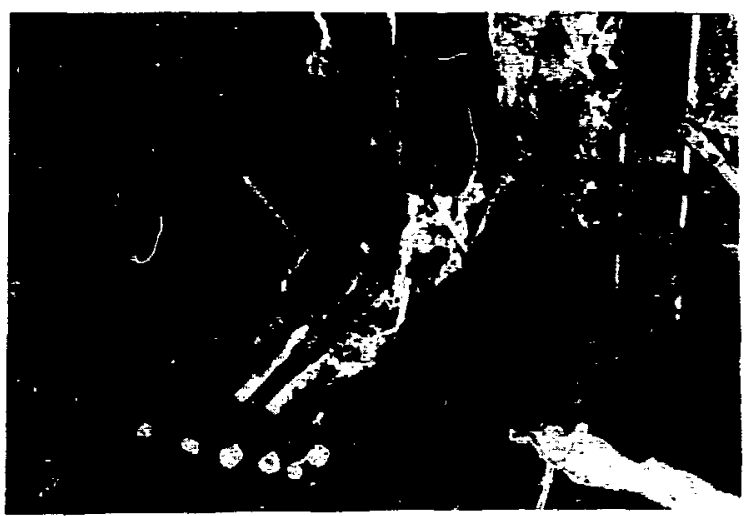

Figure 6. VCAB-5 at end of test burn.

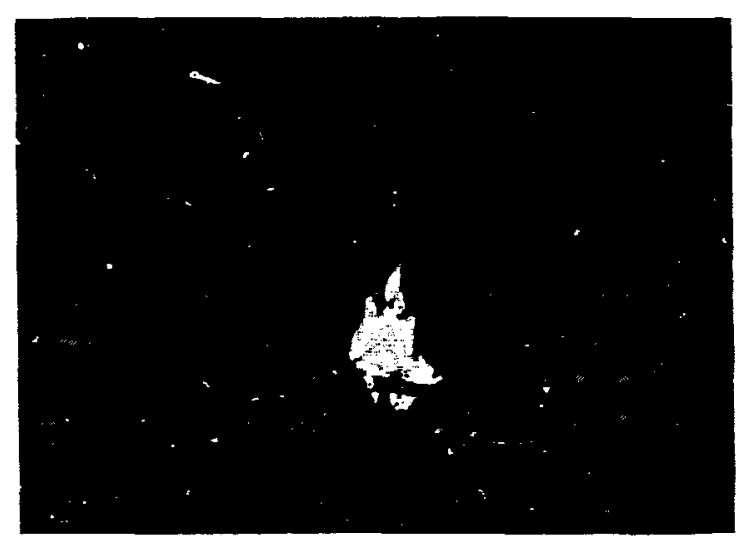

Figure 5. VCAB-5 during experiment.

VCAB-1 began losing weight $250 \mathrm{~s}$ later than VCAB-2. Similarly, VCAB-2 had a flamespread rate three times that of VCAB-1. All other parameters seem to be very close, indicating reproducibility.

A comparisc $n$ of VCAB-1 and VCAB-2 to the Neoprene-jacketed welding cable test (VCA.B-3) shows the effect different jacket materials have on cable fire performance. In this case, it is primarily a function of the material because all other variables, such as cable size, ratio of insulator to conductor, etc., were nearly identicai. Table 3 shows
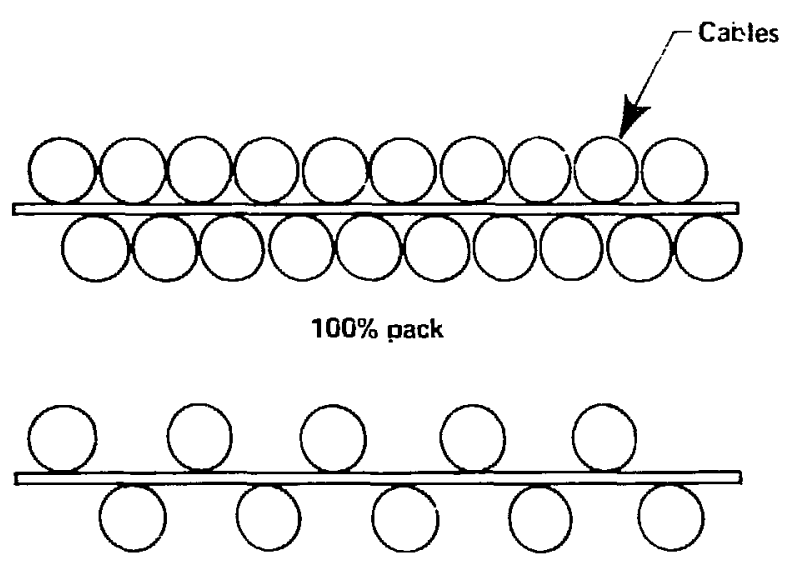

50\% pack

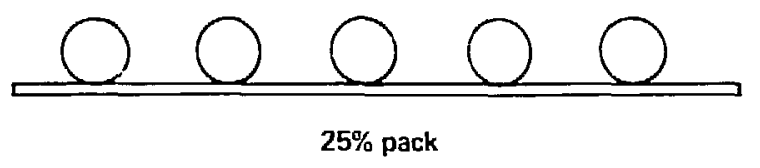

Figure 7. End view of test cable bundles showing different packing densities. 


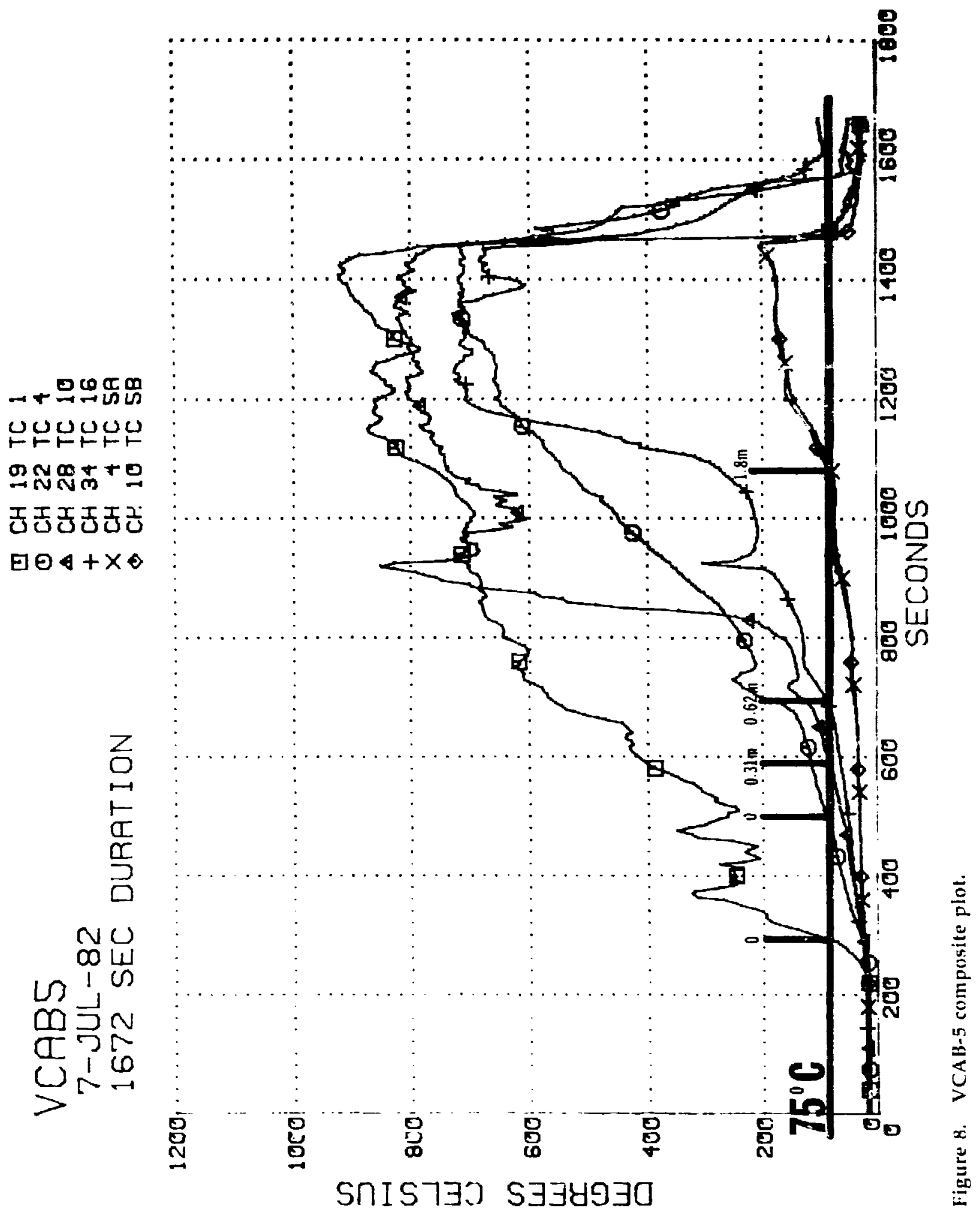


that the time-to-ignition, as well as the lapsed time-to-burner removal, is noticeably greater for $N$ soprene. Furthermore, Neoprene exhibited onethird the flamespread rate of Hypalon. In terms of heat-release rate, $\cdot$ ig 9 illustrates that Hypalon produces a much more severe fire. W'ith the exception of VCAB-i, which will be discussed later, all wther cable experiments produced heat-release rates of $50 \mathrm{~kW}$ or less as compared to a maximum of $200 \mathrm{~kW}$ for Iypalon. A preliminary conclusion from this limited data would be that the Neoprene cable required a higher ignition energy, and, once ignited. 1: produced a much slower rate of flamespi ad and heat release.

As shown in Table 3, VCAB-4 through -6 of the PVC-jacketed power cable with polyethylene insulation inaugurated the packing protocol described earlier for each cable type. Our results indicate that the $50 \%$-packed vertical run produced the worst fire. The burner was shut off in approximately half the time as VCAB- 4 and -6 , which means that ignition occurred relatively quickly. Similarly. the rate of flamespread is twice that of the others and the heat-release rate is an order of magnitude greater. Comparing the PVC $100 \%$ pack test to the Neoprene (VCAB-3) and Hypaion (VCAB-2), we see that the PVC $100 \%$ pack is lowest in total flamespread, heat-release rate, and flamespread rate. However, comparing the $100 \%$ pack Neoprene and Hypalon to the $50 \%$ pa: -1 . PVC, the $50 \%$ PVC is the hignest in all of the above categories, which gives some credence to varying the number and spacing of cables in the vertical array. We will continue to use our protocol in future experiments, as well as evaluate the effect of varying the ignition source strength. air- flow, cable composition (i.e., multiconductor vs solid copper, etc.), and cable diameter.

Finally, Figs. 10(a) and 10(b) compare the difference in heat-release rates between VCAB-2 and VCAB-5 using mass-loss rate vs oxygen depletion. In both cases, the curves show greater and greater dispersion as the intensity of the fires increase with time. This pronounced spread in the latter stages reflects the averaging of calorific values of heterogeneous materials and the uncertainty of actual polymer formulations, which makes the oxygen-depletion technique more accurate and desirable.

\section{Observations from Vertical Cable Burn Experiments}

Under the conditions of this experiment I series, we can make the following prelimiary observations:

- When exposed to the $20 \mathrm{~kW}$ ignition souice, the majority of cable types were very difficul' to ignite

- Once ignited, the flamesprend rate was very slow.

- Similarly, heat-release rates remained low and were slow to peak.

- Fire performance was du primarily to the power-cable diameter $(1.25 \mathrm{~cm}$ to $2.54 \mathrm{~cm})$ and large perce'itage of conductor, and the packing density $[100 \%=$ too dense, $50 \%=$ optimal (most severe fire), and $25^{\circ} \%$ = too sparse].

\footnotetext{
- Based on only ine test aeriea
} 


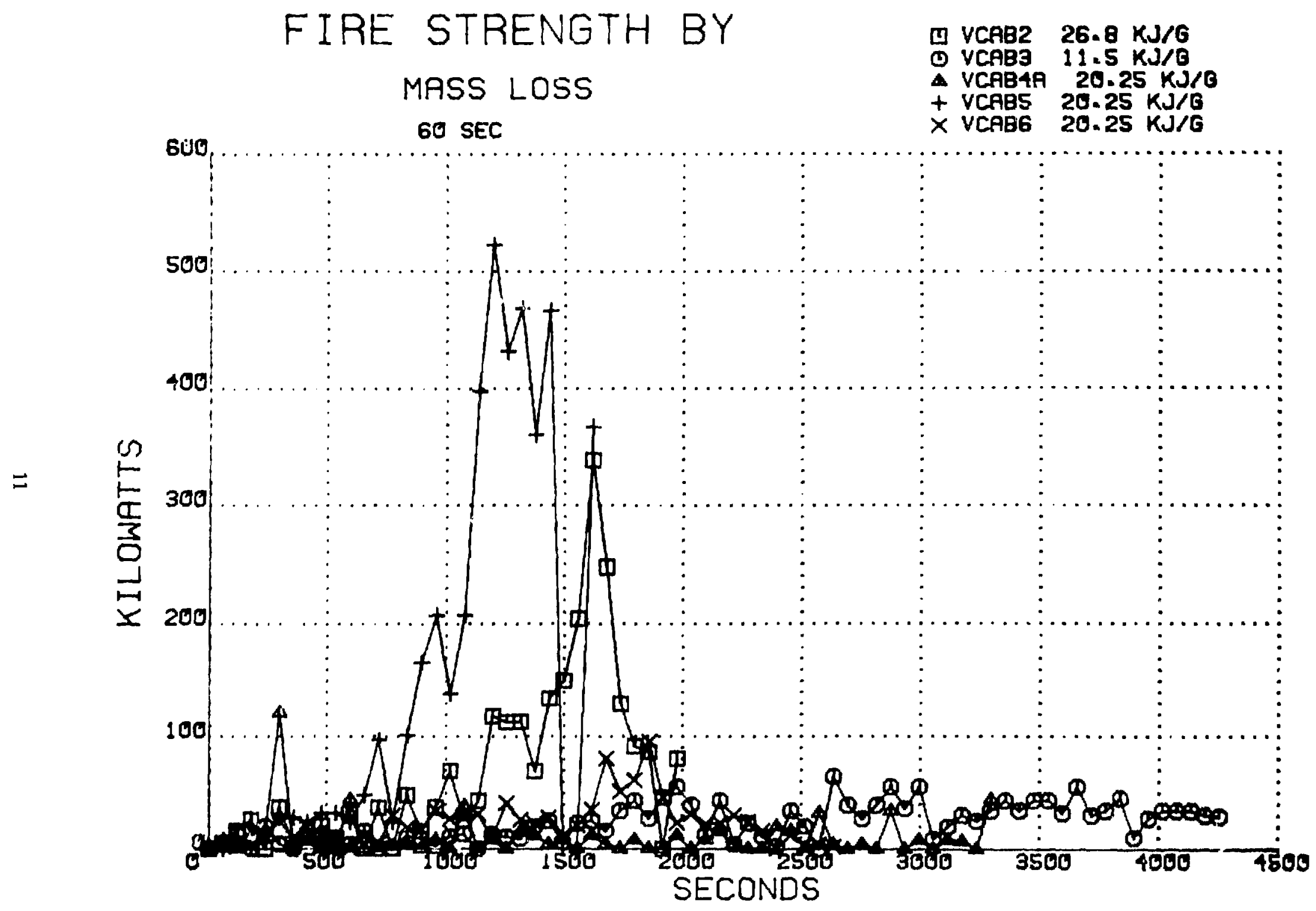

Figure 9. Heat-release rate graph of all VCABs. 
(a)

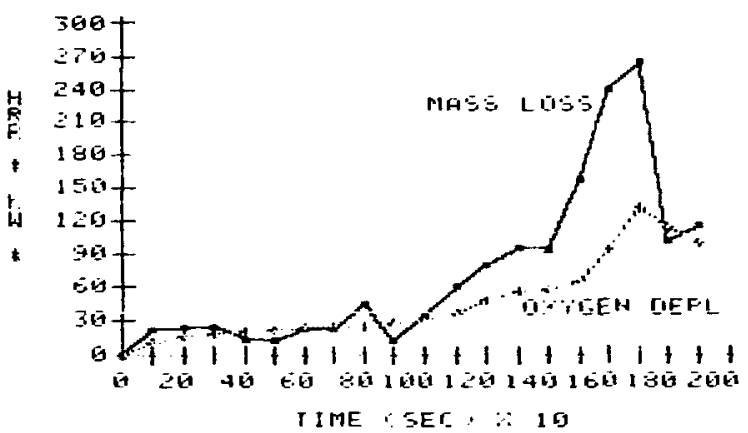

(b)

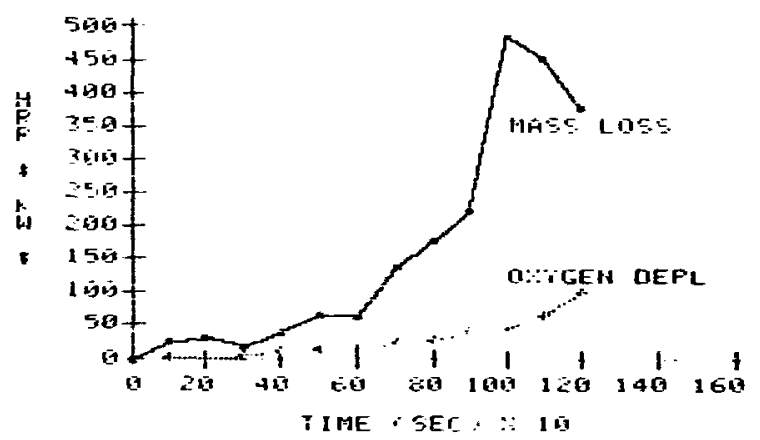

Figure 10. Comparison of heat-reiease rates of (a) VCAB-2 (Hypalon) and (b) VCAB-5 (PVC) using mass loss vs oxygen depletion.

\section{Small-Scale Cable Tests in the LI.NL Ease-of-Ignition Apparatus}

In FY 82, we were able to reartivate our easeof-ignition apparatus to perform experiments on apprciimately 22 cable samples which were identified in FY 81 as representat:ve types from LLNL stock. As mentioned in the FY 80 report, we are using the FY 80 performance standard as a research tool to obtain relative ignition rankings for electrical cable insulations. This ranking, in turn, provides a screening tool for large-scale cable fire tests.

\section{Summary of Test Method}

Figures 11 through 13 show the test apparatus and related instrumentation. Due to other experimental efforts, we were only able to include the thermopile, water-temperature thermocouple, and photodiode for this series (as opposed to the variety of monitors used in the pievious series). Two parallel vertical specimens, $140 \mathrm{~mm}$ wide and $152 \mathrm{~mm}$ high, face each other at a distance of $53 \mathrm{~mm}$ apart. The facing surfaces of both specimens are exposed to $a$ methane diffusion flame supplied from a multiported burner located below the lower edge of the specimens. The reason for having two specimens facing each other was to simulate the reinforcement that would occur in a worst-case fire situation.

The time to ignition is indicated both by the time at which a flame attachment on a specimen surface is observed and by the time when the specimens begin to contribute a significant quantity of fuel, as indicated by a rise in the voltage of a thermopile, which consists of a bank of thermo- couples located $6.4 \mathrm{~mm}$ above the top edge of each specimen and $6.4 \mathrm{~mm}$ out from the plane of their surfaces.

\section{Significance}

This method, as a standard, is intended to evaluate the relative ignitability of materials that form part of the exposed wall and ceiling surfaces of a room, including the vertical surfaces of fumiture, by determining the times to ignition when test materials are exposed to an extended-area flame source simulating the flame from a burning chair, waste basket, etc. The materials must be tested in the thicknesses at which they are intended to be used, unless it can be demonstrated that the time to ignition is independent of the thickness range being tested. However, we are using this concept with a different emphasis: because the above ignition scenario is a severe one, we are using this standard exposure to determine relative ease of ignition of a broad spectram of cable types and materials. Results from this method will help prevent unnecessary and costly large-scale fire testing.

\section{Test Specimens}

Eight rectangular cable specimens of each type of cable $140 \mathrm{~mm}$ wide and $152 \mathrm{~mm}$ high were tested in a specially designed specimen holder. Two specimens were required for each test, and four replicate tests were conducted. The specimen 


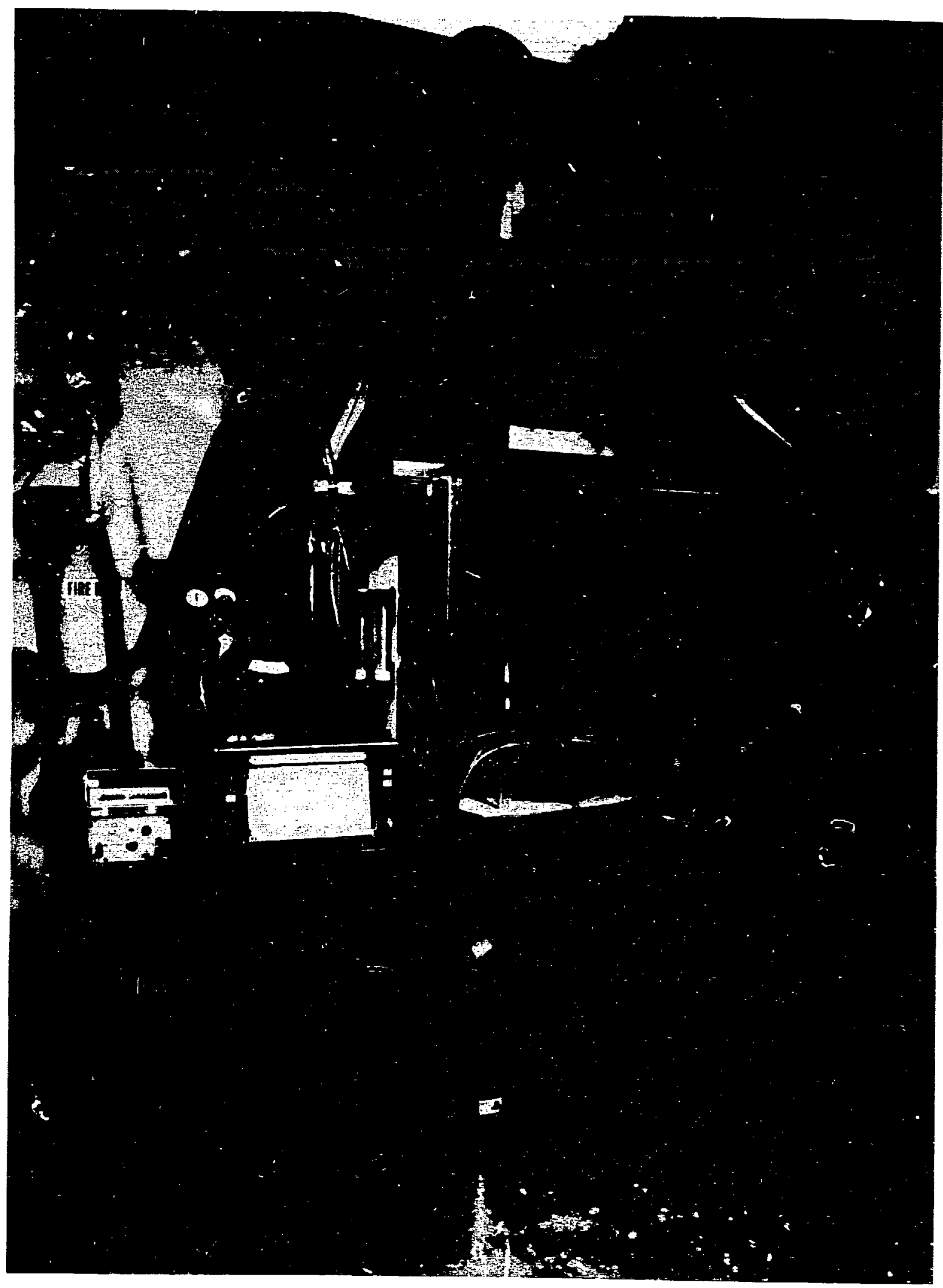

Figure 11. Ease-of-ignition test apparatus. 

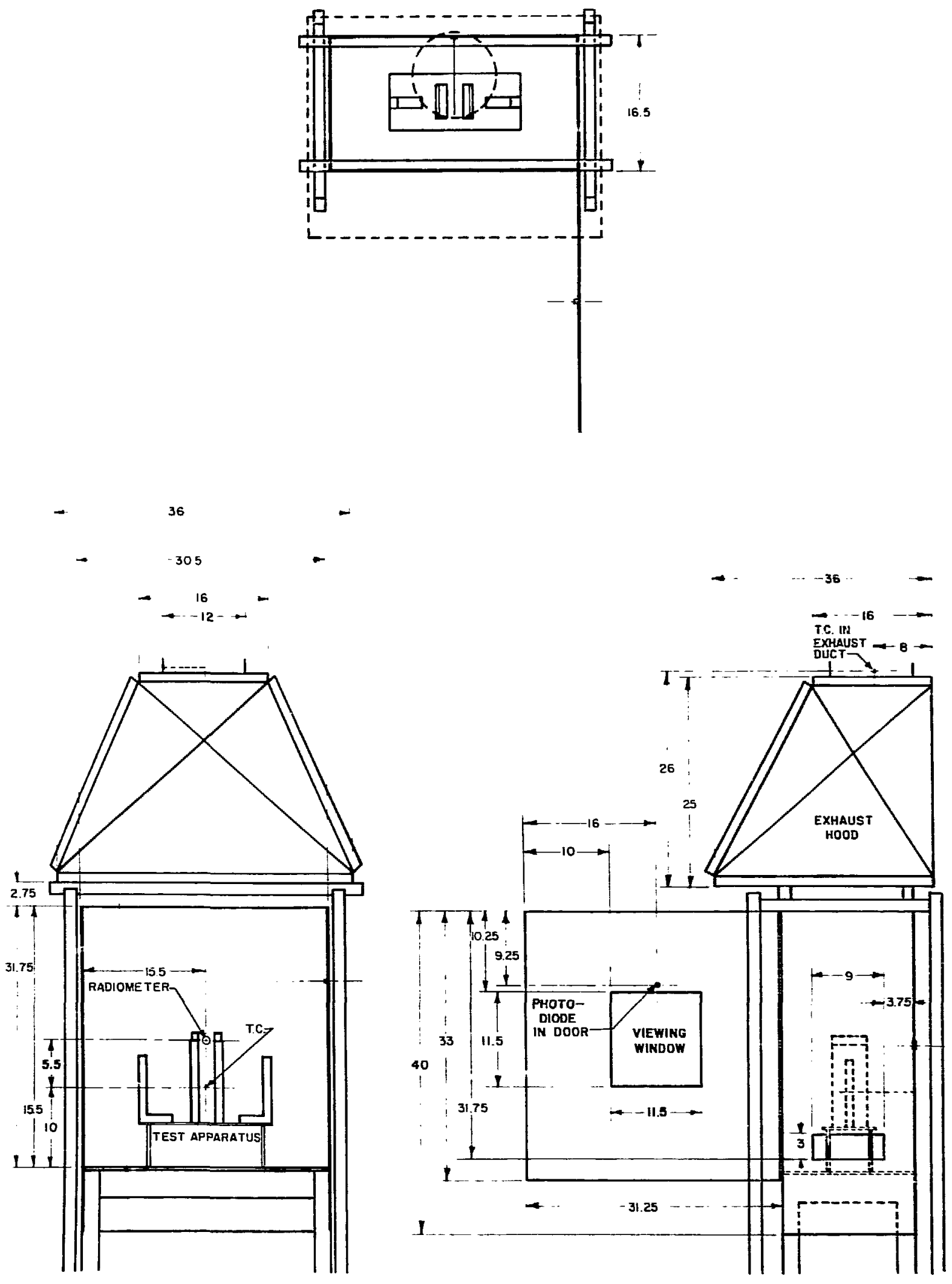

Figure 12. Schematic of ease-of-ignition apparatus. 


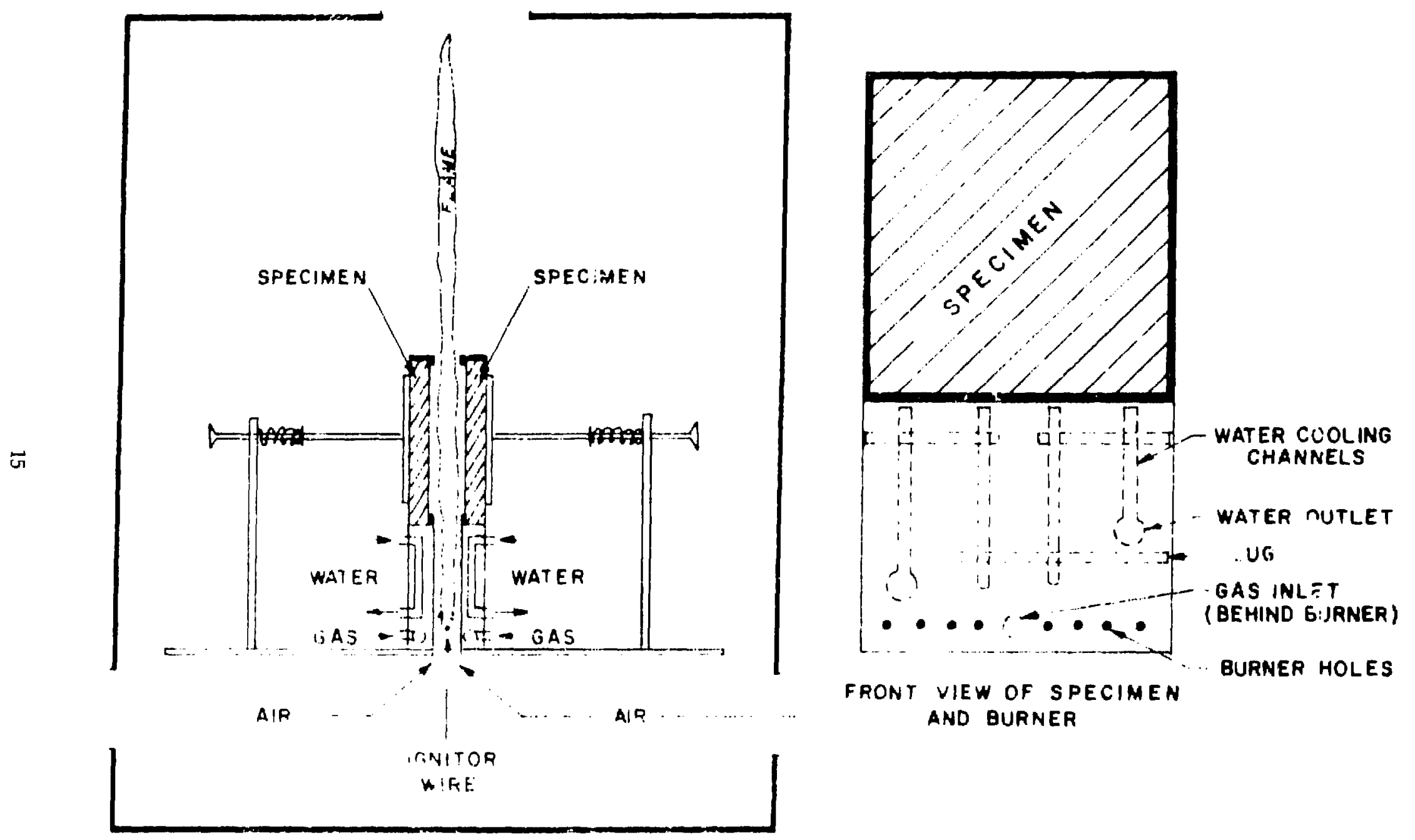

FRONT VIEW OF APPARATUS

Figure 13. Sketch of ease-of-ignition apparatus showing inlet and outlet ducts. 


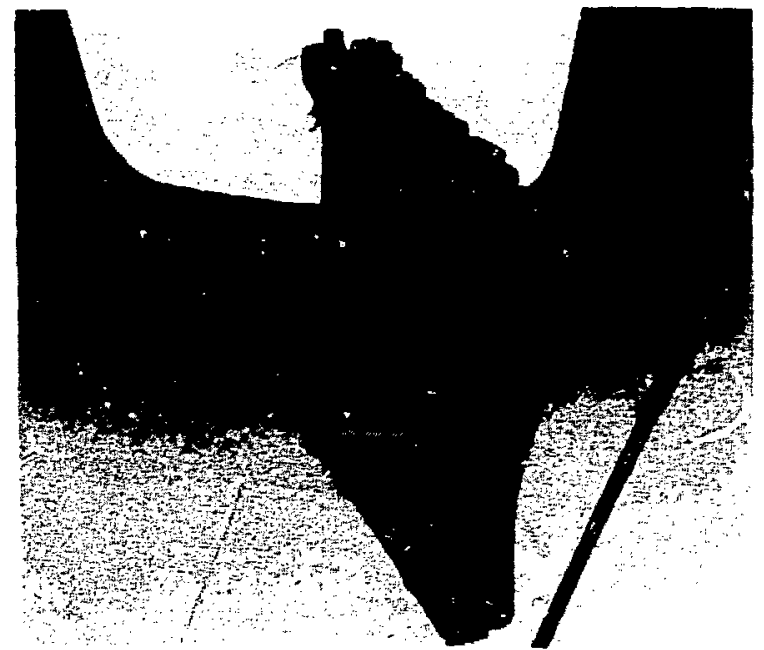

Figure 14. Specially designed cable specimen holder. There were two specimens for earh iest and we conducted four tests.

holders gripped cable samples at their ends (Fig. 14), ard this provided sufficient tension to prevent deformation of the individual cables due to heating, which ensured reasonable reproducibility among all samples. Two inert specimens of the same dimensions were prepared from 12.7mm-thick calcium silicate board stock. These blank specimens were used for determining the temperature baseline and for preheating.

\section{Test Apparatus Specifications}

The specifications listed below were the baseline parameters for conducting our standard easeof-ignition test5.

\section{Gas Flow}

The gas-flow rate through each of the independently controlled burners was set to approxi- mately $100 \mathrm{~cm}^{3} / \mathrm{s}(12.5 \mathrm{SCFH})$ of technical-grade methane producing a heat flux of $3.2 \mathrm{~W} / \mathrm{cm}^{2} \pm$ $0.2 \mathrm{~W} / \mathrm{cm}^{2}$ from a total gas flow of $200 \mathrm{~cm}^{3} / \mathrm{s} \pm$ $10 \mathrm{~cm}^{3} / \mathrm{s}$ ( $25 \mathrm{SCFH} \pm 1.3 \mathrm{SCFH}$ ) that resulted in an energy release of about $7 \mathrm{~kJ} / \mathrm{s}$.

\section{Test Procedure}

At the beginning of each test day, cooling water was turned on to a predetermined flow rate and the hood draft was turned on. Two pieces of miranite were mounted in the test flame, the data acquisition system was started, the electrical spark igniter was turned on, and the solenoid gas valves were opened. The box was preheated for $60 \mathrm{~s}$, which provided the baseline thermopile output for the day's testing. After this period, the burners were shut off, the miranite boards were replaced by actual samples, and formal testing begun.

The time to flame attachment (visual) was noted with a time marker on a strip-chart recorder. Generally, just before the time that flame attachment was noted, the thermopile voltage increased, indicating the onset of fuel contribution. The time to fuel contribution was picked from the recorder trace as the time at which the trace began to rise above the baseline, as determined by a straight-line projection of the rising part of the thermopile trace back to the baseline. Small increases in thermopile voltage of less than $10 \%$ of the baseline were ignored.

The test was terminated three seconds or more after (1) the trace either exceeded the baseline by $30 \%$ or a maximum temperature had been reached, and (2) a flame attachment had occurred. Otherwise, it was continued for a total duration of five minutes. We conducted four tests of each cable type.

Table 4 lists physical descriptions of the six cable types tested thus far. There is a variety of sizes and material combinations. Figures 15 and 16 are exemplar plots of thermopile and photodiode outputs. Table 5 lists the mean times to fuel

Table 4. Physical characteristics of cables tested during FY 82.

\begin{tabular}{|c|c|c|c|c|c|}
\hline Cable & $\begin{array}{l}\text { o.d. } \\
(\mathrm{mm})\end{array}$ & $\begin{array}{l}\text { Circumference } \\
(\mathrm{mm})\end{array}$ & $\begin{array}{c}\text { Jacket } \\
\text { thickness } \\
\text { (mm) }\end{array}$ & $\begin{array}{c}\text { Time to ignition } \\
\text { (s) }\end{array}$ & $\begin{array}{c}\text { Dielectric } \\
\text { jacket } \\
\text { materials }\end{array}$ \\
\hline 95 & 7.6 & 23.9 & 11.7 & 11.7 & $\begin{array}{l}\text { polyethylene, PVC, } \\
\text { multiconductor }\end{array}$ \\
\hline 12 & 3.7 & 11.2 & 1.6 & 67.3 & rubber \\
\hline 3 & 5.6 & 17.5 & 0.79 & 75.0 & PVC, nylon \\
\hline 007 & 22.9 & 71.9 & 3.9 & 83.2 & rubber or Neoprene \\
\hline 104 & 10.3 & 32.3 & 0.79 & 126.4 & polyethylene, PVC \\
\hline RG $11 \mathrm{~A} / \mathrm{U}$ & 10.3 & 32.3 & $: ?$ & 150.2 & polyethylene, PVC \\
\hline
\end{tabular}




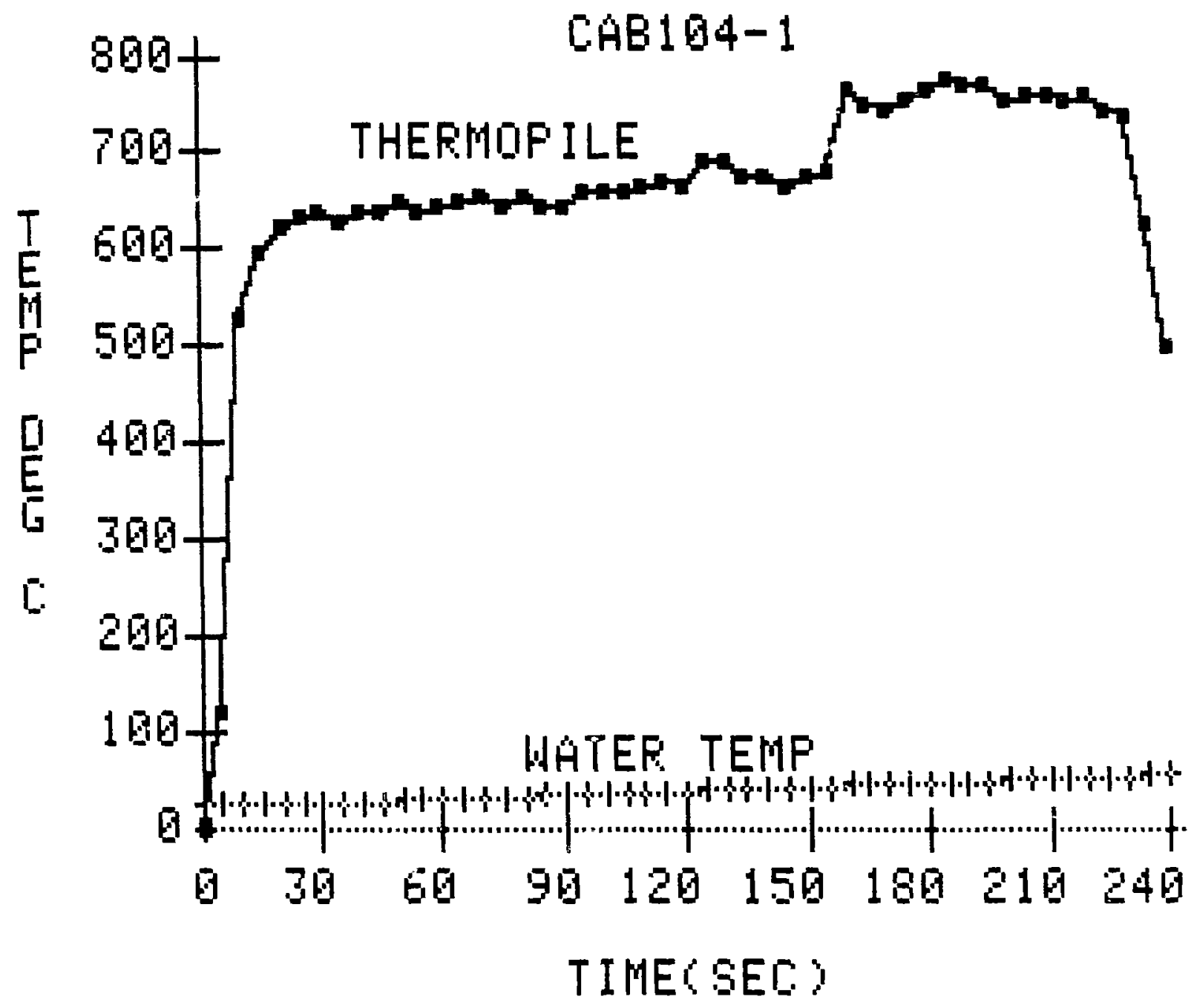

Figure 15. Exemplar plots of Cable-104 test (thermopile).

contribution and the coefficient of variation for each group of four replications. In addition, each of the cable types is ranked in ascending order of time to ignition.

\section{Results}

Several facts become apparent upon analysis of the data. The most obvious fact is the wide spread in ignition times as indicated by the coefficient of variation. Because we performed only four replications of earh cable type, one anomalous run had a significant effect on the standard deviation for the time. to ignition of a given cable type. Considering the many variables in both the experimental apparatus and the test specimens (change in configuration due to deformation of individual cables), this variation is not surprising.

More importantly, more cable types must be tested to evaluate the individual effects of cable size, geometry, composition, and materials on ignitability. It can be seen from the ranking of the data in Table 5 that both size and jacket material have significant influences. Figures $17(a)$ and (b) illustrate the variety of cable types and sizes tested thus far. Furthermore, for this scale experiment, the outer jacket thickness should account for the ease or resistance to ignition. Referring to Table 5, we see that although cable 95 has an o.d. of $7.6 \mathrm{~mm}$, it has the shortest time to ignition at $11.7 \mathrm{~s}$. This may be because it is a multiconductor cable with a polyethylene outer jacketing. On the other hand, cable 007, which has more than twice 


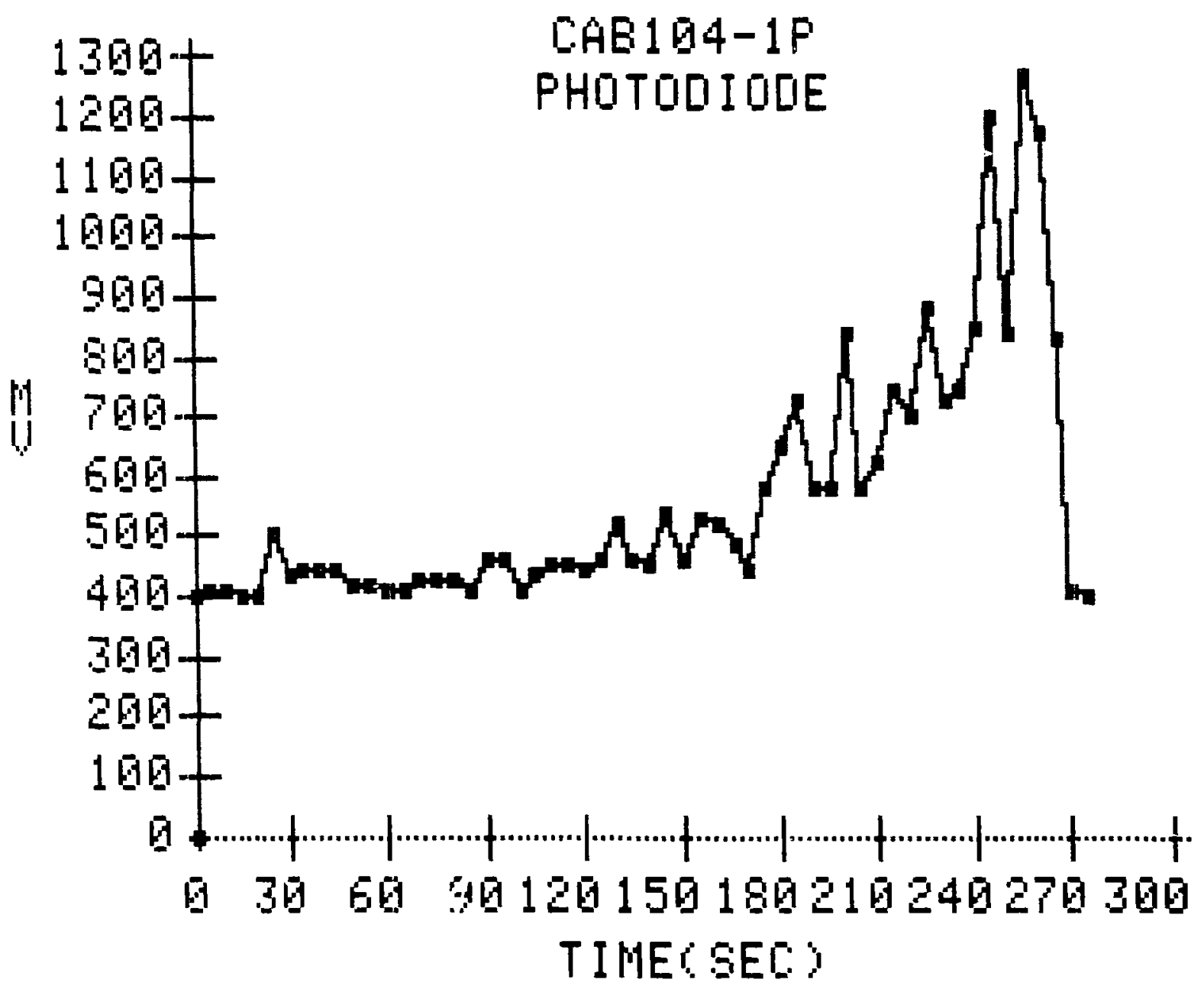

Figure 16. Exemplar plots of Cable-104 test (photodiode).

Table 5. Ease-of-ignition experiment results (series 1). The cables are listed in order of increasing times to ignition (example: Cable 95 is the easiest to ignite and RG 11 is the most difficult to ignite).

\begin{tabular}{lcc}
\hline \multicolumn{1}{c}{$\begin{array}{c}\text { Cable } \\
\text { type }\end{array}$} & $\begin{array}{c}\text { Mean time } \\
\text { to fuel } \\
\text { contribution } \\
\text { (sec) }\end{array}$ & $\begin{array}{c}\text { Coefficient } \\
\text { of variation } \\
(\%)\end{array}$ \\
\hline $\begin{array}{l}\text { Cable 95 } \\
\text { (polyethylene) } \\
\text { Cable 12 } \\
\text { (rubber) }\end{array}$ & 11.7 & 31.2 \\
$\begin{array}{l}\text { Cable 3 } \\
\text { (PVC) }\end{array}$ & 67.3 & 10.7 \\
$\begin{array}{l}\text { Cable 007 } \\
\text { (rubber or }\end{array}$ & 75.0 & 43 \\
$\begin{array}{l}\text { Neoprene) } \\
\text { Cable 104 } \\
\text { (PVC) } \\
\text { RG 11 A /U } \\
\text { (PVC) }\end{array}$ & 83.2 & 7 \\
\hline
\end{tabular}

the diameter of the next largest cable, falls to a median position in the ranking.

In an attempt to evaluate some of these size and geometric effects, we used several quasinormalization techniques; these results are presented in Table 6. By comparing the rankings obtained through these manipulations to the actual experimental times to ignition, we should be able to theorize which physical or chemical cable properties cause better or worse fire performance. In other words, when the time to ignition is modified by any of the size parameters, the cable order by increasing difficulty of ignition changes depending upon which relationship is used. For example. cable 12 has the second shortest experimental time to ignition, and is ranked best and second best by three of the four techniques; it also is difficult to ignite relative to its size. ln order to determine the change in performance due to the jacket material or the conductor configuration (i.e., multiconductor, stranded, solid, etc.), other cable types of different jacket materials but of the same 

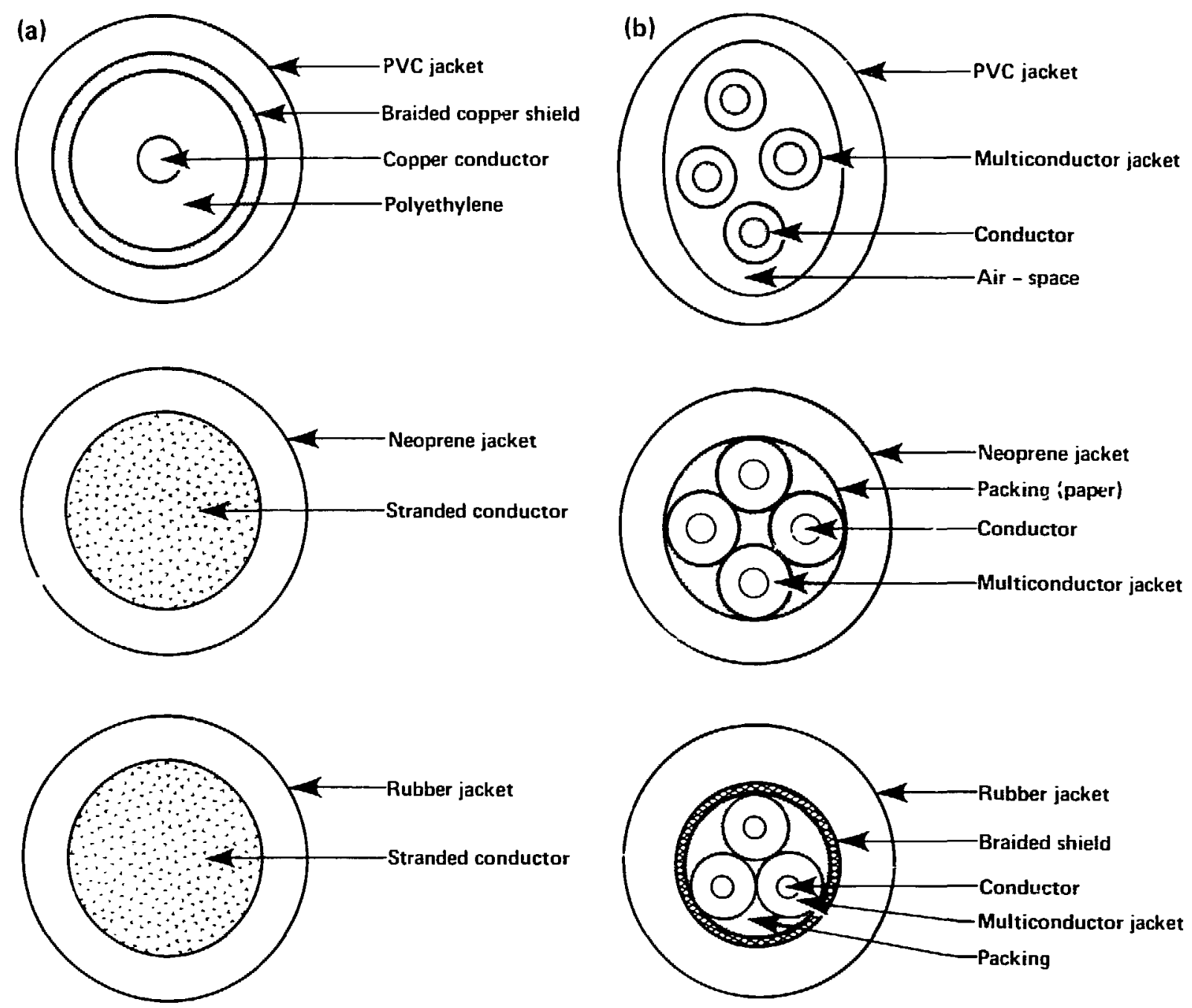

Figure 17. Cross sections of (a) single conductor cables and (b) multiconductor cables.

size could be identified and tested. We will follow this through in FY 83, and we will attempt to use these results to predict a cable type's relative ease of ignition without having to test it. We will also look at ways to modify the apparatus, thus improving its reproducibility.

Table 5. Time-to-ignition (TTI) rates of various cables. Numbers in parentheses denote ranking of the cables according to the times to ignition of each one, with $1=$ shortest time to ignition and $6=$ longest time to ignition.

\begin{tabular}{lcccc}
\hline \multicolumn{1}{c}{ Cable } & $\begin{array}{c}\text { Time to ignition } \\
\text { (s) }\end{array}$ & $\begin{array}{c}\text { TTl/o.d. } \\
\text { (s) }\end{array}$ & $\begin{array}{c}\text { TTI/circum/jacket } \\
\text { (s) }\end{array}$ & $\begin{array}{c}\text { TTl/jacket/o.d. } \\
\text { (s) }\end{array}$ \\
\hline 95 & $11.7(1)$ & $39(1)$ & $0.385(1)$ & $113.6(1)$ \\
007 & $83.2(4)$ & $92(2)$ & $4.59(4)$ & $153.7(2)$ \\
104 & $126.4(5)$ & $312(3)$ & $3.09(2)$ & $531.9(4)$ \\
3 & $75.0(3)$ & $341(4)$ & $3.37(3)$ & $480.9(3)$ \\
RG 11 A/U & $150.2(6)$ & $371(5)$ & $5.56(5)$ & $1641.6(6)$ \\
12 & $67.3(2)$ & $467(6)$ & $9.64(6)$ & $1294.8(5)$ \\
\hline
\end{tabular}




\section{Fire Modeling}

As part of our ongoing program to create a versatile model for enclocure fires in order to assist us in fire-risk assessment, we conducted another series of idealized enclosure fires in the LLNL fire test cell. Goals of these tests included:

- Evaluating and ratifying fire models for enclosures served by HVAC systems where air pumps provide negative pressure in the enclosure;

- Determining enclosure and ventilation properties that control fire output parameters;

- Determining the heat transfer from forced-ventilation enclosure fires to enclosure gases, enclosure surfaces, exit ventilation systems and exit gases;

- Determining the ceiling-layer descent velocity and level for such fires;

- Determining the density of combustion aerosols in the vertical plume and ceiling jer;

- Relating fire-plume heights to heatrelease rate and fire dimensions;

- Measuring radiative heat to and from the fire source or second fuel source; and

- Determining fire characteristics that affect the inlet ventilation and aeration of the fire in a forced-ventilation enclosure.

Tests conducted during FY 81 (the first set of ideal model test fires) were useful as preliminary data sources for model validation, and they provided us with practical experience. Extensive data analysis revealed the following problems encountered during this series:

- Ventilation analysis indicated that too much air escapes from the inlet directly to the outlet.

- There were problems with rake stability. There were only 10 thermocouples and the thermocouple plane varied from the design positions from test to test.

- Water vapor was not removed before entrance into gas analyzers.

- Methane tests used a float rotometer which was not methane-calibrated nor was its temperature and pressure measured during tests.

- There were no pre-fire or post-fire baseline data.

- The fire duration was short and no tests to quasi-equilibrium were conducted.

During the planning for FY 82 experiments, these problems were rectified, and, in addition, we implemented the following improvements and modifications during FY 82:

(1) We conducted more varied tests (31 in all with wider fuel geometries and types). We also conducted some pool fires.
(2) We improved the input ventilation to promote low-air release and mixed conditions before reaching the exit duct. We added 2 rakes with 15 thermocouples each and a rigid support with provisions for thermal expansion. We added water traps in the gas-sample lines. We added a critical orifice and a turbine flowmeter for gasfuel metering, both of which are temperaturecompensated and pressure-recorded.

(3) We sampled high and low gases in the cell as well as the gases in the duct. We made more thermal measurements (heat transfer) and wall-temperature measurements.

Table 7 lists the experiments we conducted during FY 82. We include information on the type of fire, and the heat-release rate and forcedventilation rate of the design.

The type of fire depended upon the fuel phase and method of fuel control. In the tests using "burner," pure methane, metered by a critical orifice and turbine meter, was conveyed to a $0.28-\mathrm{m}$ diameter rock-filled pan. Gas entering the pan bottom distributed uniformly' through the rock bed to form a jet above rock bed surface.

Fire types that we designated "spray" had liquid fuel flow from a pressurized reservoir through a previously calibrated rotometer to an opposed jet nozzle located in the center of a $0.91-\mathrm{m}$ diameter steel pan. Liquid from the nozzle was sprayed on a plane normal to the orifice axis in a radial distribution. We ignited it remotely by an energized electric arc; the atomized spray was quickly evaporated and hurned before it contacted pan surfaces. The resulting fire had every appearance of a natural pool fire. Figure 18(a) shows the opposed jet nozzle, (b) the jet in the $0.91-\mathrm{m}$ pan, (c) the jet nozzle spray pattern, and (d) a spraytype fire.

Pool fires were contained in the $0.91-\mathrm{m}$ pan. We defined the heights of fuel so that the pan edges did not influence the burning rate."

Wt ran several tests either as preliminary "shake donn" experiments. or as insurance tests. We conducted these experiments in the fire-test cell described in previous reports. ${ }^{3}$ Because the modeling of these data was to be performed by several external agencies, detailed schematics of the test-cell geometry and instrumentation were prepared and distributed to interested individuals. ${ }^{7}$ Figure 19 shows sectional-cell and exit-duct dimensions for the case where test-cell extraction is from the high $(3.6 \mathrm{~m})$ exit air opening. Figure 20 , a:l exploded view of the test cell, shows the placement of air temperature and heat transfer-sensors. 
Table 7. F` 82 fire test experiments.

\begin{tabular}{|c|c|c|c|c|c|}
\hline \multirow{2}{*}{$\frac{\text { Test }}{1}$} & \multirow{2}{*}{$-\frac{\text { Type }}{\text { Burner }}$} & \multicolumn{2}{|c|}{ Tuel and formula } & \multirow{2}{*}{$\frac{\begin{array}{c}\dot{Q} \\
(\mathrm{kWV})\end{array}}{125}$} & \multirow{2}{*}{$\begin{array}{c}V \\
(1 / s) \\
250\end{array}$} \\
\hline & & Methane & $\mathrm{CH}_{3}$ & & \\
\hline 2 & Burner & Methane & $\mathrm{CH}_{4}$ & 50 & 500 \\
\hline 3 & Buither & Methane & $\mathrm{CH}_{4}$ & 50 & 100 \\
\hline 4 & Burner & Methane & $\mathrm{CH}_{4}$ & 200 & 100 \\
\hline 5 & Burner & Methane & $\mathrm{CH}_{4}$ & 400 & 500 \\
\hline 6 & Burner & Methane & $\mathrm{CH}_{4}$ & 400 & 100 \\
\hline 7 & Burner & Methane & $\mathrm{CH}_{4}$ & 125 & 250 \\
\hline 8 & Spray & Isopropanol & $\mathrm{C}_{3} \mathrm{H}_{5} \mathrm{O}$ & 400 & 500 \\
\hline 9 & Spray & Isopropanol & $\mathrm{C}_{3} \mathrm{H}_{8} \mathrm{O}$ & 800 & 500 \\
\hline 10 & Spray & Isopropanol & $\mathrm{C}_{3} \mathrm{H}_{8} \mathrm{O}$ & 100 & 100 \\
\hline 11 & Spray & Isopropanol & $\mathrm{C}_{3} \mathrm{H}_{8} \mathrm{O}$ & 100 & 500 \\
\hline 12 & Spray & Isopropanol & $\mathrm{C}_{3} \mathrm{H}_{4} \mathrm{O}$ & 800 & 100 \\
\hline 13 & Spray & Isopropanol & $\mathrm{C}_{3} \mathrm{H}_{2} \mathrm{O}$ & 400 & 500 \\
\hline 14 & Spray & Isou:tane & $\mathrm{C}_{6} \mathrm{H}_{16}$ & 409 & 500 \\
\hline 15 & Spray & Isooctane & $\mathrm{C}_{\mathrm{H}} \mathrm{H}_{\mathrm{lB}}$ & 800 & 500 \\
\hline 16 & Spray & Isooctane & $\mathrm{C}_{9} \mathrm{H}_{3, k}$ & 800 & 100 \\
\hline 17 & Pool & Isoprupanol & $\mathrm{C}_{3} \mathrm{H}_{6} \mathrm{O}$ & $0.91 \mathrm{rn}$ & 500 \\
\hline 18 & Pool & Isopropanol & $\mathrm{C}_{3} \mathrm{H}_{3} \mathrm{O}$ & $0.91 \mathrm{~m}$ & 100 \\
\hline 19 & Pool & Isqoctane & $\mathrm{C}_{\mathrm{R}} \mathrm{H}_{1 \mathrm{~B}}$ & $0.41 \mathrm{~m}$ & 500 \\
\hline 20 & Pool & Polystyrene & $\left(\mathrm{C}_{8} \mathrm{H}_{0}\right)_{\mathrm{n}}$ & $0.91 \mathrm{~m}$ & 500 \\
\hline $23^{4}$ & Spray & Isooctane & $\mathrm{C}_{8} \mathrm{H}_{18}$ & 400 & 100 \\
\hline 24 & Spray & Isooctane & $\mathrm{C}_{8} \mathrm{H}_{13}$ & 2.30 & 100 \\
\hline 25 & Spray & Isopropanol & $\mathrm{C}_{3} \mathrm{H}_{8} \mathrm{O}$ & 200 & 10u \\
\hline 26 & Spray & Isopropanol & $\mathrm{C}_{3} \mathrm{H}_{8} \mathrm{O}$ & 400 & 100 \\
\hline $2 ?$ & Spray & lsopropanol & $\mathrm{C}_{3} \mathrm{H}_{6} \mathrm{O}$ & 400 & 250 \\
\hline
\end{tabular}

Tests 21 and 22 were cancelled.
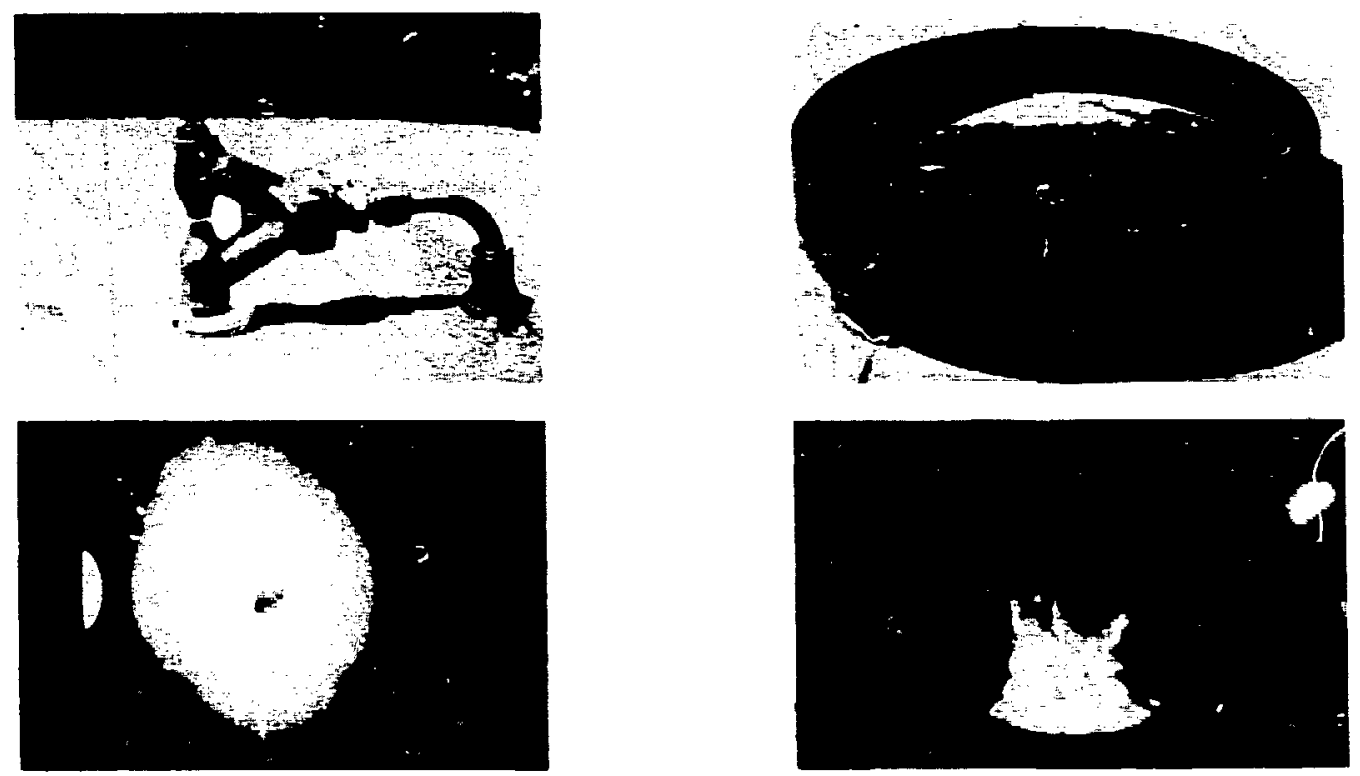

Figure 18. Detail of typical spray-type fire test. Photos show the (a) opposec jet nozzle, (b) jet in the $0.91 \mathrm{~m}$ pan, (c) nozzle jet-spray pattern, and (d) a spray-type fire. 


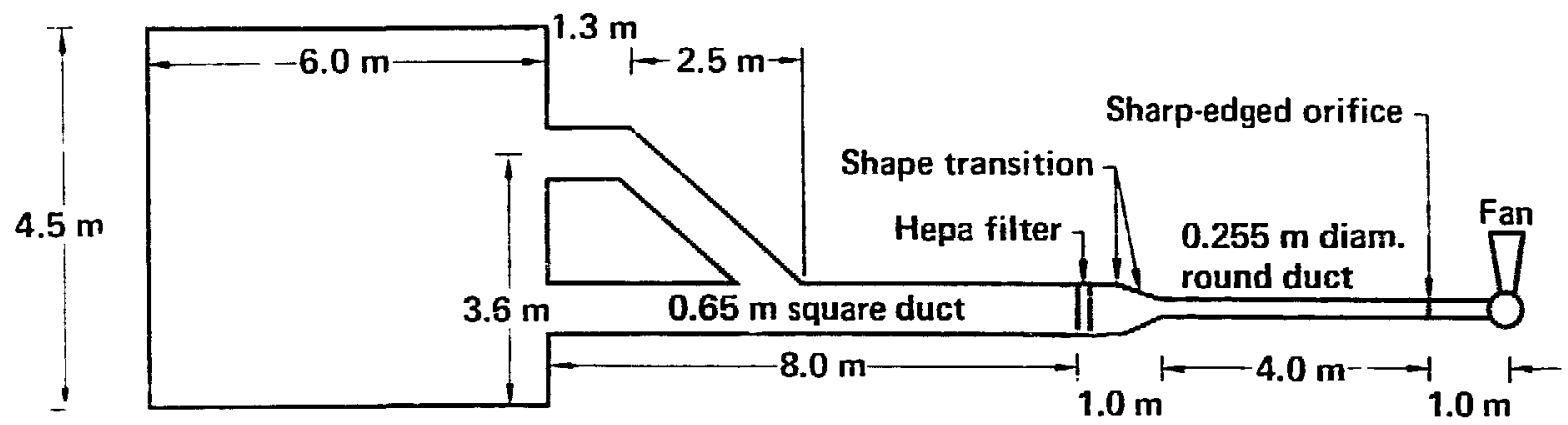

Figure 19. Test cell and exit duct dimensions (vertical section).

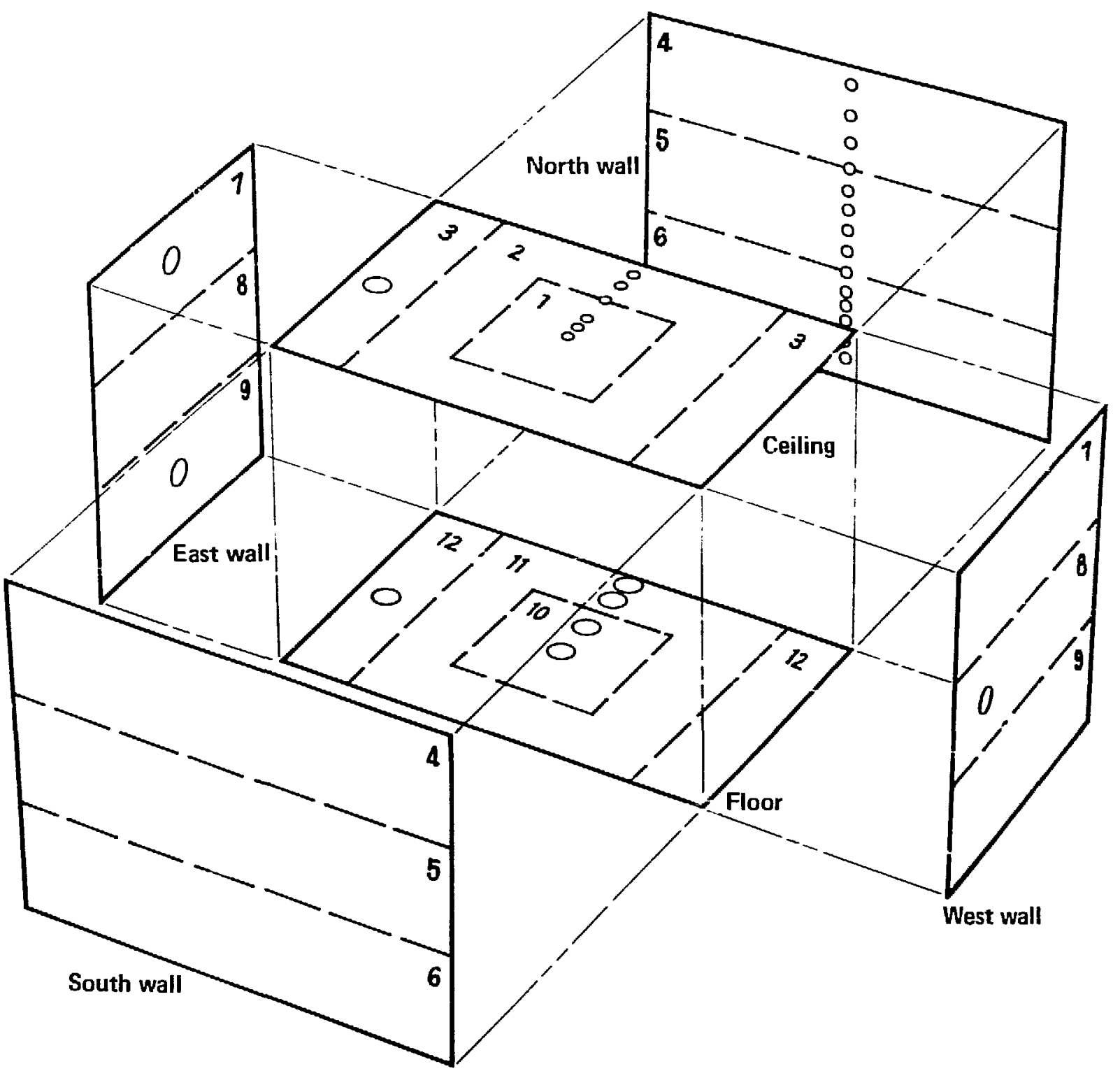

Figure 20. Blow-up representation of cell showing thermocouple locations and marked surface zones. 
FY 81 measurements indicated that mist of the conibustion energy is absorbed in enclosure surfaces (up to $80 \%$ ). To ascertain the distributisn of surface energy deposition, we installed thermocouples on test cell surfaces in the array shown in Fig. 20. We designed this array unter the assumption that thermal energy deposition is symmetrical in the test cell.

Figure 21 is a fire portrait illustrating some of the important data from a $400 \mathrm{~kW}$ isopropanol spray fire. ventilated at $250 \mathrm{l} / \mathrm{s}$. The curves and scales are as follows: $\mathrm{CO}_{2}, \mathrm{CO}$, and total hydrocarbon production on $0-12 \%$ scale, $\mathrm{O}_{2}$ production on $0-39 \%$ scale, exit-air flow, south-wall temperature, and entrance-to-duct temperature on 0-600 scale, and inlet airflow on -600 to +600 scale.

A typical characteristic of our forcedventilation enclosure tests is the reverse flow out of the inlet duct j'st after ignition. This reversal is caused by the sire rapidly expanding the room air and correlates directly with the rate of air temperature rise in the room. For large fires $(\dot{Q}>200 \mathrm{~kW})$ with a low ventilation rate, this effect is pronounced and causes flow reversal in the inlet duct, as indicated in Fig. 21.

Because enclosure surfaces are good insulators, the time to thermal equilibrium in the cell is extremely long. Both air- and surfacetemperature measurements indicated a rapid temperature rise during initial heatup of the cell, after which the rising temperature rates wie greatly reduced and appeared to be approaching equilibrium. Note that air temperature is larger than wall temperature, but this difference is small, which indicates that substantial thermal energy is given up to the vills.

Measurements of oxygen depletion and generation of combustion products show complementary patterns of special production, reaching maximum levels which then decrease slightly prior to termination of the test. This behavior may have resulted from internal-balance mechanisms where over-shoot in combustion equilibrium was rectified by transport processes.

Figure 22 shows two fire portraits that contrast thermal, combustion, and flow parameters between fires of high and low fire strengths at the same $500 \mathrm{l} / \mathrm{s}$ ventilation rate (Tests $9 \mathrm{~A}$ at $800 \mathrm{~kW}$ and $11 \mathrm{~A}$ at $100 \mathrm{~kW}$ ).* The effects of inadequate ventilation are replete in Test $9 \mathrm{~A}$ : large production of unburned hydrocarbon, high $\mathrm{CO}$ production,

\footnotetext{
- Scale ranges are the same for all fire portraits included in this section of the report as in Fig. 21.
}

and gas temperature peak and decrease. While in Test $11 \mathrm{~A}$, the same iuncions attain quasiequilibrium condition.

Figure 23 compares the effect of fuel type on thermal, chemical, and ventilation flow resultc for $400-\mathrm{kW}$ fires ventilaicd at $500 \mathrm{l} / \mathrm{s}$. Tests 5,13 and 14 used methane $\left(\mathrm{CH}_{4}\right)$, isopropanol $\left(\mathrm{C}_{3} \mathrm{H}_{5} \mathrm{O}\right)$, and isooctane $\left(\mathrm{C}_{8} \mathrm{H}_{13}\right)$ as fuel. Even though the design thermal output and ventilation rate were the same, all measured parameters appeared different for each fuel. Close inspection showed that the maximum values of temperature rise, and $\mathrm{CO}_{3}$ formation for the two liquid fuels are essentially the same. Oxygen depletion is different in ail cases and both the otal hydrocarbon and $\mathrm{CO}$ appear only for $\mathrm{CH}_{i}$ and $\mathrm{C}_{8} \mathrm{H}_{1}$. At this time, we cannot fully explain the difference between these data. One possible explanation relates to the methane fire where the combination of a highfuel flow and a small bumer diameter produced a turbulent momentum jet, not the buoyant plumes produced with the spray fires.

The four pool-fire tests we conducted during this series are shown in Fig. 24. Tests 17 and 18 show $\mathrm{C}_{3} \mathrm{H}_{8} \mathrm{O}$-pool fires at ventilation rates oi $500 \mathrm{l} / \mathrm{s}$ and $100 \mathrm{l} / \mathrm{s}$, respectively. Test 19 shows the $\mathrm{C}_{8} \mathrm{H}_{18}$ fire at a $500 \mathrm{l} / \mathrm{s}$ ventilation rate and Test 20 shows output from a polystyrene-bead pool fire at a $500 \mathrm{l} / \mathrm{s}$ ventilation rate. All the poul fires, except for Test 17, show extreme ventilation-control characteristics. Since these pools bum naturally, fuel consumption is directly dependent upon fireplume efficiency. Thus, output characteristics will reflect this efficiency. The obvious contrast between Test 17 and the other pool fires, regardless of the kind of fuel, is a good example of the different feedback response of well and poorly ventilated, naturally burning fires.

Figure 25 (combine rake data), which shows thermocouple output from rake* thermocouples for Test 8 , is a map of the temperatures recorded by alternate thermocouples. Air-temperature neasurements appeared to have established their distribution in about $300 \mathrm{~s}$. This observation is confirmed by noting the evolution of temperature profiles, shown in Fig. 26, at selected times early in the test. These data indicate that the profile is indeed well-formed by $300 \mathrm{~s}$ into the test. Figure 27 shows the temperature profile drawn by both east and west rakes aiter $1200 \mathrm{~s}$ of continuous burn. The profile shapes are very similar to

\footnotetext{
- Rake thermocouples located at east and west side of burn pan. Vertical array at one foot vertical increments.
} 


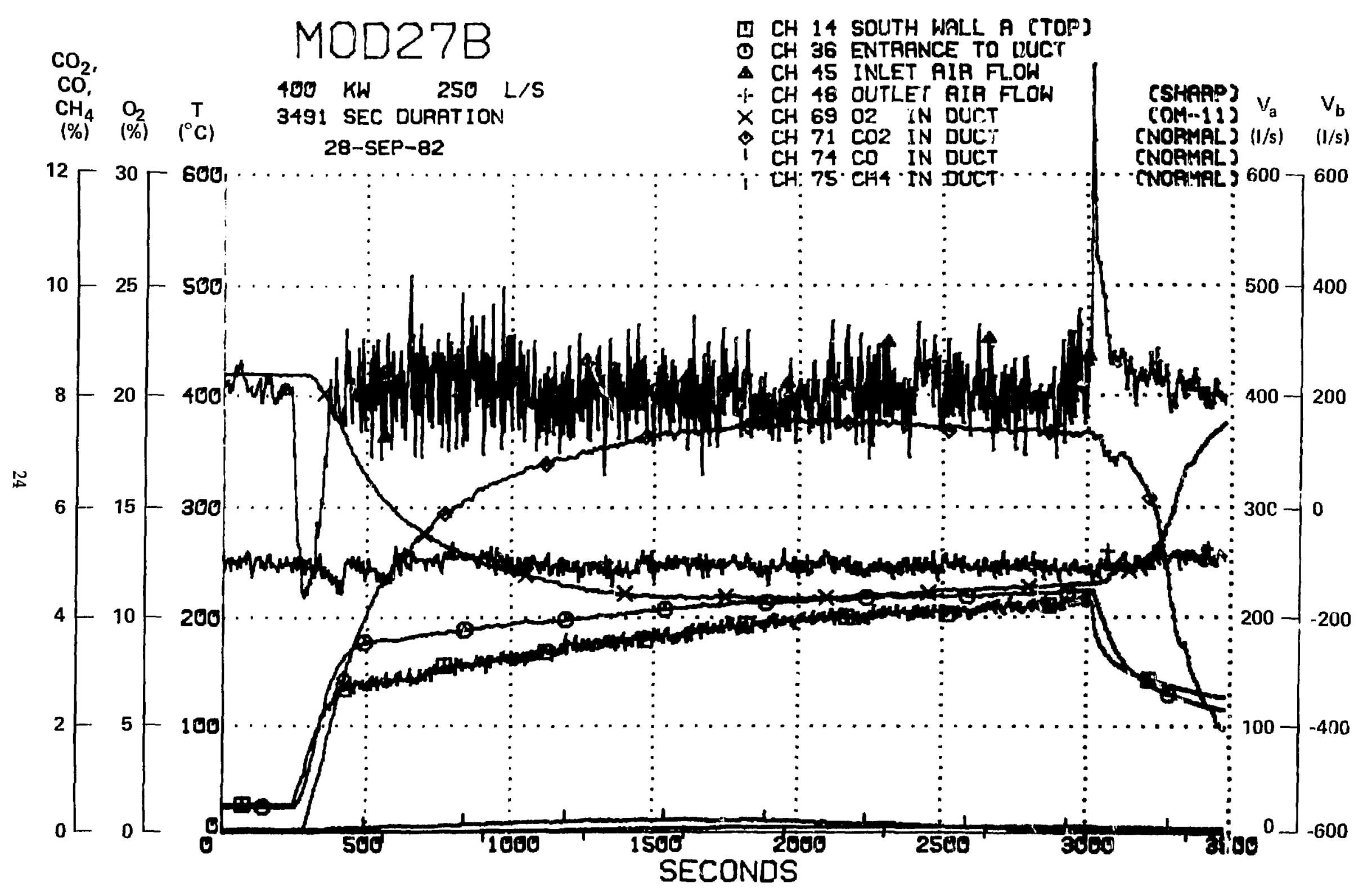

Figure 21. Modeling tests (Mod 27B) of a $400 \mathrm{~kW}$ fire that lasted over 58 minutes. The scale range is explained in the text $\left(\mathrm{V}_{\mathrm{a}}=\mathrm{outlet}_{\mathrm{i}}\right.$ flow $\mathrm{nnd}$ $\mathrm{V}_{\mathrm{b}}=$ inlet air flow, both in $1 / \mathrm{s}$ ). 

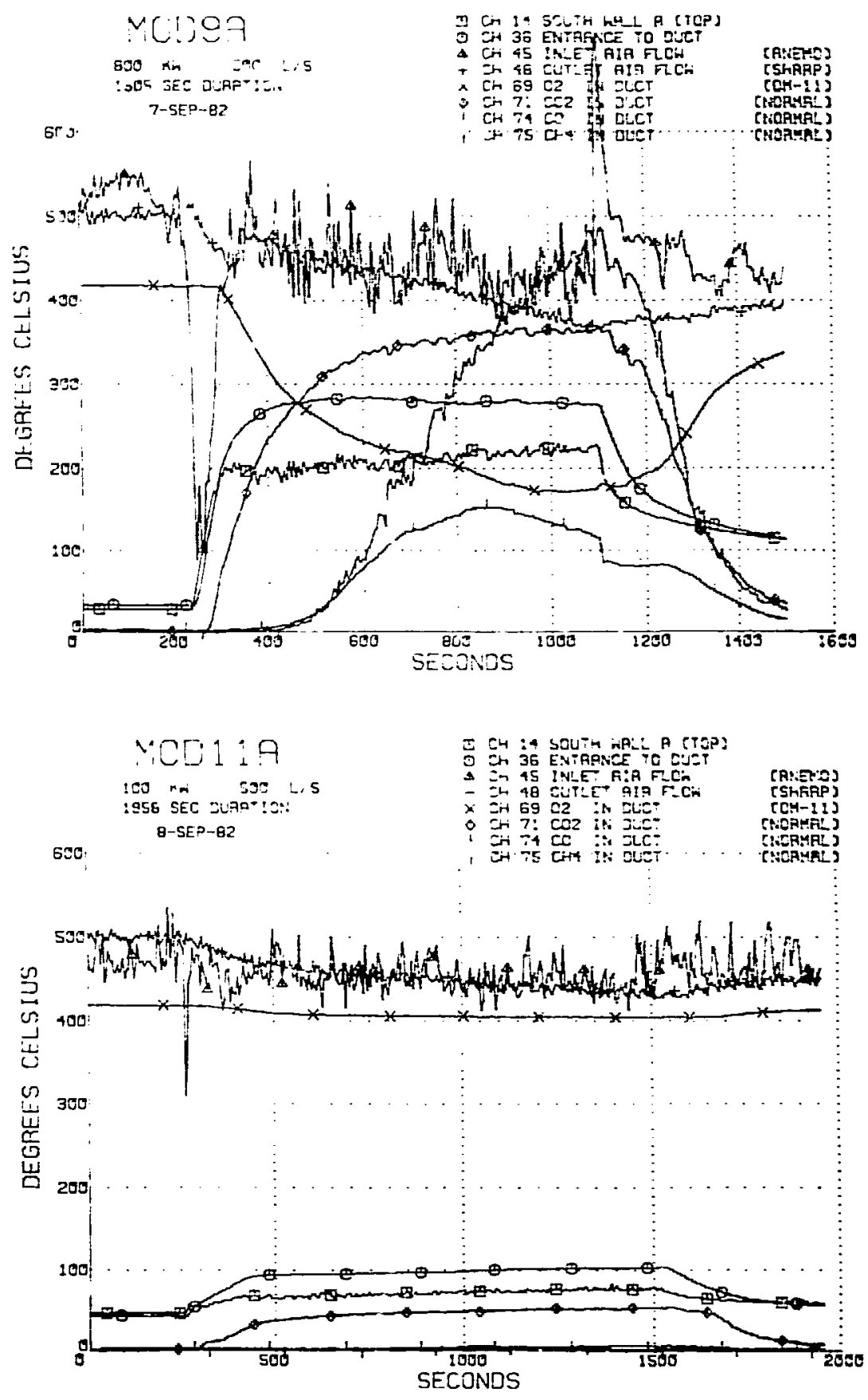

Figure 22. Mod 9A and Mod 11A.

that at $300 \mathrm{~s}$, except that most individuai temperature readings are about $50^{\circ} \mathrm{C}$ higher, as we would expect. The shape of tentperature profiles as shown in Figs. 26 and 27 is dependent upon the flow dynamics of the fire plume and entranceand exit-airflow patterns.

Most fire models predict that a fire will produce stratified flow conditions in a room that can be represented by a hot and cold layer of air separated by au interface. We choose to apoly Steckler's conservation technique ${ }^{k}$ to our temperature profiles in order to represent them in the two-layer condition used by some models. Results from this procedure are shown in Fig. 28 for both east and west rakes and the average calculated profile of both rakes. 

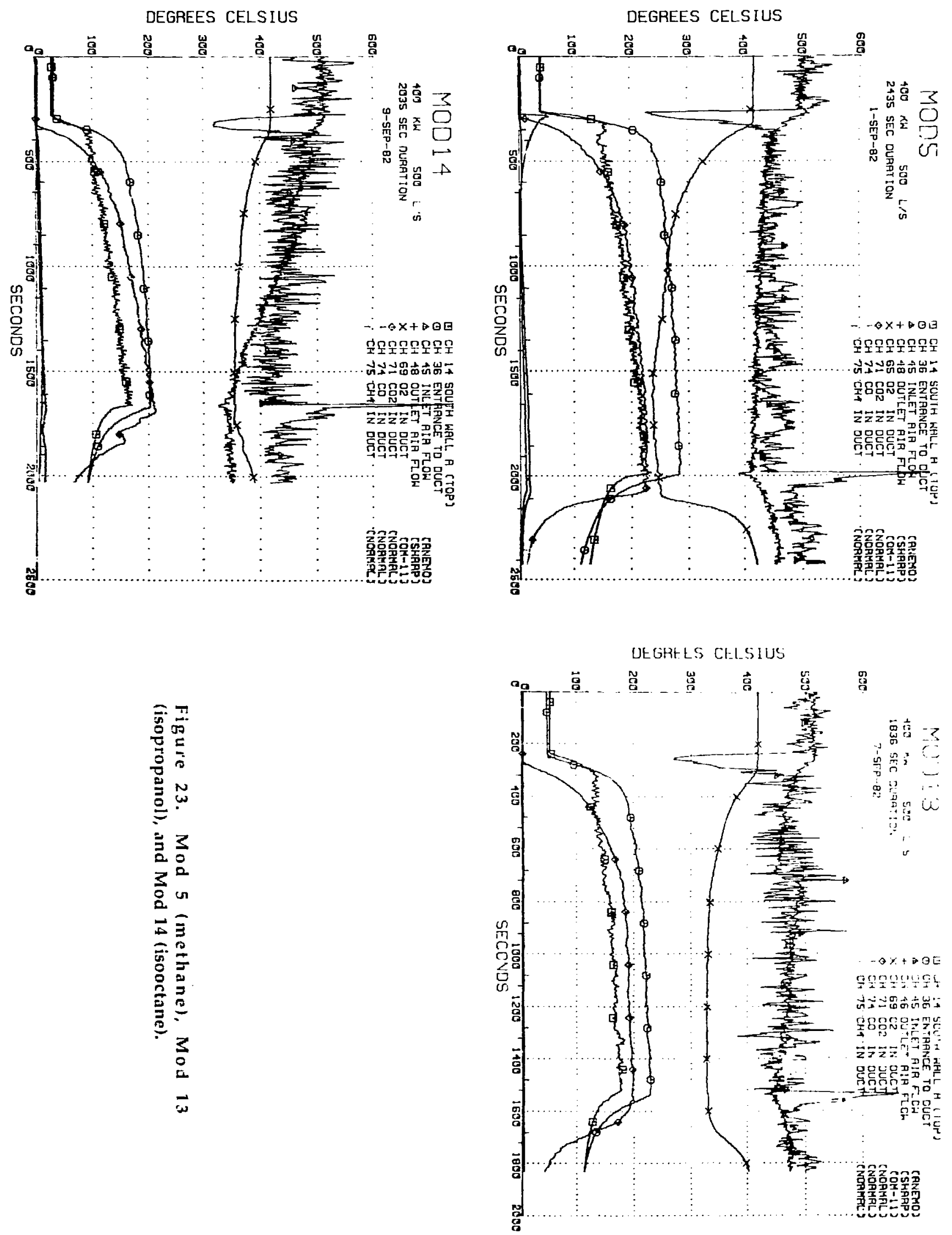

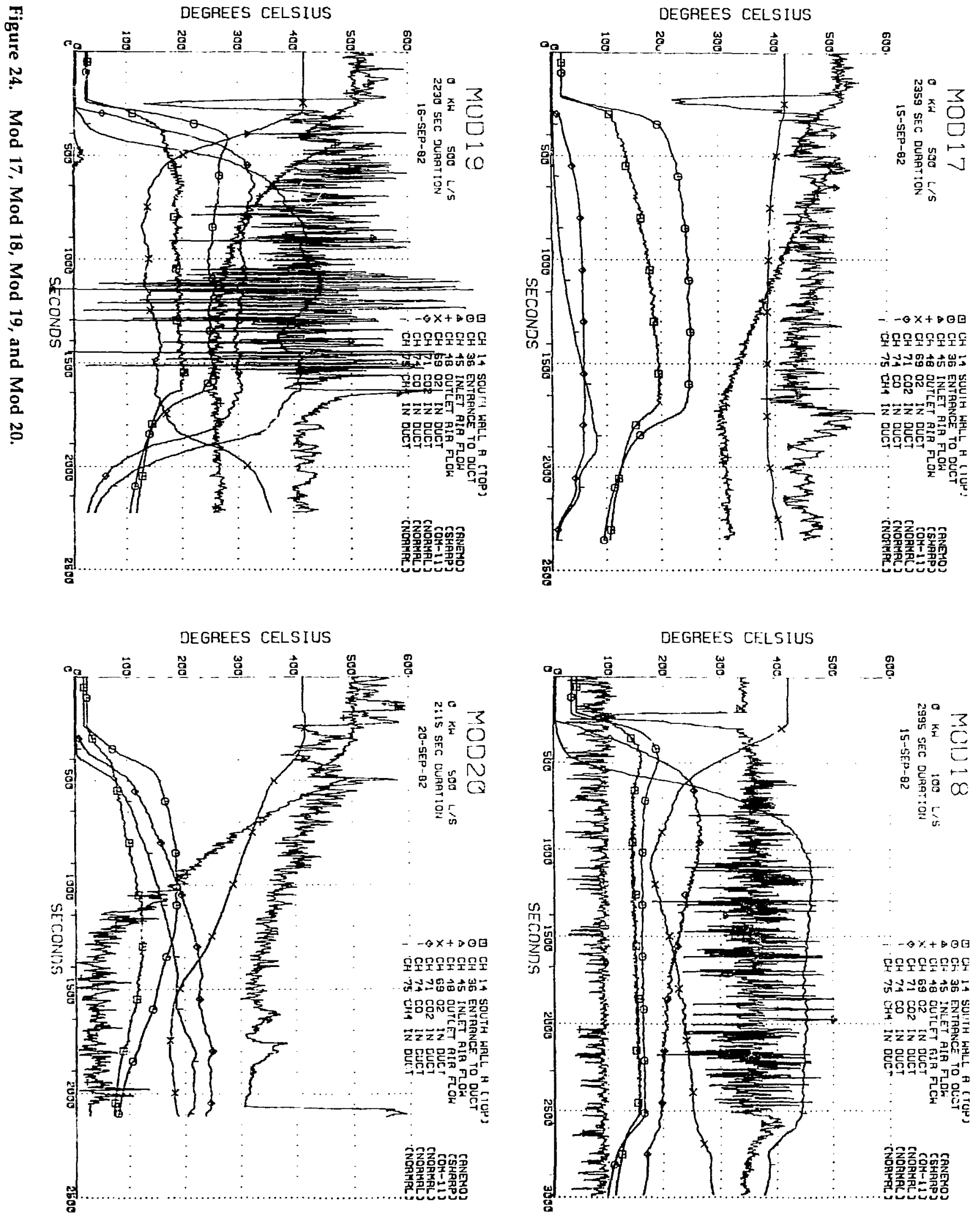


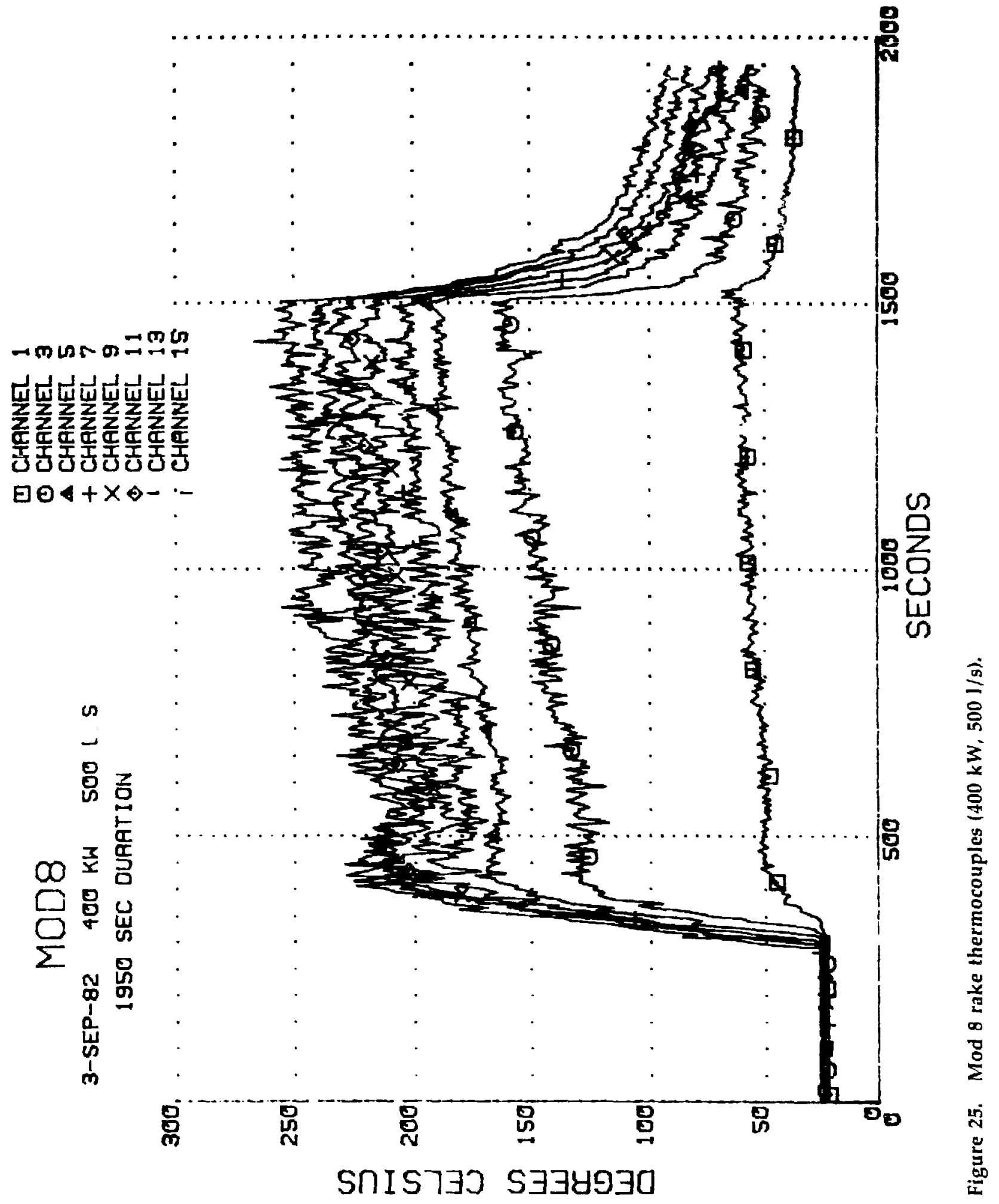




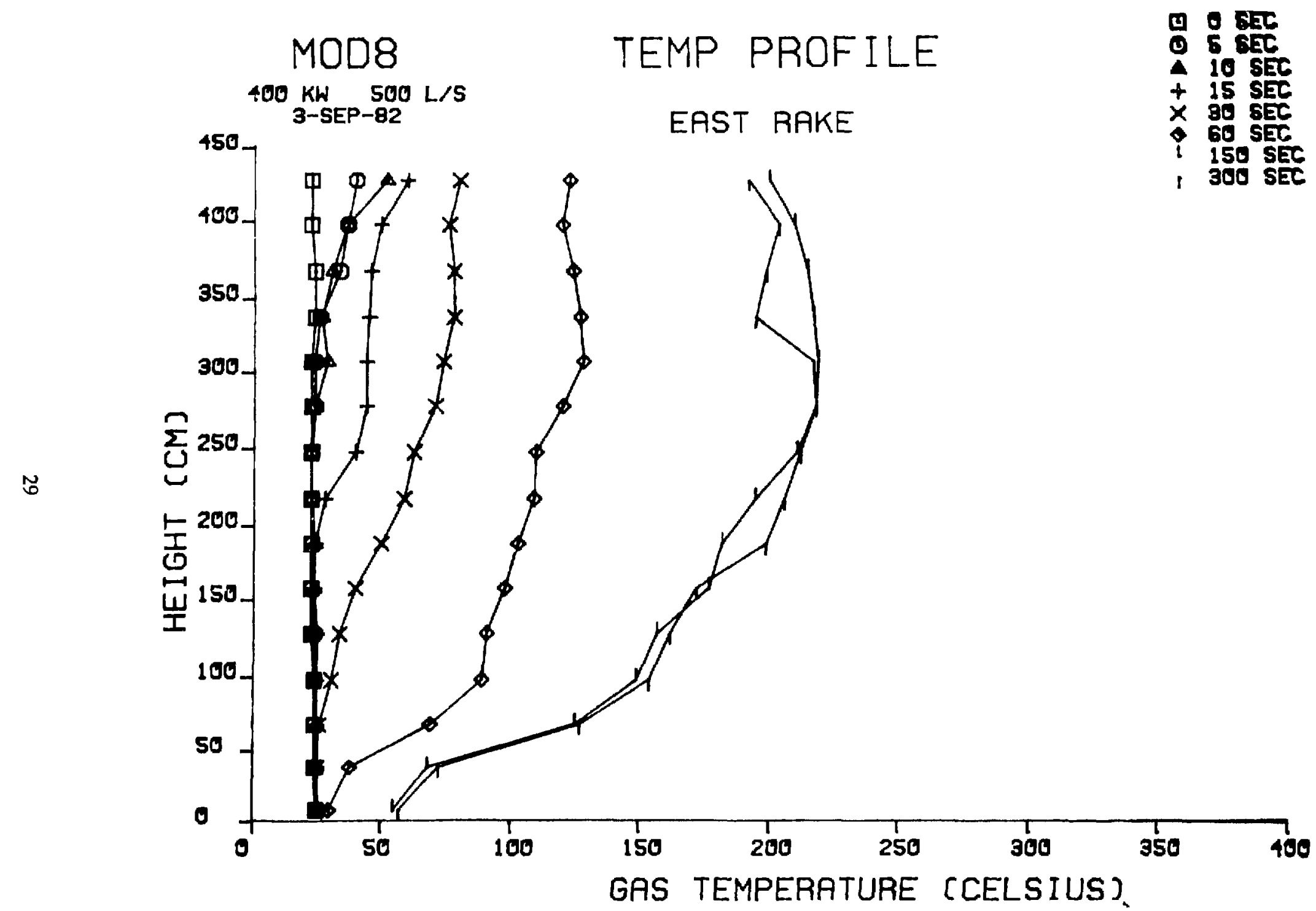

Figure 26. Mod 8 temperature profile (east rake). 


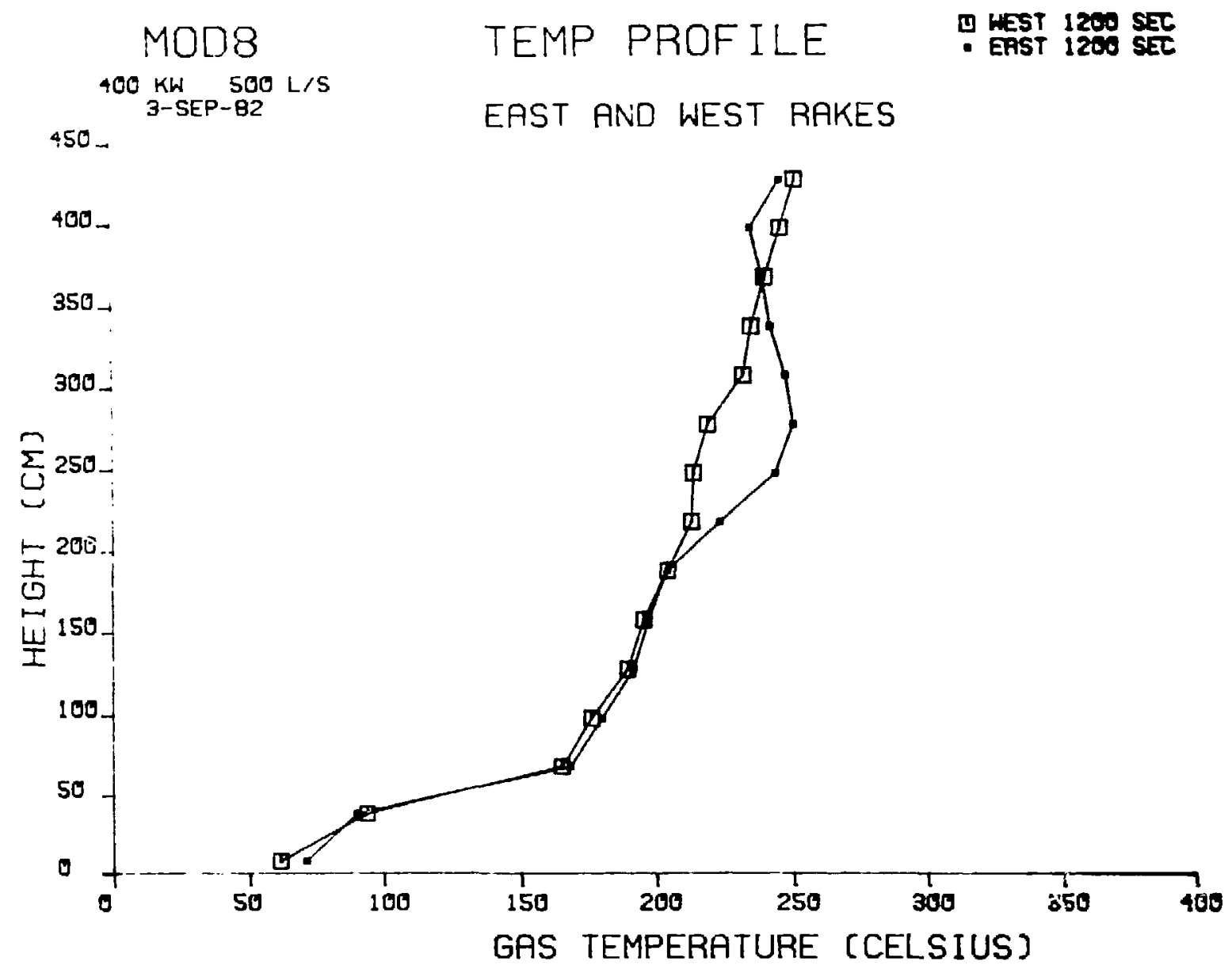

Figure 27. Mod 8 temperature profile with east and west rakes combined.

For model validation, it is necessary to ensure that measured parameters are as precise as possible. Therefore we took extreme care during data analysis to develop accurate information for other researchers. Perhaps the most important function is the equilibrium fire strength. Fire strength is defined initially by the direct measurement of fuel consumption and indirectly by measurement of $\mathrm{CO}$ and $\mathrm{CO}_{2}$ Froduction. Fire strength can also be defined independently by plume-height measurements of the fire. ${ }^{*}$ Table 8 compares fire-strength values calculated using these procedures. In general, we note there is a reasonable correlation between fire-strength values and adequately ventilated fires. In the cases where fires are poorly ventilated, wide discrepancies are apparent between fire strength calculations. Figure 29 is a graph of the empirical relationship between flame heights and fire strength developed by California Institute of Technology researchers and the flame- height data produced during our measurements. Note that we used this correlation to calculate fire strength from our measured flame-height data.

Appendix A contains the balancing equations we used to validate the accuracy of our data after all volumetric functions were converted to mass units. This procedure marks data inconsistencies, measurement faults, and equipment or calibration errors. We will now discuss the comparisons using these equations.

Figure 30(a) shows mass balance for Test 27B. Since the "mass net" hovers around zero, we are confident there were no leaks throughout the ventilation circuit and test cell. Figure 30(b) compares fire strength as computed by the product of fuel-flow rate and heat of combustion, and fire strength computed from $\mathrm{CO}$ and $\mathrm{CO}_{2}$ production. The fact that these two fire strengths do not match indicates inefficient burning. Since the discrepancy is not large, we can assume that the fire was 


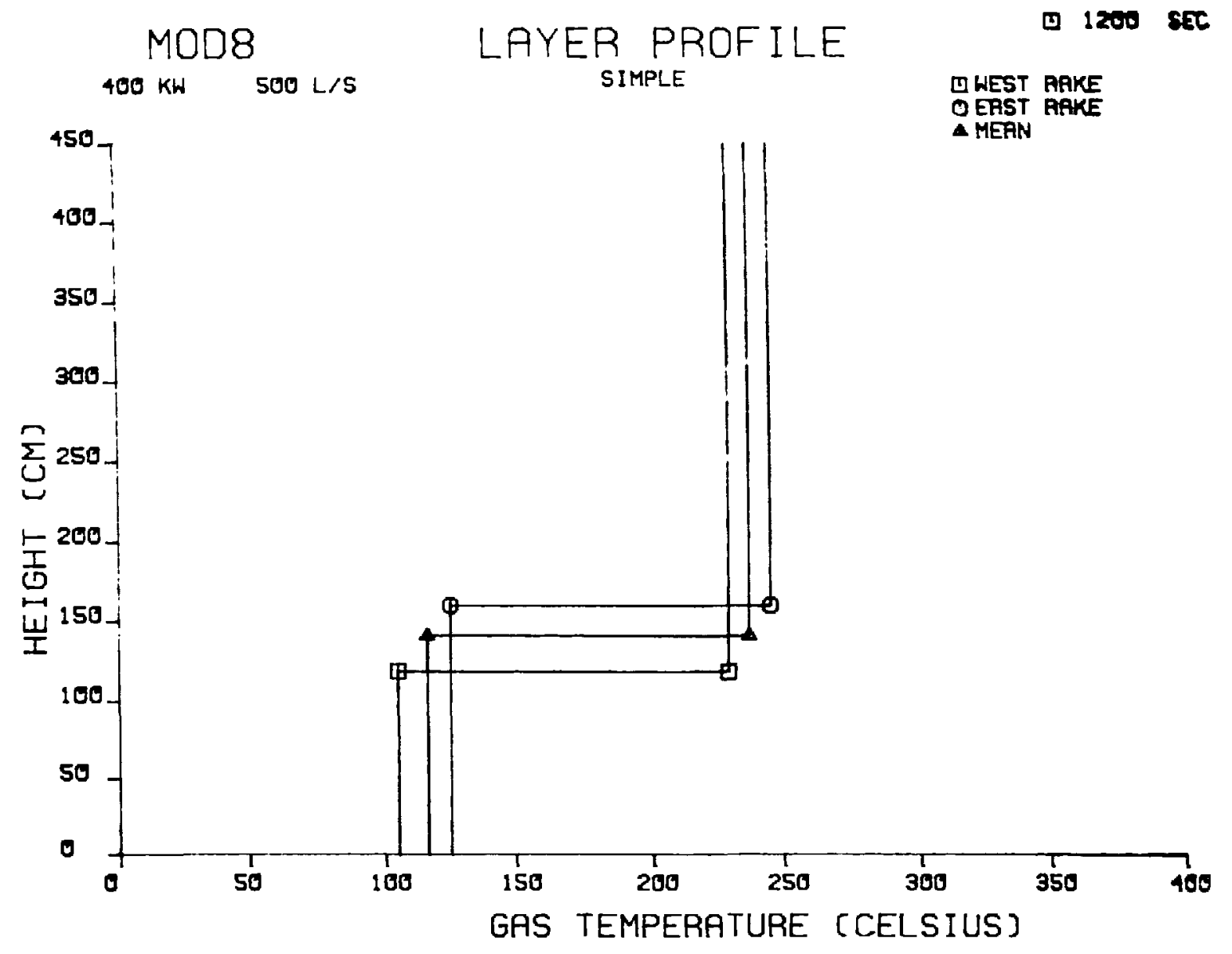

Figure 28. Mod 8 layer profile.

only slightly ventilation-controlled. Figure 30(c) accounts for gas energy into and out of the enclosure. Also, by subtracting the net energy to the gas from the fire strength determined by $\mathrm{CO}$ and $\mathrm{CO}_{2}$ production, we can calculate directly the total energy to enclosure surfaces which is indicated as $\theta$ wall in (c). Figure 30(d) shows the generation and removal of atomic species in the enclosure during the test. The reason we did not attain species balance was again due to inadequate ventilation of the fire.

Figure 31 contains the same balancing data for a fully ventilated fire. Here, Fig. 31(a) shows the only inconsistency of these data. Massbalance calculations indicate more gas leaving than entering the test cell. Apparentlv, the anemometers were not calibrated or the test cell leaked. Figures 31(b) through (d), however, show excellent balance, indicating fully ventilated conditions for the fire. The imbalance of the massflow of air is not important for these parameters since they depend only on conditions in the outlet duct.

Table 9 lists the results of the FY 82 test series. We found Tests $2,3,11,20,21$ and 22 insufficient for our modeling purposes and eliminated them. Data contained in this table are semiequilibrium values. These data will be used to preliminarily rate models and to establish criteria for FY 83 tests. 
Table 8. Comparison of fire strength caiculations.

\begin{tabular}{|c|c|c|c|c|c|c|c|}
\hline Tes & & Fuel type & $\begin{array}{c}\text { Air flow } \\
(1 / s)\end{array}$ & $\begin{array}{l}\text { Physical } \\
\text { fire strength } \\
\text { (kw) }\end{array}$ & $\begin{array}{c}\text { Measurement } \\
\text { procedure }\end{array}$ & $\begin{array}{l}\mathrm{CO}, \mathrm{CO}_{2} \\
\text { firc strength } \\
(\mathrm{kW})\end{array}$ & $\begin{array}{c}\text { Flame height } \\
\text { fire strength } \\
(\mathrm{kW})\end{array}$ \\
\hline MOD & 1 & Methane & 250 & 135 & By critical & 159 & 197 \\
\hline & 2 & Methane & 500 & 55 & orifices and & 90 & 74 \\
\hline & 3 & Methane & 100 & 60 & turbine flow- & 76 & 65 \\
\hline & 4 & Methane & 100 & 230 & meters & 222 & $280-500$ \\
\hline & 5 & Methane & 500 & 455 & & 592 & 450 \\
\hline & 6 & Methane & 100 & $\$ 60$ & & 214 & $=800$ \\
\hline & $6 A$ & Methane & 100 & 470 & & 275 & $=800$ \\
\hline & 7 & Methane & 250 & 135 & & 175 & 192 \\
\hline & 8 & Isooctane-Propanol & 500 & 400 & By flow rates & 420 & 310 \\
\hline & 9 & Isooctane-Propanol & 500 & 800 & and physical & 891 & $=500$ \\
\hline & $9 A$ & Isooctane-Propanol & 500 & 800 & calibration & 712 & $=500$ \\
\hline & 10 & Isooctane-Propanol & 100 & 100 & & 81 & 121 \\
\hline & 11 & Isooctane-Propanol & 500 & 100 & & 135 & 121 \\
\hline & $11 \mathrm{~A}$ & Isooctane-Propanol & 500 & 100 & & 120 & 121 \\
\hline & 12 & Isooctane-Propanol & 100 & 800 & & 234 & $=500$ \\
\hline & 13 & Isooctane-Propanol & 500 & 400 & & 437 & 342 \\
\hline & 14 & Isooctane-Propanol & 500 & 400 & & 389 & 310 \\
\hline & $14 A$ & Isooctane-Propanol & 500 & 400 & & 335 & 310 \\
\hline & 15 & Isooctane-Propanol & 500 & $\mathbf{8 0 0}$ & & +22 & $=380$ \\
\hline & 16 & Isooctane-Propanol & 100 & 800 & & 142 & $=390$ \\
\hline & 17 & Propanol & 500 & 600 & By weight loss & 127 & $=\mathbf{5 0 0}$ \\
\hline & 18 & Isooctane & 100 & $500-350$ & & 168 & 342 \\
\hline & 19 & Isooctane & 500 & $1100-500$ & & 567 & $3+2$ \\
\hline & 20 & Polystyrene & 500 & $500-400$ & & 52 & 60 \\
\hline & 23 & Isooctane & 100 & 400 & By flow rates & 188 & 195 \\
\hline & 24 & Isooctane & 100 & 200 & $\begin{array}{l}\text { and physical } \\
\text { calibration }\end{array}$ & 155 & 195 \\
\hline & 25 & Propanol & 100 & 200 & & 198 & 250 \\
\hline & 26 & Propanol & 100 & 400 & & 280 & $=300$ \\
\hline & 27 & Propanol & 250 & 400 & & 339 & $\simeq 400$ \\
\hline & $27 \mathrm{~A}$ & Propanol & 250 & 400 & & 323 & $=400$ \\
\hline & 28 & Propanol & 250 & 400 & & 366 & 312 \\
\hline
\end{tabular}




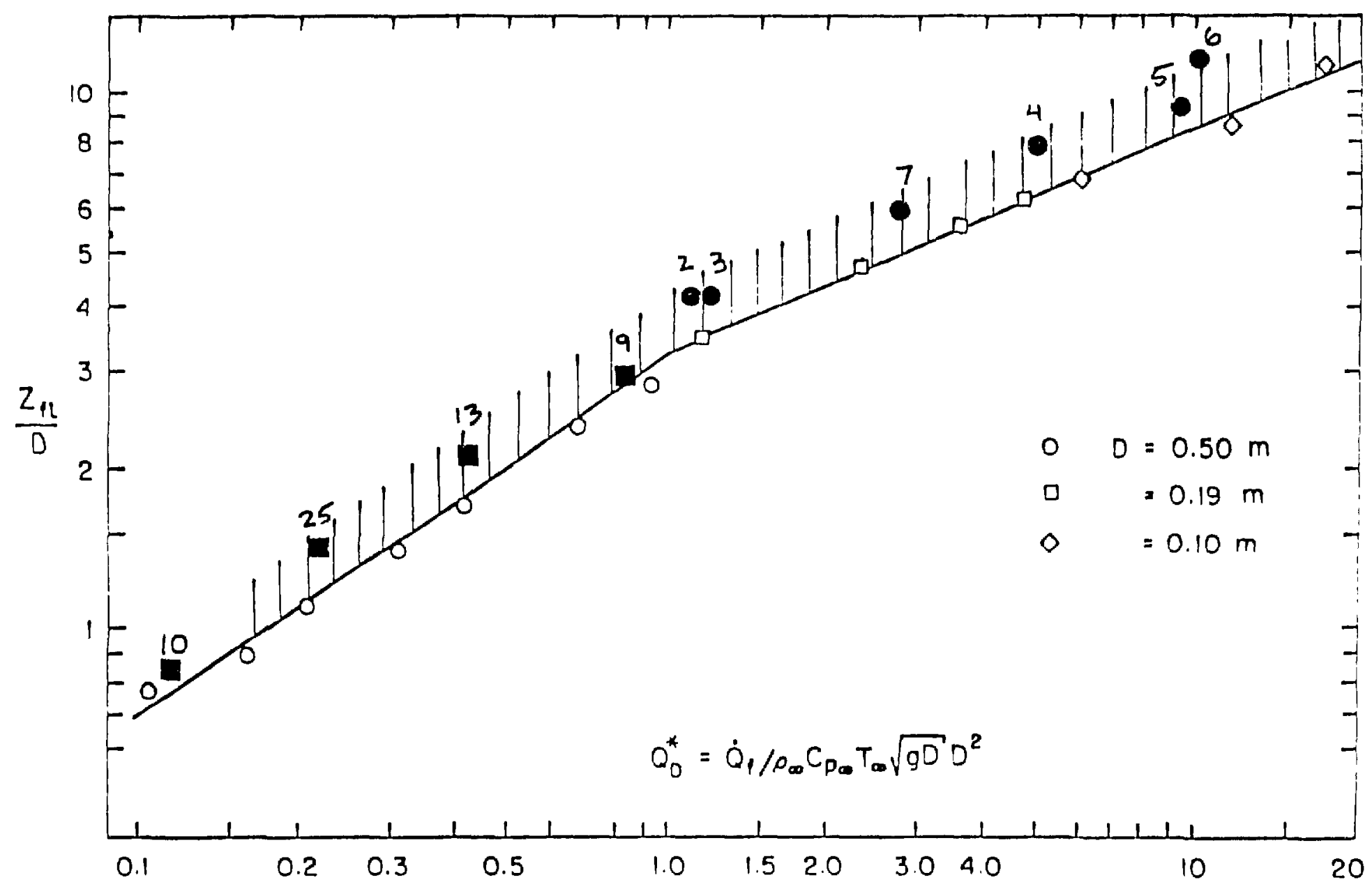

Figure 29. Comparison of FY 82 LLNL model test data with Zukoski's calculations. 


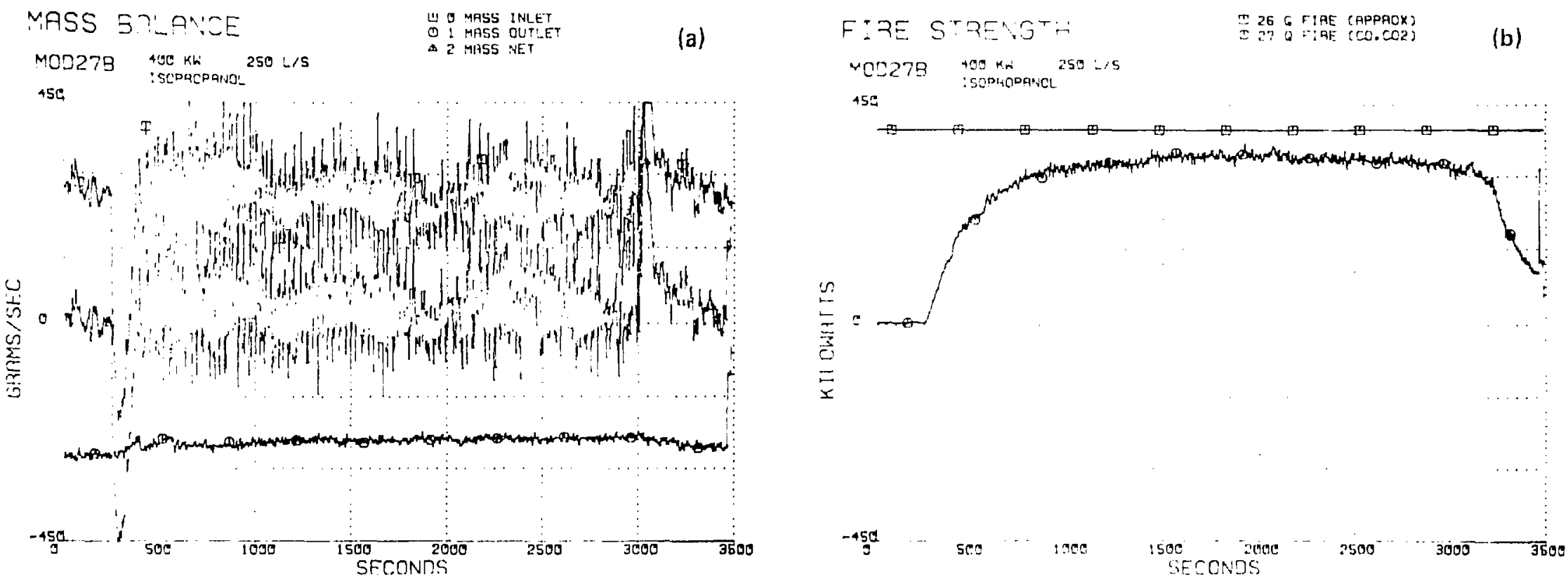

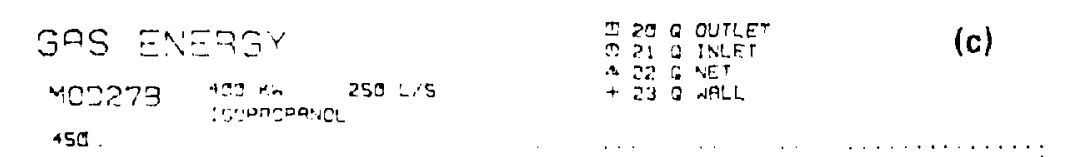
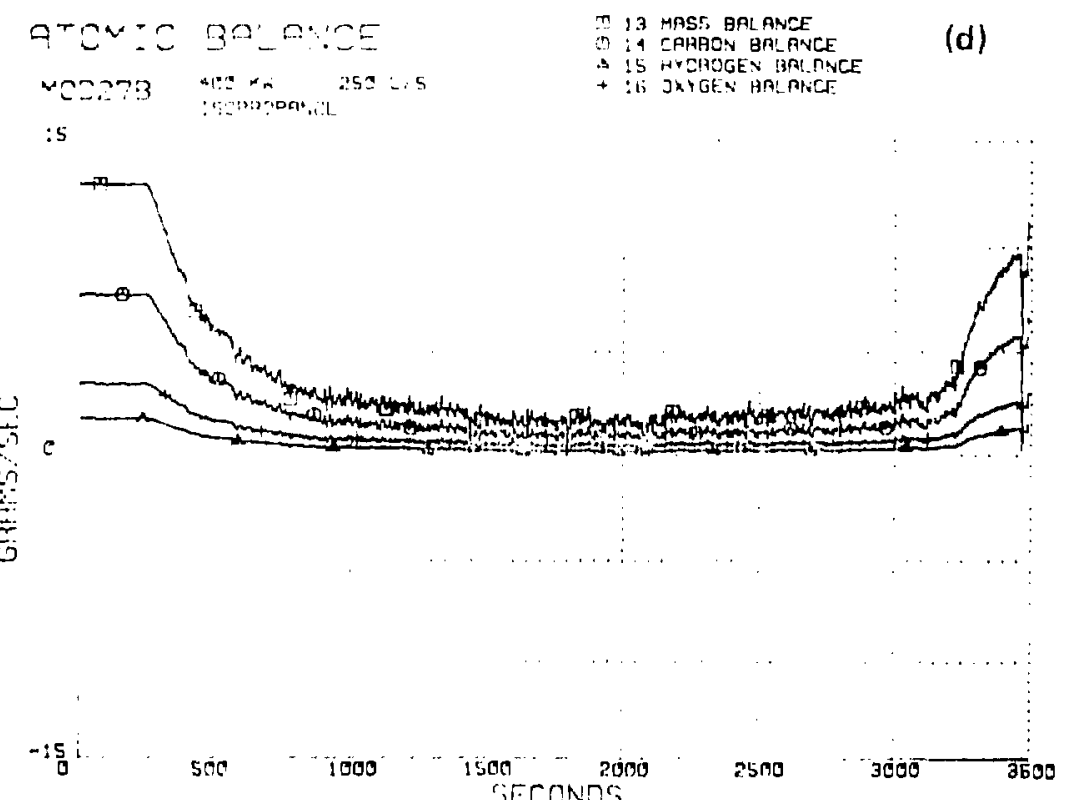

Figure 30. Four views of Mod 27B profile (a) mass balance, (b) fire strength, (c) gas energy, and (d) atomic species balance. 


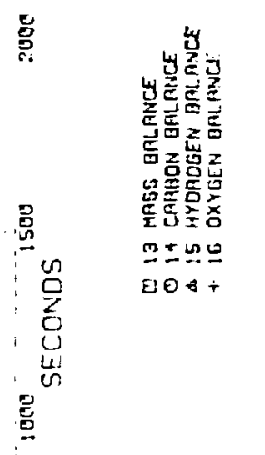

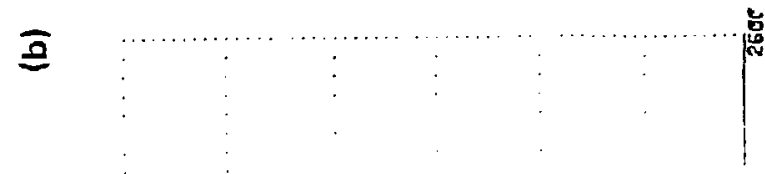

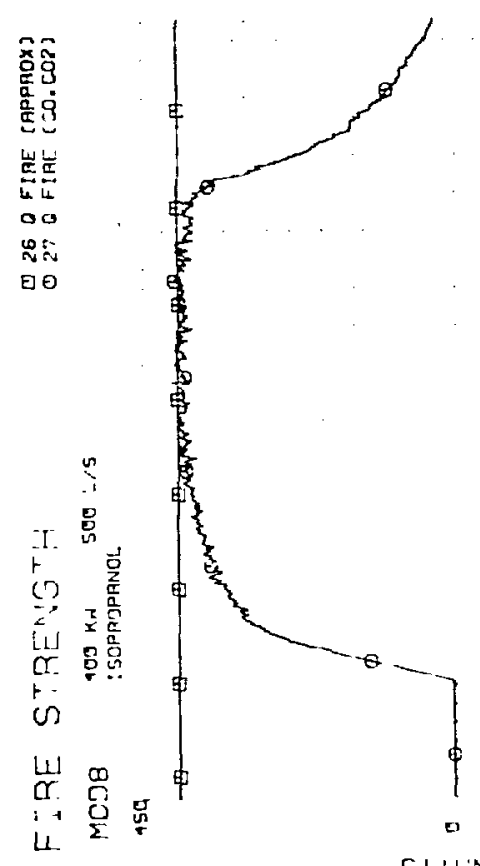

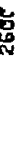

SIJ JNAO II H

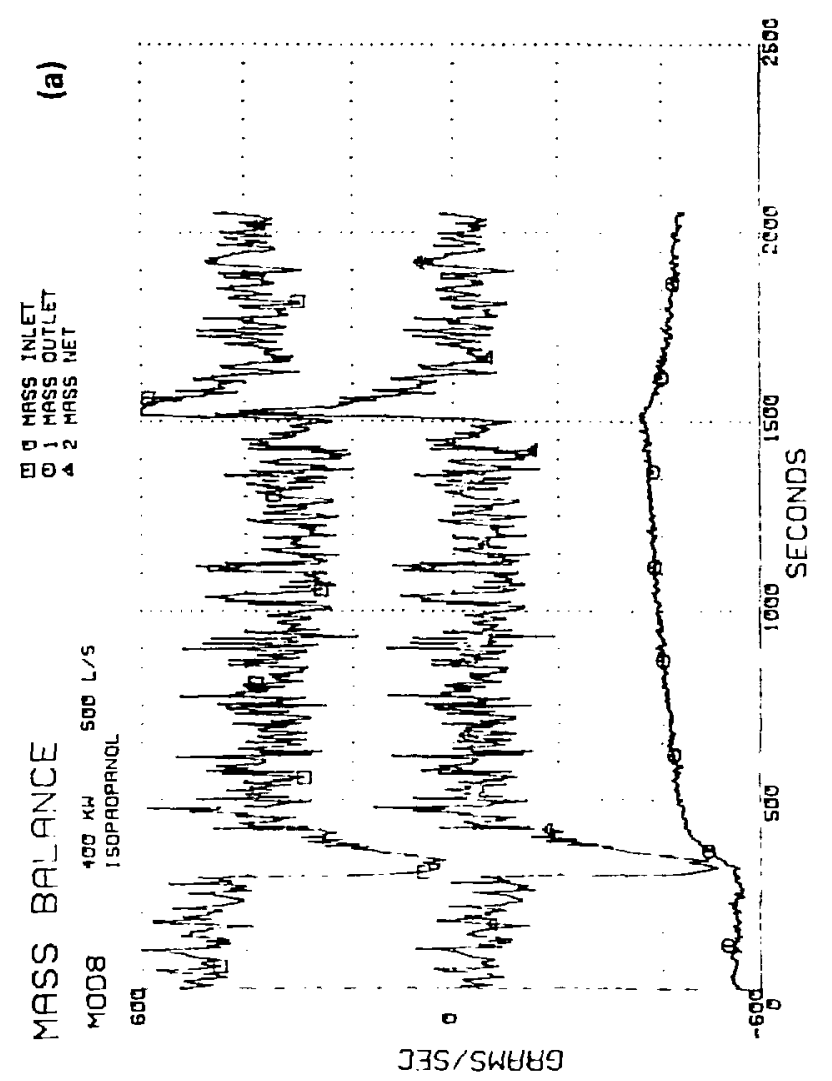

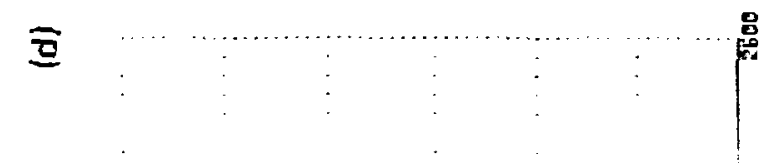

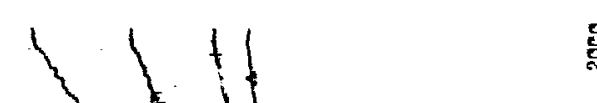

g

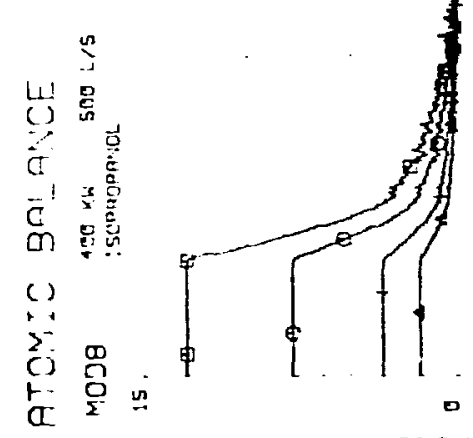

J45/Shitro

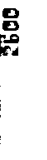

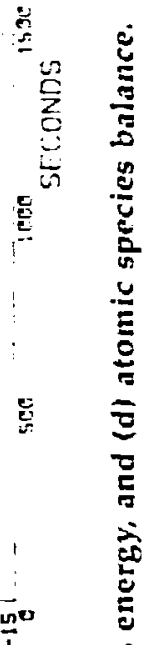

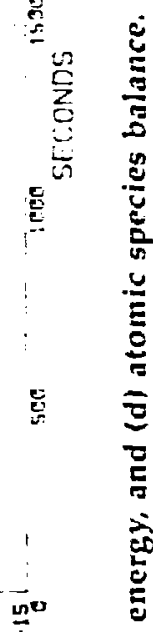

E

E

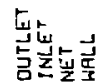

3000
Nㅠ
ำt

בent

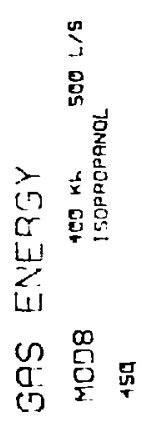


Table 9. FY 82 results for fire modeling.

\begin{tabular}{|c|c|c|c|c|c|c|c|c|c|c|c|c|c|}
\hline $\begin{array}{l}\text { MOD } \\
\text { No. }\end{array}$ & $\begin{array}{c}Q \\
(k W)\end{array}$ & $\begin{array}{l}\text { Fuel } \\
\text { flow } \\
(1 / 5)\end{array}$ & $\begin{array}{c}\text { Fuel } \\
\text { formula }\end{array}$ & $\begin{array}{l}\text { Inlet } \\
\text { reversal } \\
\text { boftom } \\
\text { value }\end{array}$ & $\begin{array}{c}\text { Observed } \\
\text { flame } \\
\text { height } \\
(\mathrm{m})\end{array}$ & $\begin{array}{l}\text { Steckler } \\
\text { layer } \\
\text { height } \\
\text { (ni) }\end{array}$ & $\begin{array}{l}\text { Exit } \\
\text { and air } \\
\text { temp. } \\
\text { ("C) }\end{array}$ & $\begin{array}{l}\text { Top } \\
\text { twall } \\
\text { temp. } \\
\text { ('C) }\end{array}$ & $\begin{array}{c}\because \text { Heat } \\
\text { lotis } \\
\text { to } \\
\text { walls }\end{array}$ & $\begin{array}{c}\mathrm{O}_{2} \\
\text { consumed } \\
(n, s)\end{array}$ & $\begin{array}{l}\mathrm{CO} \\
(\mathrm{H} / \mathrm{s})\end{array}$ & $\begin{array}{l}\mathrm{CO} \\
(\mathrm{g} / \mathrm{s})\end{array}$ & $\begin{array}{l}\mathrm{CH} \\
\lg / \mathrm{s} \mid\end{array}$ \\
\hline 10 & 100 & 100 & $\mathrm{C}_{3} \mathrm{H}_{\mathrm{B}} \mathrm{O}$ & $180^{\prime \prime}$ & 0.8 & 1.27 & 100 & 80 & 87 & 2.4 & 5.4 & - & - \\
\hline 4 & 230 & 100 & $\mathrm{CH}_{4}$ & 200 & $2.2^{k}$ & $1.36^{\circ}$ & 170 & 150 & 45 & 1.3 .8 & 10.7 & 1.7 & 0.3 \\
\hline 24 & 200 & 110 & $\mathrm{C}_{8} \mathrm{H}_{1 \mathrm{IS}}$ & -80 & $1.1^{\prime \prime}$ & 1.115 & 150 & $1+5^{\circ}$ & 8.3 & 10.3 & 10.5 & 0.3 & 0.07 \\
\hline 25 & 200 & 90 & $\mathrm{C}_{3} \mathrm{H}_{k} \mathrm{O}$ & 260 & 1.3 & 1.24 & $|6|$ & $160^{\prime \prime}$ & 80 & $1+.2$ & 12.5 & 1.7 & 0.03 \\
\hline 6 & 400 & 100 & $\mathrm{CH}_{4}$ & -440 & $3.0^{11}$ & 1.34 & 200 & 180 & $1000^{\prime}$ & 12.4 & 4.4 & 1.5 & 0.58 \\
\hline $6 A$ & 400 & 100 & $\mathrm{CH}_{4}$ & -430 & $3.0^{11}$ & $1.39^{\circ}$ & 190 & 170 & $100^{\prime}$ & 1.3 .7 & 10.8 & 2.2 & 0.61 \\
\hline 23 & 400 & 130 & $\mathrm{C}_{8} \mathrm{H}_{1 \mathrm{~B}}$ & $-300^{5}$ & 1.1 & 1.12 & 180 & 150 & 8,3 & 15.4 & 1.3 .1 & - & 0.66 \\
\hline 26 & 400 & 100 & $\mathrm{C}_{3} \mathrm{H}_{\mathrm{H}} \mathrm{O}$ & -300 & 1.6 & 1.11 & 180 & $180^{\circ}$ & - & 17.8 & 14.7 & 5.3 & 0.37 \\
\hline 5 & 455 & 500 & $\mathrm{CH}_{4}$ & $\cdots 150$ & $2.5^{k}$ & $1.44^{\prime \prime}$ & 280 & 210 & 8.3 & 36,0 & 32.6 & - & 0.0 .4 \\
\hline 8 & 400 & 500 & $\mathrm{C}_{3} \mathrm{H}_{\mathrm{B}} \mathrm{O}$ & +20 & 1.6 & 1.2. & 200 & 160 & 8.5 & 24,0 & 30.3 & - & - \\
\hline 13 & 400 & 500 & $\mathrm{C}_{3} \mathrm{H}_{\mathrm{g}} \mathrm{O}$ & -60 & 1.6 & 1.12 & 2.30 & 180 & 74 & 20.9 & 31.5 & - & - \\
\hline 14 & 400 & 500 & $\mathrm{C}_{H} \mathrm{H}_{\mathrm{HH}}$ & +40 & 1.5 & 1.01 & 200 & 150 & 74 & $12.4^{\circ}$ & $27.1^{\mathrm{H}}$ & $-k$ & 0.0 .4 \\
\hline $14 \mathrm{~A}$ & 400 & 500 & $\mathrm{C}_{\mathrm{B}} \mathrm{H}_{\mathrm{IH}}$ & -60 & 1.5 & 7.40 & 200 & 150 & 68 & 13,04 & $23.4^{H}$ & $-k$ & 0.04 \\
\hline 9 & 800 & 500 & $C_{3} H_{8} O$ & -170 & 2.3 & 1.10 & 280 & 225 & $8 B$ & 55.2 & 50.5 & 13.2 & 2.0 \\
\hline $9 A$ & 800 & 500 & $\mathrm{C}_{\mathbf{3}} \mathrm{H}_{\mathrm{R}} \mathrm{O}$ & -200 & 2.3 & 1.47 & 280 & 220 & 87 & $A+. M$ & 46.9 & 4.3 & 1.9 \\
\hline 15 & 800 & 500 & $\mathrm{C}_{\mathrm{H}} \mathrm{H}_{18}$ & -360 & $1.7+$ & 1.11 & 255 & 200 & 82 & $17.0^{4}$ & $24.4^{3}$ & $-k$ & 1.7 \\
\hline 1 & 135 & 250 & $\mathrm{CH}_{4}$ & -100 & 1.6 & $1.45^{\prime}$ & 130 & 90 & 4.1 & H. 7 & 8.7 & - & - \\
\hline , & 135 & 250 & $\mathrm{CH}_{4}$ & -100 & 1.6 & 1.24 & 140 & 105 & $\mathrm{H2}$ & $9.3^{11}$ & 9.6 & - & - \\
\hline 27 & 400 & 250 & $\mathrm{C}_{7} \mathrm{H}_{\mathrm{H}} \mathrm{O}$ & -180 & 1.71 & 1.10 & 220 & $220^{\prime \prime}$ & 9.5 & 23.6 & 21.4 & 2.4 & 0.02 \\
\hline $27 \mathrm{~A}$ & 400 & 250 & $\mathrm{C}_{3} \mathrm{H}_{\mathrm{B}} \mathrm{O}$ & $-400^{s}$ & 1.7 & 1.02 & 210 & $2000^{\circ}$ & 9 & 20.7 & 23.3 & - & 0.14 \\
\hline $27 \mathrm{~B}$ & 400 & 250 & $\mathrm{C}_{3} \mathrm{H}_{\mathrm{H}} \mathrm{O}$ & -160 & 1.6 & $1.0 \mathrm{~s}$ & 205 & $185^{\circ}$ & 84 & 2.4 .9 & 26.4 & .. & 0.11 \\
\hline 17 & 600 & 500 & $\mathrm{C}_{3} \mathrm{H}_{\mathrm{H}} \mathrm{O}$ & 180 & 2.0 & $1.0 \mathrm{H}$ & 250 & 145 & 1.3 & $5,6^{H}$ & n. $8^{k}$ & $2.2^{\mu}$ & - \\
\hline 18 & 400 & 100 & $\mathrm{C}_{3} \mathrm{H}_{\mathrm{H}} \mathrm{O}$ & -460 & 1.6 & 1.12 & $I(6)$ & 150 & 83 & $9 . .3 n$ & $7.6^{\prime \prime}$ & $4.3^{3 k}$ & - \\
\hline I9 & 1100 & 500 & $\mathrm{C}_{H} \mathrm{H}_{1 \mathrm{H}}$ & $\ldots \mathbf{3 3 0}$ & 2.11 & C.139 & 255 & 200 & - & 36.3 & 29.0 & 9.4 & - \\
\hline 12 & 800 & 100 & $C_{1} H_{H} O$ & 600 & 2.5 & - & - & - & - & - & . & $\ldots$ & - \\
\hline 16 & $\mathrm{HOO}$ & 100 & $\mathrm{C}_{H} \mathrm{H}_{\text {IH }}$ & 700 & 1.7 & $\ldots$ & - & - & . &. & $-" 1$ & .." & - \\
\hline
\end{tabular}

" Hesides a gradual blow reveryal, here was an extreme spilke.

l. Note llat the flame was in the hot hyer.

- Test was terminated before it reached quasi-e(jullitrium.

"This fire did not fill the pan.

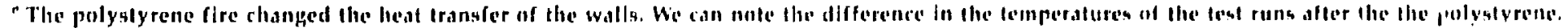

'This fire should have been a $200 \mathrm{~kW}$ fire hat il was a $100 \mathrm{~kW}$ fire for the firal two minntou.

"A leak in the sample diluled all of these messurements.

"MOD 7 ran 800 seconds longer than MOD 4. 


\section{Gire Chemistry: Thermal Degradation of Cable and Wire Insulations}

\section{Introduction}

Last year's st:tdy on thermal degradation of PVC and rubber cable insulations showed that the decomposition of the insulations is influenced by the additives that are incorporated into the plastic formulations. Some of the additives, such as alkyl phthalates or adipates, enhance the degradation rate of the pure polymer and/or thernselves thermally degrade into flammable species that feed the flames. We also learned that the formation rate of corrosive products, mainly $\mathrm{HCl}$, is enhanced by higher rates of heating. How'ever. higher heating rates do not increase the total $\mathrm{HCl}$ production. The amuunt of $\mathrm{HCl}$ released :::to the environment is governed by acid acceptors (e.g., $\mathrm{ZnO}, \mathrm{MgO}, \mathrm{Sb}_{2} \mathrm{O}_{3}$ and $\mathrm{CaCO}_{3}$ ) incorporated into the plastic formulations. Flame retardants like $\mathrm{Sb}_{2} \mathrm{O}_{3}$, alumina trihydrate, and triaryl phosphates increase the extent of charring and decrease the degradation rate, especially in the dehydrochlorination region. ${ }^{3}$

This year we subjected the PVC and previously studied rubber insulations to heating rates of 30 and $160^{\circ} \mathrm{C} / \mathrm{min}$ to see what effect these may have on the degradation rate of the plastic formulations, and we also extended our detailed studies to other wire and cable insulations, including additional rubber insulations, nolyethylene, polyprcpylene, nylon, polyurethane and mylar. Samples were subjected to differential scanning calorimetric analysis (DSCA) and to thermogravimetric analysis (TCA) at several heating rates to determine the effect of heating on the temperature responsible for the onset of initial weight loss, the generation rate of corrosive products, and the amount of residual ash. In addition, we subjected the gaseouc and liquid pyrolyzates to gaschromatographic and mass-spectrometric analysis.

\section{Experimental Procedure}

In the first set of experiments, we heated virgin polymers and various cable and wire insulations in air in our thermogravimetric analyzer at rates of $10,20,40,80$ and $160^{\circ} \mathrm{C} / \mathrm{min}$ from ambiert temperature to $900^{\circ} \mathrm{C}$. As reported previously, we monitored the samples' weights and the generation of acidic components as a function of tem- perature. As before, the acidic components and other thermal degradation products were directed to a container filled with $200 \mathrm{ml}$ of distilled water buffered to a $\mathrm{F}$ :H of $6.8-7.0$. The aqueous solution was gently stirred with a magnetic stirrer to i.chieve uniform mixing and the change in $\mathrm{pH}$ "as measured with a pencil-size $\mathrm{pH}$ reference electrode and recorded on a multichannel recorder

DSC analysis was performed on a Duroni900 differential scanning calorimeter using a standard cell. Our samples weighed between 5 and $10 \mathrm{mg}$ and all were heated in air at $20 \mathrm{C} \mathrm{min}$.

In the second set of experiments. we sought to identify the major degradation products formed during the initial and most active phases of purolysis. Such knowledge is particularly useful when choosing or designing early-waming smoke alarm systems, or identifying formulations that contain highly flammable adtitues or contaln additives which in themselves are not llammable but form highly flammable species at high temperatures that contribute to flamespread.

Degradation products were either generated in the thermogravimetric analyzer or in a tube $\mathrm{py}$ rolyzer. fill samples were pyrolyzed in air and the degradation products were collected in a liquidnitrogen-cooled trap. We chose the pyrolysis temperature used in the tube pyrolyzer on the basis of our TGA results; the pyrolysis temperature was set at temperatures responsible for the initial as well as the main degradation phase. After collection, a plastic bag was wrapped tightly over the top of the liquid-nitrogen-cooled trap and then the trap was brought to room temperature. This technique separated the gaseous components from the liquid pyrolyzates and allowed for simultaneous gas chromatographic analysis of both the gaseous and liquid mixtures. Aliquots of $4.0 \mathrm{cc}$ of the gaseous, mixtures were injected into a 10 it $\times 1 / 4$ in. glass column packed with $0.19^{\circ} \mathrm{o}$ picric acid on $80 / 190$ Carbopack $C$. The column was held at $40^{\circ} \mathrm{C}$ for 2 minutes, then programmed to $55^{\circ} \mathrm{C}$ at $15^{\circ} \mathrm{C} / \mathrm{min}$ and held at this temperature for 10 minutes. To separate out the heavier gaseous components, the column " as next raised to $70^{\circ} \mathrm{C}$ at a rate of $15^{\circ} \mathrm{C} / \mathrm{min}$ and allowed to remain there until the end of each run. We used nitrogen as our carrier gas at a flow rate of $30 \mathrm{ml} / \mathrm{min}$ and the injectior. port and a flame ionization detector were both set at $100^{\circ} \mathrm{C}$. T' 1 compounds comprising the gaseous mixture were identified by comparing the 
retention times with the retention times of standard compounds.

The glass trap was next washed with methylene chloride and the sol cent containing the liquid pyrolyzate was concentrated down to $6.5 \mathrm{ml}$. A. 3 - $\mu$ iiter aliquot was then injected into a $25-\mathrm{m}$ Carbowax-20M fused-silica capillary column, a 25-m SE-30 fused-silica capillary column, and a SE-5 4 fused-silica capillary column. The use of the polar and non-polar general purpose columns, as well as the SE-54, which is designed for separation of the polycyclic components, gave us a better idea of the pyrolyzate mixture. As mentioned in previous reports, the column oven was programmed to heat from $70^{\circ} \mathrm{C}$ to $220^{\circ} \mathrm{C}$ at a rate of $10^{\circ} \mathrm{C} / \mathrm{min}$. Helium flow rate was maintained at $6 \mathrm{ml} / \mathrm{min}$, and the injec ${ }^{2}$ in port, mass-spec transfer line, and jet separator were set at $250^{\circ} \mathrm{C}$. The components that comprised the separated peaks were identified with the help of our computerized spectral library system.

\section{Experimental Results}

\section{PVC}

The PVC insulations used in our experimnts were designed for high-power cables, multistrand general-purpose cables, and general appliance cables.

Detailed description of the thermograms of the various PVC cables appeared in last year's report. "This year's data on the effect of higher heating rates on the degradation mode of the various Neoprene insulations we tested is summarized in Table 10 . We see that higher heating rates do not drastically alter the temperature responsible for the onset of weight loss in either the main degradation phase or the subsequent phase or phases of degradation. The small variations in temperature leading to the onset of weight loss in the second and third phases seem to be within experimental error and cannot be attributed primarily to heating rates. As expected, higher heating rates increase degradation rates with the most pronounced effect being in the main phase of pyrolysis that is responsible for the production of $\mathrm{HCl}$. Although faster heating rates tend to meld the different degradation phases, and it appears that the length of the main phase increases with the faster heating rates, the total amount of $\mathrm{HCl}$ formed during pyrolysis remains constant at all heating rates (Fig. 32).
Weight-loss rates varied among the different PC formulations, and, in general, seemed to be lower than those of virgin PVC. The total weight loss in each region was also governed by the additiv es present and varied from one formulation to another. The different additives also influenced the amount of char formed at the end of pyrolysis. For example, at a heating rate of $40^{\circ} \mathrm{C} / \mathrm{min}$, PVC-3 left a char residue of $11 \%$, PVC-95 left a $23 \%$ char, and PVC-104 left a char residue of $5 \%$. In contrast, virgin polymer did not leave any residue. The principal char-forming additives used in PVC formulations associated with fire retardance are $\mathrm{Sb}_{2} \mathrm{O}_{3}$, alumina trihydrate, calcinated clay, and phosphate esters. Depending upon the manufacturer, commonly used PVC formulations contain anywhere between one and three of the above mentioned additives in a single formulation."

Last year's gas-chromatographic, massspectrometric analyses of the liquid pyrolyzates showed that the largest variety of products are formed in the dehydrochlorination region, or the main decomposition phase, and the components collected in subsequent phases consist mainiy of polynuclear hydrocarbons. Since these results did not include analysis of the gaseous pyrolyzates. and since we felt there may have been some loss of the liquid pyrolyzate through condensation on the walls of the TGA furnace tube, this year's work included analyses of the gaseous products as well as repeat analyses of the liquid products generated in the tube pyrolyzer. The tube pyrolyzer allowed us to use larger samples as well as diminish some of the liquid-pyrolyzate loss through condensation prior to liquid nitrogen trapping.

Gas-chromatographic analysis results of the gaseous products of virgin PVC and a representative PVC insulation are shown in Figs. 33(a) and (b). The chromatograms show that both virgin PVC and the PVC-104 give off methane, ethylene, acetylene, ethane, propane, propylene, propyne, isobutane, $n$-butane and 1-butane, isobutylene and ethylacetylene. In addition, PVC-104 shows 1,3-butadene, pentane, 4-methyl-pentene-1, and cis-hexene-2. All except 1,3-butadiene elute between 16 and 45 minutes after injection (not shown in these chromatograms) and appear in PVC-3 and PVC-78. We attribute these formations to the degradation of some of the additives used in the formulations. Results of the analysis of the liquid pyrolyzate are summarized in Appendix B (Figs. B1-B4). The chromatograms show that although the dehydrochlorination region leads 
Table 10. The effec! of heating rate on the thermal degradation of PVC.

\begin{tabular}{|c|c|c|c|c|c|c|c|c|c|}
\hline \multirow[b]{2}{*}{ Sample } & \multirow[b]{2}{*}{$\begin{array}{l}\text { Heating } \\
\text { rate } \\
\left({ }^{\circ} \mathrm{C} / \mathrm{min}\right)\end{array}$} & \multicolumn{2}{|c|}{ Main phase ${ }^{2}-1$ st phase } & \multicolumn{2}{|c|}{ 2nd phase } & \multicolumn{2}{|c|}{ 3rd phase } & \multirow{2}{*}{$\begin{array}{l}\text { Wt loss } \\
\text { in main } \\
\text { phase } \\
(\%)\end{array}$} & \multirow{2}{*}{$\begin{array}{c}\text { Char at end } \\
\text { of } \\
\text { pyrolysis } \\
(\%)\end{array}$} \\
\hline & & $\begin{array}{c}\text { Onset of } \\
\text { wt loss } \\
\left({ }^{\circ} \mathrm{C}\right)\end{array}$ & $\begin{array}{c}\text { Degradation } \\
\text { rate } \\
(\% / \text { min })\end{array}$ & $\begin{array}{c}\text { Onsel of } \\
\text { wt loss } \\
\left({ }^{\cup} \mathrm{C}\right)\end{array}$ & $\begin{array}{c}\text { Degradation } \\
\text { rate } \\
(\% / m i n)\end{array}$ & $\begin{array}{c}\text { Onset of } \\
\text { wt loss } \\
\left({ }^{\circ} \mathrm{C}\right)\end{array}$ & $\begin{array}{c}\text { Degradation } \\
\text { rate } \\
(\% / \mathrm{min})\end{array}$ & & \\
\hline \multirow[t]{4}{*}{ PVC-3 } & 10 & 290 & 9.0 & 432 & 1.7 & 515 & 21.2 & 41.5 & $16^{4}$ \\
\hline & 20 & 280 & 16.0 & 425 & 3.5 & 510 & 22.0 & 46 & 15 \\
\hline & 40 & 260 & 37.0 & 390 & 6.0 & 480 & 23.0 & 51 & 11 \\
\hline & 80 & 290 & 80.0 & 420 & 20.0 & 430 & 26.0 & 56 & 8 \\
\hline \multirow[t]{5}{*}{ PVC-104 } & 10 & 270 & 9.0 & 441 & 6.5 & 530 & 4.0 & 9 & 14 \\
\hline & 20 & 255 & 11.0 & 410 & 12.5 & 510 & 6.0 & 9 & 14 \\
\hline & 40 & 270 & 28.0 & 400 & 4.0 & 515 & 21.0 & 18 & 5 \\
\hline & 80 & 270 & 40.0 & 380 & 35.0 & 500 & 25.0 & 20.5 & 5 \\
\hline & 160 & 280 & $25 / 12 \mathrm{~s}^{\mathrm{b}}$ & 365 & $33 / 30 \mathrm{~s}^{\prime \prime}$ & 510 & 30.0 & 25.5 & 5 \\
\hline \multirow[t]{4}{*}{ PVC-95 } & 10 & 262 & 12 & 402 & 2.5 & & & 31 & 23 \\
\hline & 20 & 270 & 22 & 405 & 3.0 & & & 30 & 23 \\
\hline & 80 & 280 & 80 & 420 & 12.0 & & & 51 & 10 \\
\hline & 160 & 260 & $51 / 18 \mathrm{~s}^{\mathrm{b}}$ & 410 & 18.0 & & & 53 & 13 \\
\hline \multirow[t]{5}{*}{ Virgin PVC } & 10 & 257 & 18 & 403 & 3.0 & & & 29 & $b^{3}$ \\
\hline & 20 & 265 & 30 & 411 & 10.0 & & & 41 & 0 \\
\hline & 40 & 260 & 56 & 405 & 14.5 & & & 47 & 0 \\
\hline & 80 & 285 & 70 & 420 & 11.0 & & & 52 & $n$ \\
\hline & 160 & 270 & $60 / 30 s^{b}$ & 380 & 45.0 & & & 60 & 0 \\
\hline
\end{tabular}

ApH change in main phase that occurred in PVC-3 and virgin PVC at 10 and $20{ }^{\circ} \mathrm{C} / \mathrm{min}$ was 7.10 and 4.42 and 7.17 and 3.7 ', respectively.

b Degradation rate occurred in less than 1 minute (example: $25 \%$ in 12 seconds). 


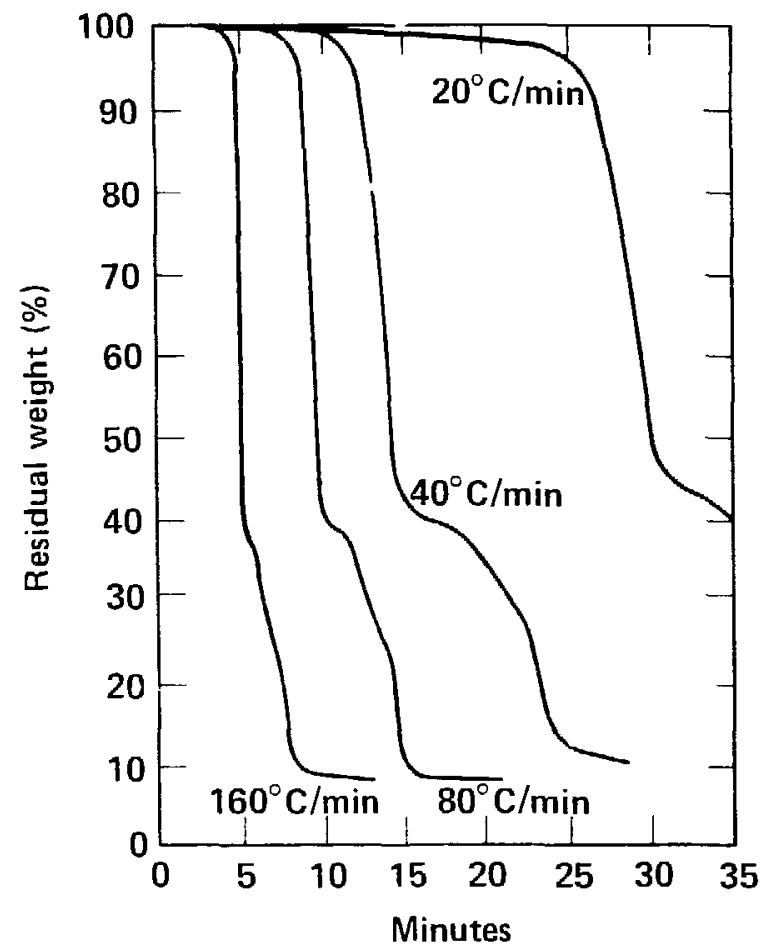

Figure 32. Effect of heating rate on thermal degradation of PVC.

mainly to the production of $\mathrm{HCl}$, other compounds, pr: dominantly of an aromatic nature, are also formed. Some of the compounds are degradation products of plasticizers, e.g., phthalic anhydride, from dioctylphthalate in PVC-3 and PVE78 , and lauric acid from dibutylene dilaurate and stearic acid from calcium stearaie present in PVC-104.

\section{Rubber Insulations}

We used rubber insulations designed for high-power, high-current cables, welding cables, single-conductor high-voltage cables, and multiconducior power cables. The insulations consisted of Neoprene, or polychloroprene, chlorinated and sulfonated polyethylene, and other synthetic rubbers. The insulations designated as Neoprene-007, Neoprene-84, Neoprene-435 and Rubber-134 were studied extensively last year. ${ }^{3}$ This year, we extended our detailed studies to five other rubber insulations and we performed additional thermogravimetric analyses and gaschromatographic analyses on the gaseous pyrolyzates of the previously studied formulations.

The effects of heating rates as high as $80^{\circ} \mathrm{C} / \mathrm{min}$ and $160^{\circ} \mathrm{C} / \mathrm{min}$ on the degradation of
Neoprene-007, -84, -435, virgin polychloroprene, and rubbers are shown in Table 11. As we previously described, the higher heating rates do not lower the temperature responsible for initial degradation of the various insulations. Higher heating rates increase the degradation rates of all the insulations and therefore lead to faster production of $\mathrm{HCl}$. Of the insulations studied, Neoprene- $435 \mathrm{de}$ grades the fastest and Neoprene- 84 degrades the slowest and leaves the most char. The very high heating rates appear to meld the phar.s of pyrolysis, and,.$s$ a result, it seems that the nain phase of pyroiysis has become extendea in ihe process. However, the total amount of $\mathrm{HCl}$ formed remained constant at the higher heating rates.

Figure 34 contrasts the thermograms of four rubber formulations heated in air of $20^{\circ} \mathrm{C} / \mathrm{min}$. The greatest difference appears in rubber-1? which is an insulation used for high-voltage cable. Degradation begins at $285^{\circ} \mathrm{C}$; however, the main degradation phase does not start until $415=C$ and this leads to a char residue of $54.5 \%$. Rubber- 1138 and -138 require $385^{\circ} \mathrm{C}$ and $388^{\circ} \mathrm{C}$, respectively, to start their main phases, but they leave a char residue of $11 \%$ and $25 \%$. All three formulations show very low $\mathrm{H}_{j} \mathrm{O}^{-}$production. As mentioned in our previous reports, the low amuunt of $\mathrm{HCl}$ and its detection at higher temperatures might be due to the preser.ce of $\mathrm{H}_{3} \mathrm{O}^{-}$acceptors such as $\mathrm{Sb}_{2} \mathrm{O}_{3}, \mathrm{MgO}$, or $\mathrm{ZnO}$, that react with the $\mathrm{HCl}$ evolved at lower temperatures. Rubber-1132 produces copious amounts of $\mathrm{HCl}$, leaves a low amount of char, and shows that its main degradation phase starts at a relatively low temperature.

The effect of higher heating rates, as shown in Table 11, is most pronounced on the decomposition rates in the main phase of pyrolysis which, in the case of rubber-12, occurs in the second phase of pyrolysis. In this series of formulations, the fastest degradation rates appear in rubber1132 , which is also a high $\mathrm{HCl}$ producer, and the lowest degradation rates appear in rubber-1138, which is a very low acid producer. Higher heating rates tend to blend all the phases together and the weight loss in the main phase, consequently, appears to be larger. Figure 35 further illustrates the effect of auditives on the degradation scheme of the insulations. Thus, rubber-12 shows an exotherm at $280^{\circ} \mathrm{C}$ that is probably due to decomposition of the metal oxide, an exotherm (which begins at $360^{\circ} \mathrm{C}$ ) that can be attributed to loss of water from $\mathrm{CaCO}_{3}$, and a series of exotherms that begin at $405^{\circ} \mathrm{C}$ and are attributed to decomposition of this insulation as well as the plasticizers. Rubber- 1138 shows an endotherm at $100^{\circ} \mathrm{C}$ that is 


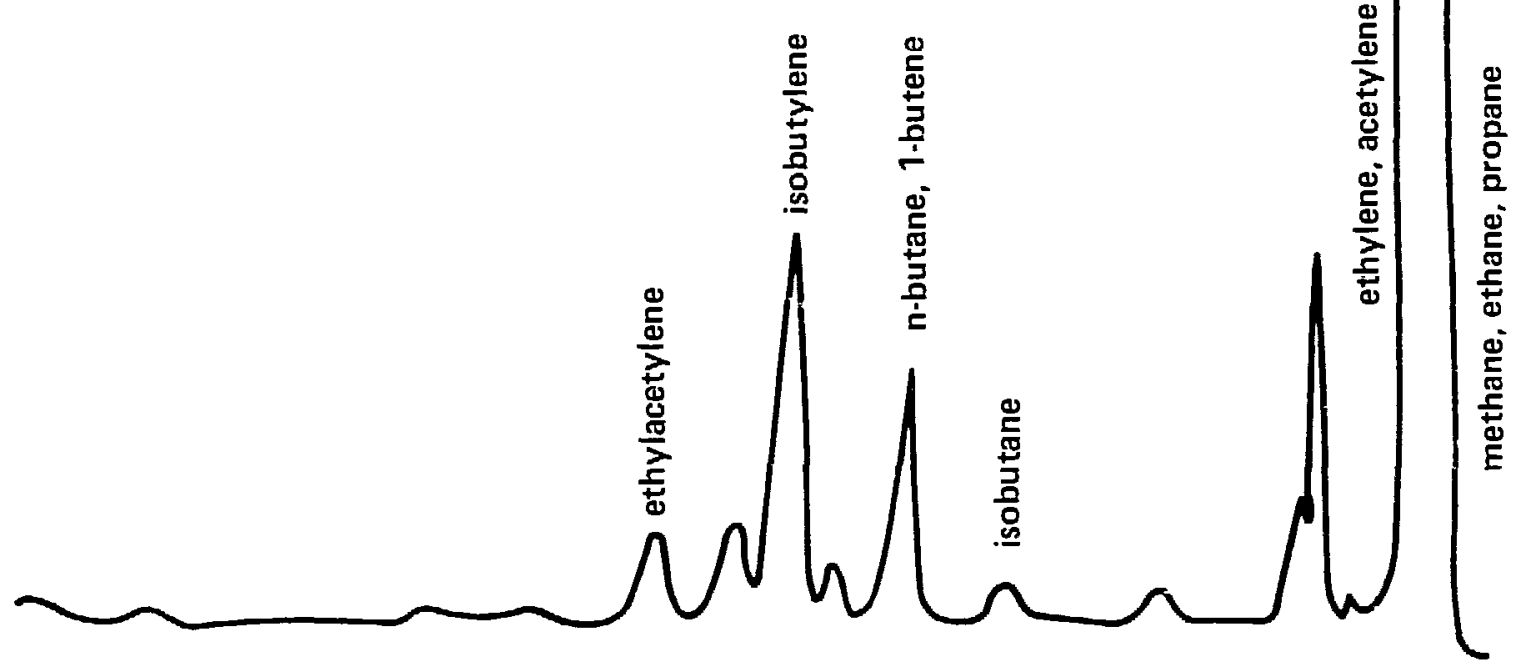

(b) PVC-104

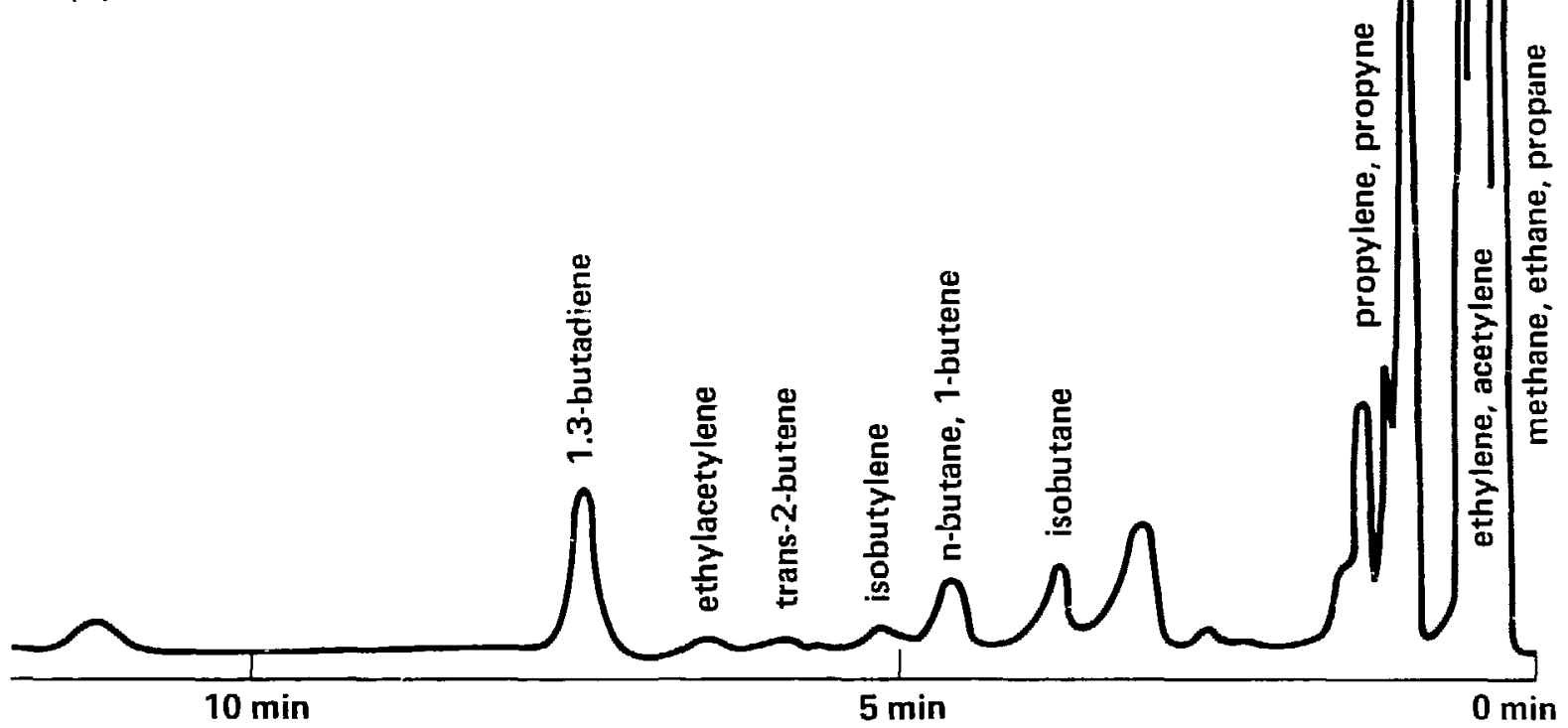

Figure 33. Comparison of gaseous degradation products of virgin PVC with those of PVC-104.

due to water and a series of exotherms beginning with one at $375^{\circ} \mathrm{C}$, which again could be due to loss of water from $\mathrm{CaCO}_{3}$, and several exotherms starting at $410^{\circ} \mathrm{C}$ that we attribute to dehydrochlorination of this insulation and degradation of the plasticizer. Rubber-138 shows an endotherm at $80^{\circ} \mathrm{C}$ that is moisture loss, an indication of an exotherm at $375^{\circ} \mathrm{C}$, again due to water loss from $\mathrm{CaCO}_{3}$, and an exotherm at $425^{\circ} \mathrm{C}$ that occurs in the dehydrochlorination region of the formulation. Rubber-1132, which is a high acid producer, has three exotherms: one at $287^{\circ} \mathrm{C}$, another starting at $318^{\circ} \mathrm{C}$ which we attribute to the degradation of the insulation and the plasticizer, and the third one at $425^{\circ} \mathrm{C}$ which we attribute to the oxidation of the highly crossed-linked region.

Results of the gas-chromatographic analysis of the gaseous products of virgin Neoprene and rubber-12 (which is a low acid producer) show the following hydrocarbons: methane, ethylene, acetylene, ethane, propane, propylene, propyne, isobutane, n-butane, 1-butene, isobutylene, 
Table 11. The effects of heating rates on the thermal degradation of various rubber insulations.

\begin{tabular}{|c|c|c|c|c|c|c|c|c|c|}
\hline \multirow[b]{2}{*}{ Sample } & \multirow[b]{2}{*}{$\begin{array}{l}\text { Heating } \\
\text { rate } \\
\left({ }^{\circ} \mathrm{C} / \mathrm{min}\right)\end{array}$} & \multicolumn{2}{|c|}{ Main phase-1st phase } & \multicolumn{2}{|c|}{ 2nd phase } & \multicolumn{2}{|c|}{ 3rd phase } & \multirow{2}{*}{$\begin{array}{l}\text { Wt luss } \\
\text { in main } \\
\text { phase } \\
(w)\end{array}$} & \multirow{2}{*}{$\begin{array}{c}\text { Char at end } \\
\text { of } \\
\text { pyroly'sis } \\
\text { (a) }\end{array}$} \\
\hline & & $\begin{array}{c}\text { Onset of } \\
\text { wt loss } \\
\left({ }^{\circ} \mathrm{C}\right)\end{array}$ & $\begin{array}{c}\text { Degradation } \\
\text { rate } \\
(\% / \mathrm{min})\end{array}$ & $\begin{array}{l}\text { Onset of } \\
\text { wt loss } \\
\left(^{\circ} \mathrm{C}\right)\end{array}$ & $\begin{array}{c}\text { Degradation } \\
\text { rate } \\
(r / \mathrm{min})\end{array}$ & $\begin{array}{c}\text { Onset of } \\
w t \text { loss } \\
\left({ }^{\circ}\right)\end{array}$ & $\begin{array}{c}\text { Degradation } \\
\text { rate } \\
(\because / \mathrm{min})\end{array}$ & & \\
\hline \multirow{5}{*}{ Neoprene-007 } & 10 & 290 & 7.0 & 495 & 11.0 & 578 & 2.0 & 5 & $25^{4}$ \\
\hline & 20 & 300 & 13.0 & 512 & 12.5 & 608 & 10.0 & 11 & 24.5 \\
\hline & 40 & 305 & $21 / 6 s^{b}$ & 403 & 11.0 & 575 & 8.0 & 22 & 22.0 \\
\hline & 80 & 305 & $27 / 6 s^{b}$ & 485 & 29.0 & 630 & 17.5 & 18 & 20.0 \\
\hline & 160 & 290 & $24 / 3 s^{b}$ & 425 & 25.0 & 622 & 22.0 & 25 & 21.0 \\
\hline \multirow[t]{5}{*}{ Neoprene-84 } & 10 & 235 & 3.0 & 355 & 1.5 & 498 & 12.0 & 4 & $48^{\prime}$ \\
\hline & 20 & 238 & 5.0 & 325 & 3.5 & 505 & 14.0 & 4 & 44 \\
\hline & 40 & 240 & 8,0 & 340 & 5.0 & 520 & 15.5 & 7 & 46 \\
\hline & 80 & 260 & 38.0 & 360 & 20.0 & 560 & 19.0 & 9 & 44 \\
\hline & 160 & 260 & $11 / 6 \mathrm{~s}^{\mathrm{b}}$ & 380 & 36.0 & 588 & 15.0 & 10 & 44 \\
\hline \multirow[t]{5}{*}{ Neoprene-435 } & 10 & 283 & 11.5 & 368 & 1.5 & 480 & 13.5 & 7 & $7.5^{d}$ \\
\hline & 20 & 308 & 27.0 & 387 & 2.0 & 522 & 14.0 & 15 & 6.0 \\
\hline & 40 & 310 & & 390 & 3.9 & 445 & 17.0 & 27.5 & 7.0 \\
\hline & 80 & 310 & & \multicolumn{2}{|c|}{ blends with 3rd phase } & 440 & 28.5 & 30.0 & 12.0 \\
\hline & 160 & 300 & & \multicolumn{2}{|c|}{ blends with 3rd phase } & 420 & 33.5 & 36.0 & 17.0 \\
\hline \multirow[t]{5}{*}{ Rubber-134 } & 10 & 248 & 3.5 & 420 & 1.7 & & & 38 & $8^{\prime \prime}$ \\
\hline & 20 & 240 & 14.5 & 410 & 2.4 & & & 31 & 26 \\
\hline & 40 & 230 & 37.8 & 400 & 6.5 & & & 39 & 11.5 \\
\hline & 80 & 260 & 68 & 405 & 10 & & & 51 & 11 \\
\hline & 160 & 290 & $55 / 30 \mathrm{~s}^{1}$ & 380 & 21.5 & & & 56 & 12.5 \\
\hline Virgin & 10 & 323 & 8.0 & 410 & 4.0 & 480 & 15.0 & 16 & $2.0^{4}$ \\
\hline \multirow[t]{4}{*}{ polychloroprene } & 20 & 325 & 16.0 & 425 & 7.0 & 500 & 16.0 & 20 & 1.0 \\
\hline & 40 & 309 & 47.1 & 400 & 17.0 & 485 & 25.0 & 25 & 1.0 \\
\hline & 80 & 315 & 56.0 & 430 & 17.0 & 540 & 22.0 & 35 & 0 \\
\hline & 160 & 310 & $39.5 / 10 \mathrm{~s}^{\prime \prime}$ & 415 & 20.0 & 530 & 30.0 & $-\mu$ & \\
\hline \multirow[t]{5}{*}{ Rubber-1138 } & 10 & 380 & 7.0 & 470 & 10.0 & 510 & 30.0 & 20 & $10^{\mathrm{ln}}$ \\
\hline & 20 & 385 & 12.0 & 190 & 21.0 & & & 2.3 & 11 \\
\hline & 40 & 370 & 21 & 510 & 20.0 & & & 33 & 8.3 \\
\hline & 80 & 368 & 36 & 530 & 24 & & & 27 & 17.7 \\
\hline & 160 & 325 & 33 & 530 & 30 & & & $3 B$ & 18 \\
\hline
\end{tabular}


Table 11. (Continued)

\begin{tabular}{|c|c|c|c|c|c|c|c|c|c|}
\hline \multirow[b]{2}{*}{ Sample } & \multirow[b]{2}{*}{$\begin{array}{l}\text { Heating } \\
\text { rate } \\
\left({ }^{\circ} \mathrm{C} / \mathrm{min}\right)\end{array}$} & \multicolumn{2}{|c|}{ Main phase-1st phase } & \multicolumn{2}{|c|}{ 2nd phase } & \multicolumn{2}{|c|}{ 3rd phase } & \multirow{2}{*}{$\begin{array}{c}\text { Wt loss } \\
\text { in main } \\
\text { phase } \\
(\%)\end{array}$} & \multirow{2}{*}{$\begin{array}{c}\text { Char at end } \\
\text { of } \\
\text { pyrolysis } \\
(\%)\end{array}$} \\
\hline & & $\begin{array}{l}\text { Onset of } \\
\text { wt loss } \\
\left({ }^{\circ} \mathrm{C}\right)\end{array}$ & $\begin{array}{c}\text { Degradation } \\
\text { rate } \\
(\% / \mathrm{min})\end{array}$ & $\begin{array}{c}\text { Onsel of } \\
w t \text { loss } \\
\left(^{\circ} \mathrm{C}\right)\end{array}$ & $\begin{array}{c}\text { Degradation } \\
\text { rate } \\
(\% / \mathrm{min})\end{array}$ & $\begin{array}{c}\text { Onset of } \\
\text { wt loss } \\
\left({ }^{\circ} \mathrm{C}\right)\end{array}$ & $\begin{array}{c}\text { Degradation } \\
\text { rate } \\
(\% / \mathrm{min})\end{array}$ & & \\
\hline \multirow[t]{5}{*}{ Rubber-1132 } & 10 & 255 & 12 & 390 & $1.5^{i}$ & & & 22 & $15.3^{i}$ \\
\hline & 20 & 250 & 19 & 395 & 3.3 & & & 28 & 13.8 \\
\hline & 40 & 245 & 38 & 392 & 7.0 & & & 35 & 15 \\
\hline & 80 & 270 & 76 & 405 & 13.5 & & & 40 & 13 \\
\hline & 160 & 280 & $21 / 18 s^{b}$ & 390 & 21.0 & & & 44 & 20 \\
\hline \multirow[t]{5}{*}{ Rubber-138 } & 10 & 390 & 7 & 490 & 25 & & & 21 & $22^{k}$ \\
\hline & 20 & 388 & 10 & 493 & 25 & & & 19 & 25 \\
\hline & 40 & 380 & 27 & 505 & 20 & & & 30 & 20 \\
\hline & 80 & 380 & 48 & 520 & 24 & & & $\mathbf{3 8}$ & 9 \\
\hline & 160 & 340 & 74 & 510 & 24 & & & 50 & 9 \\
\hline \multirow[t]{5}{*}{ Rubber-12' } & 10 & 260 & 1 & 417 & 32 & & & 14 & $54.5^{\mathrm{m}}$ \\
\hline & 20 & 285 & 3 & 415 & 25 & & & 22 & 54.5 \\
\hline & 40 & 280 & 5 & 395 & 37 & & & 21 & 54.5 \\
\hline & 80 & & & 395 & 46 & & & 24 & 57.3 \\
\hline & 160 & & & 370 & $25 / 36 s^{n}$ & & & 27 & 57.3 \\
\hline
\end{tabular}

${ }^{2} \mathrm{PH}$ change in main phase for Neoprene-007 that occurred at 10 and $20^{\circ} \mathrm{C} / \mathrm{min}$ was 7.18 and 3.96 , respectively.

${ }^{6}$ Degradation rate took less than 1 minute (example: $21 \%$ in 6 seconds).

' $\mathrm{pH}$ change in main phase for Neoprene-84 that occurred at 10 and $20^{\circ} \mathrm{C} / \mathrm{min}$ was 7.14 and 5.10 , respectively.

${ }^{d} \mathrm{pH}$ change in main phase for Neoprene 435 that occurred at 10 and $20^{\circ} \mathrm{C} / \mathrm{min}$ was 7.1 and 3.39 , respectively.

' $\mathrm{pH}$ change in main phase for rubber-134 that occurred at 10 and $20^{\circ} \mathrm{C} / \mathrm{min}$ was 7.07 and 4.48 , respectively.

${ }^{f} \mathrm{pH}$ change in main phase for virgin polychloroprene that occurred at 10 and $20^{\circ} \mathrm{C} / \mathrm{min}$ was 7.28 and 3.85 , respectively.

B $\mathrm{pH}$ change at 45.

h Low acid.

'There was no third phase for rubber-1132, -138 , or -12 .

1 High acid.

" $\mathrm{pH}$ change in main phase that occurred at 10 and $20^{\circ} \mathrm{C} / \mathrm{min}$ was 7.23 and 6.58 , respectively.

' Second phase became the main phase.

${ }^{m}$ pH change in main phase that occurred at 10 and $20^{\circ} \mathrm{C} / \mathrm{min}$ was 7.19 and 7.00 , respectively.

"Degradation raie occurred in less than 1 minute (example: $25 \%$ in 36 seconds). 


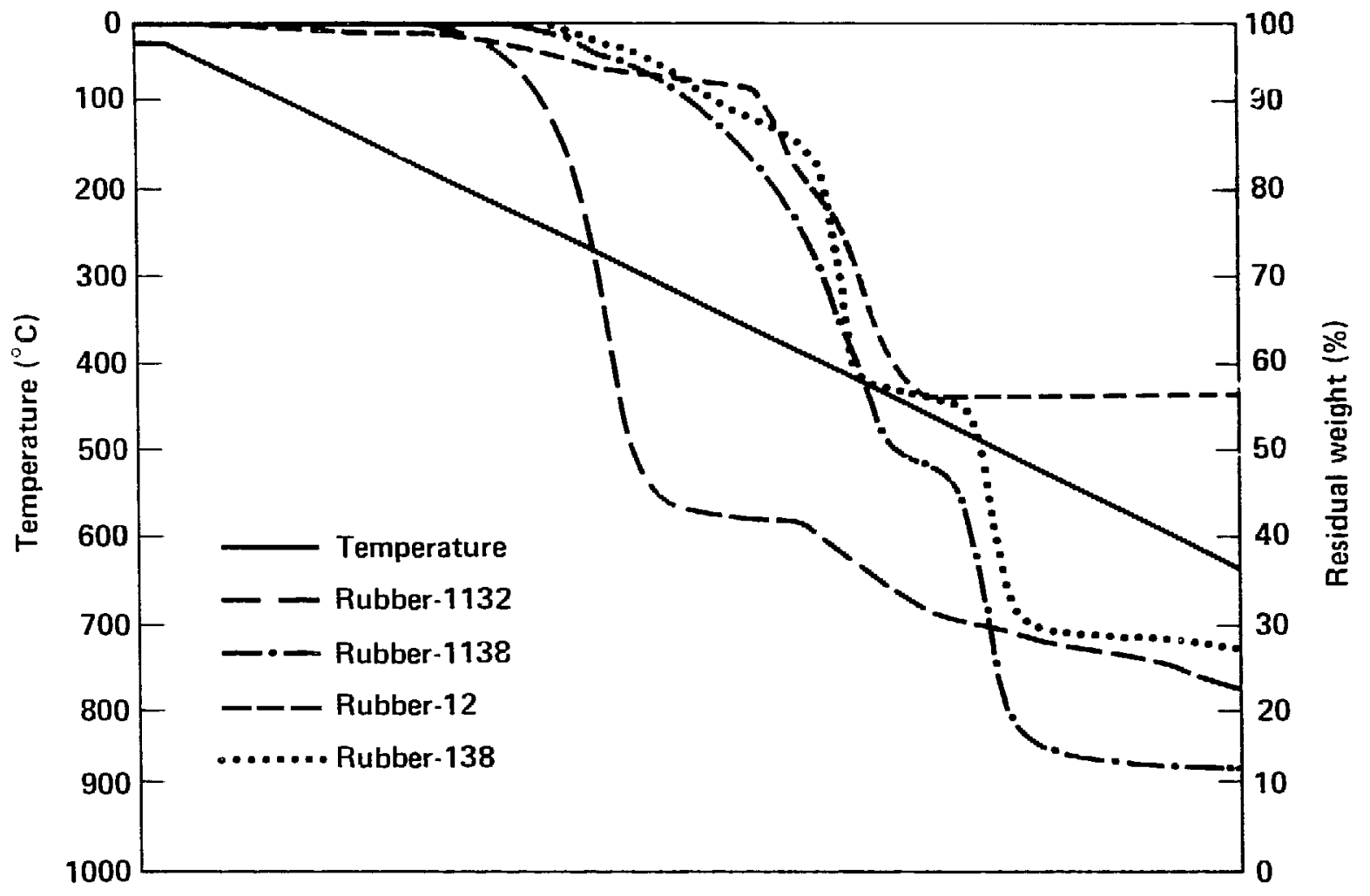

Figure 34. Thermograms of rubber insulations heated in air at $20^{\circ} \mathrm{C} / \mathrm{min}$.

cis-2-butene, trans-2 butene, ethylacetylene, 1.3-butadiene and 4-methyl-pentene-1. The two insulations also formed 4-methyl-pentene-2 and cis-hexene-2. The virgin neoprene produced approximately four times as much of the light hydrocarbons as did the insulations. Results of the gas-chromatographic, mass-spectrometric analysis of the liquid pyrolyzates from Neoprene-007, -84 . -435 and Rubber-134 on a Carbowax-20M fusedsilica capillary column have been presented previously. ${ }^{3}$ Additional analysis results of virgin Neoprene, Neoprene-007 and Neoprene-435 pyrolyzates were obtained from the SE-54 fusedsilica column and are presented in Appendix $B$ (Figs. B5-B7). Our chromatograms showed additional aromatic and polycyclic compounds previously undetected on the Carbowax-20M column. These are substituted benzenes and naphthalenes as well as other cyclic compounds. As expected, the insulations show such products as substituted phthalates and adipates which are degradation products of the plasticizers used in the formulations.

The results of the gas-chromatographic, mass-spectrometric analysis of the liquidpyrolyzate cable formulations rubber-12, -138 , and -1138 are shown in Appendix B (Figs. B8$B 10)$. The pyrolyzates of rubber- 12 and -138 show high molecular-weight hydrocarhons as well as some aromatic compounds. In addition, rubber138 shows palmitic acid and dioctylphthalate. which are degradation products of the plasticizers. The degradation products of rubber-1138 were generated in our large-scale test cell. They were collected on glass wool at one of the exits in the ductway, extracted in the Soxhlet extractor with $50 \mathrm{ml}$ dichloroethylene, concentrated to $3 \mathrm{ml}$ and injected in an SE-30 fused-silica capillary column. The liquid pyrolyzate contained high molecularweight aliphatic hydrocarbons, breakdown products of phthalates and adipates which are used as plasticizers, as well as alkyl phosphates and silicates which are breakdown products of the flame retardants incorporated in these formulations.

\section{Polyethylene}

The polyethvlene insulations used in our experiments were designed for small signal wires. The TGAs of the polyethylene insulations show several stages of pyrolysis that suggests the polyethylene used in these formulations is a lowdensity, highly branched polymer (Fig. 36). The 


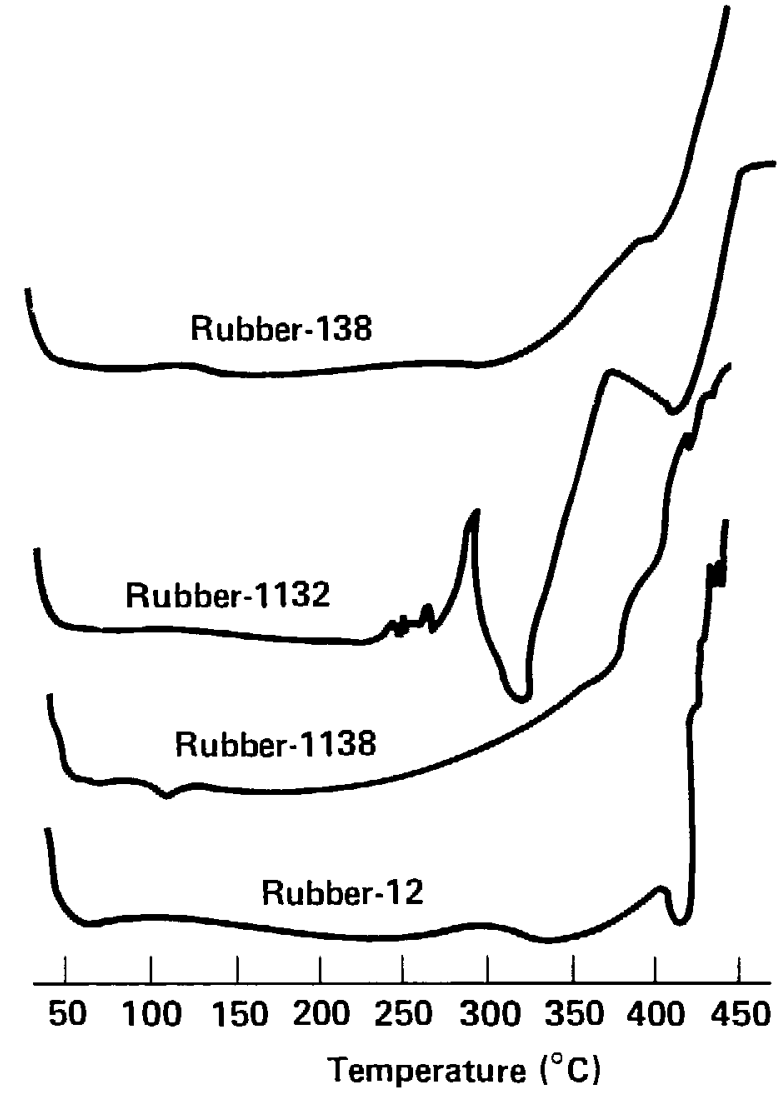

Figure 35. DSCs of rubber insulation heated in air at $20^{\circ} \mathrm{C} / \mathrm{min}$.

first stages of pyrolysis between $230^{\circ} \mathrm{C}$ and $325^{\circ} \mathrm{C}$ are due to the destruction of the branching points. ${ }^{9}$ Higher temperatures between $325-365^{\circ} \mathrm{C}$ lead to chain scission and molecular enlargement, both of which occur simultaneously. Chain scission occurs via inter- and intramolecular hydrogen abstractions, and it is responsible for the formation of low molecular-weight compounds as well as other pyrolyzates. 9.10 Molecularenlargement reactions, due to the combination of alkyl radicals, cause an increase in the long-chain, branched material. The last stage of pyrolysis in the range of $350^{\circ}$ to $470^{\circ} \mathrm{C}$ is due to degradation of the polymer's char-like residue.

In comparing the degradation mode of the polyethylene-77 and -95 to that of virgin polyethylene, we see the degradation rate of the insulation in the initial stage of pyrolysis is slightly lower than that of the virgin polyethylene. However, the degradation rate of the polyethylene insulation in the active pyrolysis region is slightly higher than that of the virgin polyethylene. The oxidation of the polyethylene insulations char like residue begins at a slightly higher temnerature than that of the virgin polymer. We attribs.te these differences to the additives incorporated into the insulation.

The effects of heating rates on the degradation of polyethylene-77, -95, and virgin polyethylene are summarized in Table 12. As expected, higher heating rat's increase the degradation rates of all three formulations. Higher heating rates also increase the overall weight loss in the active pyrolysis region and therefore delay the onset of the third major phase of pyrolysis. Heating rates higher than $40^{\circ} \mathrm{C} / \mathrm{min}$ meld the three major phases of pyrolysis into essentially one major phase that leaves no residue at the end of pyrolysis. We also found that heating rates of $40=\mathrm{C} / \mathrm{min}$ and higher decrease the temperature responsible for initial degradation as well as the active pyrolysis region of polyethylene-95. However, the same heating rates increase the temperature leading to initial degradation of poly'ethylene-77. and their effect is inconsistent on both the initial and the active pyrolysis region of virgin polyethylene.

DSCA results of polyethylene-95 in air showed an endotherm at $100^{\circ} \mathrm{C}$. which we attributed to melting, and an exotherm at $224^{\circ} \mathrm{C}$, which was due to oxidation, as evidenced by a slight weight gain in that regiun in our thermogravimetric experiments (Fig. 37). Another exotherm at $327^{\circ} \mathrm{C}$ appeared in the active pyrnl:sis region and corresponded to thermal decomposition. Polyethylene-77 showed an endutherm at $106^{\circ} \mathrm{C}$, an oxidation exotherm at $258^{\circ} \mathrm{C}$, and an exotherm at $315^{\circ} \mathrm{C}$, which is the beginning of the active pyrolysis region. Virgin polyethylene also showed an endotherm at $100^{\circ} \mathrm{C}$, an exotherm at $246^{\circ} \mathrm{C}$, and a thermal degradation exotherm at $350^{\circ} \mathrm{C}$. The slightly lower exotherms exhibited by polyethylene- 95 is attributed to the additives.

The results of the analysis of the gaseous pyrolyzates of polyethylene-95 showed large amounts of methane, ethylene, acetylene, ethane, propane, propylene, propyne, n-butane and butene. In addition, the mixture showed some isobutylene, 1,3-butadiene, cis-2-butene, pentane, 4-methyl-pentene-1, and cis-hexene- 2 .

In contrast, virgin polvethylene showed copious amounts of all of the above identified $C_{1}-C_{n}$ hydrocarbons as well as some as vet unidentified hydrocarbon-type compounds. The constituents of the liquid pyrolyzates, shown in Appendix B (Figs. B11-B13), are long-chain saturated and unsaturated hydrocarbons and high molecularweight aldehydes, alcohols, and esters. 


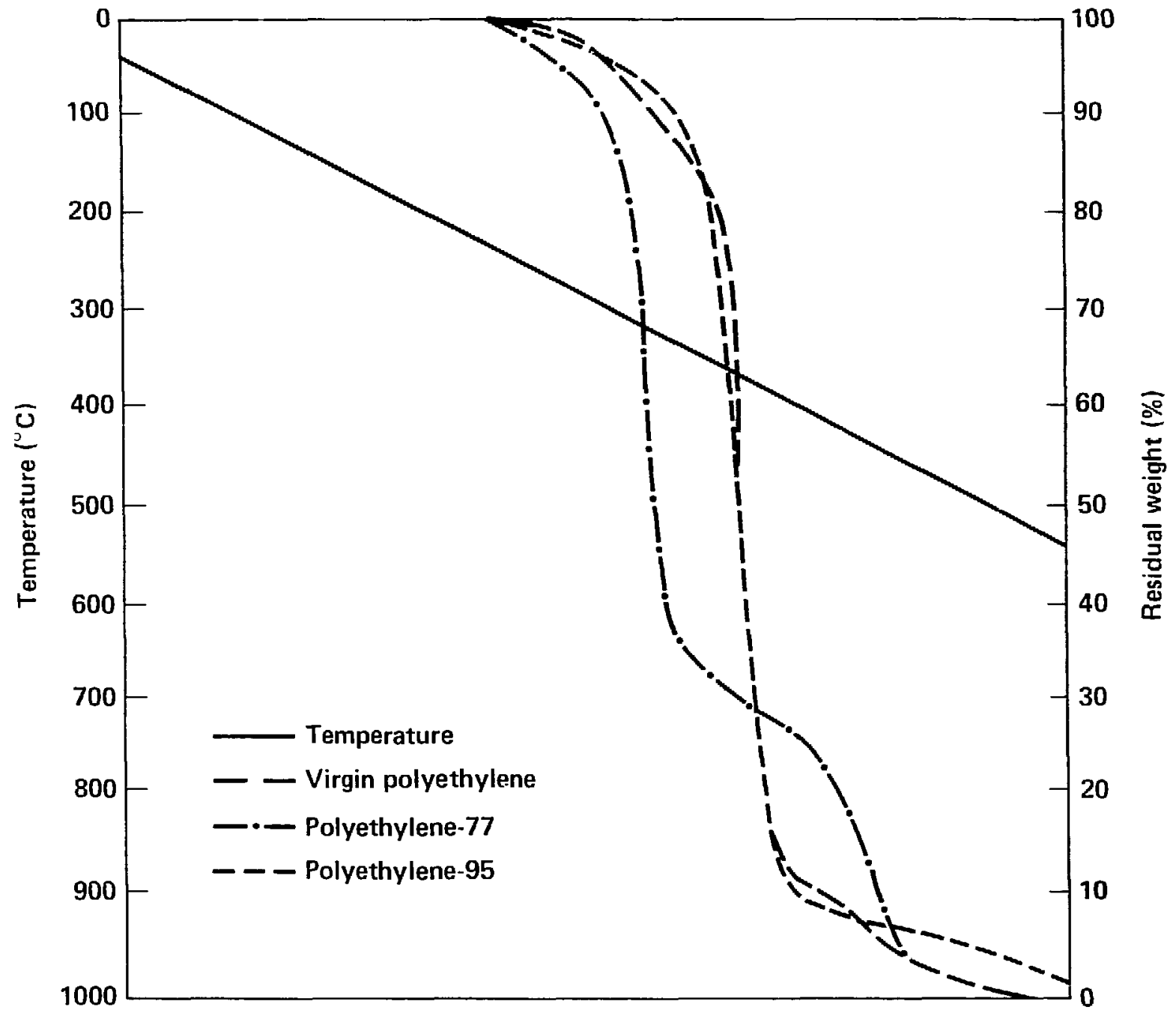

Figure 36. Thermograms of polyethylene heated in air at $20^{\circ} \mathrm{C} / \mathrm{min}$.

Polyethylene-95 also showed di-n-butylphthalate among its degradation products, which is due to the degradation of the plasticizer.

\section{Polypropylene}

We used polypropylene insulation designed for fiber optics' use.

Thermal decomposition of polypropylene involved both chain-scission and chain-transfer reactions as does polyethylene. In this polymer, every other carbon atom is tertiary, and thus both tertiary $\mathrm{C}-\mathrm{H}$ bonds and all $\mathrm{C}-\mathrm{C}$ bonds are readily susceptible to attack. TGA results of both the polypropylene-90 and the virgin polypropylene showed essentially one main phase of pyrolysis that, at a heating rate of $10^{\circ} \mathrm{C} / \mathrm{min}$, began at $250^{\circ} \mathrm{C}$ for both the insulation and the virgin poly- mer (Table 13). The main degradation phase was preceded by an induction period and followed by a short weight-loss region that was due to ignition of the carbonacecus residue. The oxidation of the carbonaceous residue began at lower temperatures when the samples were heated at a rate of 10 and $20^{\circ} \mathrm{C} / \mathrm{min}$, and, at the end of pyrolysis in the case of polypropylene-90, resulted in a char content of $3.5 \%$ and $7 \%$, respectively. Virgin polypropylene leaves no char at the same heating rates. The degradation of the char of both the insulation and virgin polypropylene at heating rates of $40^{\circ} \mathrm{C} / \mathrm{min}$ and above began at higher temperatures and left no char at the end of pyrolysis. The temperature leading to initial degradation of virgin polypropylene remained unaffected by higher heating rates. Polypropylene- 90 had to be heated 
Table 12. The effect of heating rate on the thermal degradation of polyethylene.

\begin{tabular}{|c|c|c|c|c|c|c|c|c|}
\hline \multirow[b]{2}{*}{ Sample } & \multirow[b]{2}{*}{$\begin{array}{l}\text { Heating } \\
\text { rate } \\
\left({ }^{\circ} \mathrm{C} / \mathrm{min}\right)\end{array}$} & \multicolumn{2}{|c|}{ Main phase-1st phase } & \multicolumn{2}{|c|}{ 2nd phase } & \multicolumn{2}{|c|}{ 3rd phase } & \multirow{2}{*}{$\begin{array}{c}\text { Wt loss } \\
\text { in main } \\
\text { phase } \\
(7)\end{array}$} \\
\hline & & $\begin{array}{l}\text { Onset of } \\
\text { wi loss } \\
\left({ }^{\circ} \mathrm{C}\right)\end{array}$ & $\begin{array}{c}\text { Degradation } \\
\text { rate } \\
(\% / m i n)\end{array}$ & $\begin{array}{c}\text { Onset of } \\
\text { wl loss } \\
\left({ }^{\circ} \mathrm{C}\right)\end{array}$ & $\begin{array}{c}\text { Degradation } \\
\text { rate } \\
(\% / \mathrm{min})\end{array}$ & $\begin{array}{l}\text { Onset of } \\
\text { wt loss } \\
\left({ }^{\circ} \mathrm{C}\right)\end{array}$ & $\begin{array}{c}\text { Degradalion } \\
\text { rate } \\
(\% / \mathrm{min})\end{array}$ & \\
\hline \multirow[t]{5}{*}{ Polyethylene-95 } & 10 & 250 & 0.75 & 325 & 21 & 350 & rate of & $35^{4}$ \\
\hline & 20 & 250 & 1.5 & 350 & 45 & 380 & degree & b3 \\
\hline & 40 & 230 & 4.0 & 330 & 65 & 380 & impossible & 60 \\
\hline & 80 & 235 & 5.5 & 330 & 85 & 450 & to & 86 \\
\hline & 160 & 230 & 14 & 320 & 98 & 450 & determine & 89 \\
\hline \multirow[t]{5}{*}{ Polyethylene-77 } & 10 & 235 & 1.5 & 335 & 10.5 & 350 & rate of & $11^{b}$ \\
\hline & 20 & 245 & 3.0 & 315 & 52 & 358 & degree & 35 \\
\hline & 40 & 250 & 7 & 320 & 86 & phase & impossible & 70 \\
\hline & 80 & 260 & 13.5 & 335 & 80 & disappears & to & 80 \\
\hline & 160 & 285 & $\begin{array}{c}\text { phase } \\
\text { disappears }\end{array}$ & $\begin{array}{c}\text { phase } \\
\text { disappears }\end{array}$ & $\begin{array}{c}\text { phase } \\
\text { disappears }\end{array}$ & & determine & 95 \\
\hline \multirow[t]{5}{*}{ Virgin polyethylene } & 10 & 250 & 1.5 & 325 & 15 & 360 & rate of & $50^{\prime}$ \\
\hline & 20 & 270 & 1.8 & 345 & 46 & 370 & degree & 58 \\
\hline & 40 & 245 & 4.0 & 348 & 70 & 375 & impossible & 62 \\
\hline & 80 & 290 & 8.5 & 340 & 76 & 430 & 10 & 82 \\
\hline & 160 & 250 & 17 & 310 & 98 & 430 & determine & 93 \\
\hline
\end{tabular}

'At $10^{\circ} \mathrm{C} / \mathrm{min}$., there was less than $0.5 \%$ char for polyethylene-95. By $20^{\circ} \mathrm{C} / \mathrm{min}$., there was no char at all.

${ }^{b} \mathrm{pH}$ change that occurred in main phase at 10 and $20^{\circ} \mathrm{C} / \mathrm{min}$ was 7.10 and 6.77 , respectively.

' $\mathrm{pH}$ change that occurred in main phase at 10 and $20^{\circ} \mathrm{C} / \mathrm{min}$ was 7.15 and 6.73 , respectively. 


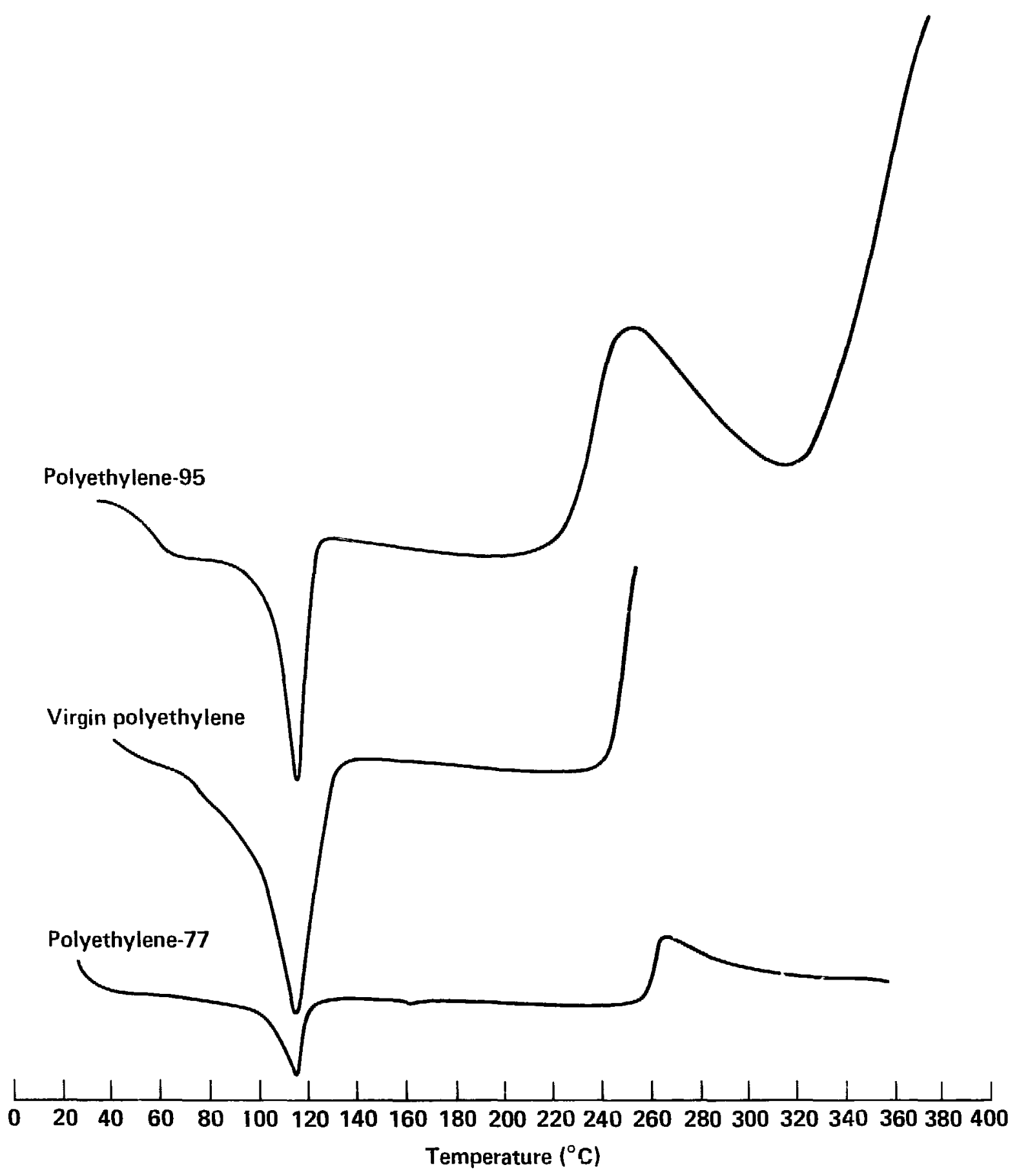

Figure 37. DSCA of virgin polyethylene, polyethylene-77, and polyethylene-95 heated in air at $20^{\circ} \mathrm{C} / \mathrm{min}$.

to $382^{\circ} \mathrm{C}$ when heated at a rate of $80^{\circ} \mathrm{C} / \mathrm{min}$, and to $370^{\circ} \mathrm{C}$ when heated at $160^{\circ} \mathrm{C} / \mathrm{min}$, to cause initial degradation. The rates of degradation in the main phase of pyrolysis of both the insulation and the virgin polypropylene increased with higher heating rates. Polypropylene- 90 degraded faster at higher heating rates than did the virgin polypropylene at identical heating rates (Fig. 38).

DSCA at $20^{\circ} \mathrm{C} / \mathrm{min}$ in air showed an endotherm at $144^{\circ} \mathrm{C}$ for both the polypropylene- 90 and virgin polypropylene which we attributed to melting. Polypropylene-90 showed an exotherm at 
Table 13. The effects of heating rate on the thermal degradation of polypropylene.

\begin{tabular}{|c|c|c|c|c|c|c|c|}
\hline \multirow[b]{2}{*}{ Sample } & \multirow[b]{2}{*}{$\begin{array}{l}\text { Heating } \\
\text { rate } \\
\left({ }^{\circ} \mathrm{C} / \mathrm{min}\right)\end{array}$} & \multicolumn{2}{|c|}{ Main phase-1st phase } & \multicolumn{2}{|c|}{ 2nd phase } & \multirow{2}{*}{$\begin{array}{c}\text { We loss } \\
\text { in main } \\
\text { phase } \\
(?,)\end{array}$} & \multirow{2}{*}{$\begin{array}{c}\text { Char al end } \\
\text { of } \\
\text { pyrolysis } \\
(\text { if })\end{array}$} \\
\hline & & $\begin{array}{c}\text { Onset of } \\
\text { wt loss } \\
\left({ }^{\circ} \mathrm{C}\right)\end{array}$ & $\begin{array}{c}\text { Degradation } \\
\text { rate } \\
(\% / \mathrm{min})\end{array}$ & $\begin{array}{c}\text { Onset of } \\
\text { wt loss } \\
\left({ }^{\circ} \mathrm{C}\right)\end{array}$ & $\begin{array}{c}\text { Degradation } \\
\text { rate } \\
(7 / \mathrm{min})\end{array}$ & & \\
\hline \multicolumn{8}{|c|}{ Polypropylene-90 } \\
\hline & 10 & 250 & 14 & 300 & impossible & 60 & $3.5^{+}$ \\
\hline & 20 & 250 & 24 & 320 & to determine & 69 & 3.0 \\
\hline & 40 & 240 & 59 & 325 & rate as phase & 82 & 0 \\
\hline & 80 & 382 & $50 / 30 s^{b}$ & 450 & consists of & 70 & $\mathbf{0}$ \\
\hline & 160 & 370 & $75 / 18 s^{b}$ & 450 & $\begin{array}{l}\text { several } \\
\text { sub-phases }\end{array}$ & 77 & $\mathbf{0}$ \\
\hline \multicolumn{8}{|c|}{ Virgin polypropylene } \\
\hline & 10 & 250 & 18 & 295 & impossible & 60 & $\mathbf{0}$ \\
\hline & 20 & 250 & 33 & 304 & to determine & 81 & o \\
\hline & 40 & 250 & 55 & 330 & rate as phase & 79 & 0 \\
\hline & 80 & 250 & 80 & 350 & consists of & 93 & 0 \\
\hline & 160 & 250 & $95 / 30 s^{b}$ & $\begin{array}{c}\text { phase } \\
\text { disappears }\end{array}$ & $\begin{array}{l}\text { several } \\
\text { sub-phases }\end{array}$ & 96 & 0 \\
\hline
\end{tabular}

${ }^{\mathrm{pH}} \mathrm{phange}$ that occurred at 10 and $20 \mathrm{C} / \mathrm{min}$ was 7.17 and 6.95 , respectively.

'Degradation rate took less than 1 minute (example: 50r' in 30 seconds).

$250^{\circ} \mathrm{C}$, which was the beginning of thermal degradation, two small exotherms at $295^{\circ} \mathrm{C}$ and $302^{\circ} \mathrm{C}$ which we attributed to degradation of the additives, and an exotherm at $350^{\circ} \mathrm{C}$ which was due to oxidation of the carbonaceous residue. Virgin polypropylene showed a slight oxidation exotherm at $216^{\circ} \mathrm{C}$, evidenced by the weight gain shown by the TGA; another exotherm at $250^{\circ} \mathrm{C}$ corresponded to the initial degradation, and there was another exotherm at $340^{\circ} \mathrm{C}$ which again was due to the oxidation of the carbonaceous residue (Fig. 39).

In addition to the $C_{1}-C_{6}$ hydrocarbons, which are the major degradation components, the liquid pyrolyzate portion of polypropylene- 90 and virgin polypropylene consisted predominantly of saturated and unsaturated ketones, tetrahydrofuran derivative and aldehydes. Results of the chromatograms are shown in Appendix B (Figs. B14 and B15).

\section{Polyurethane}

We used polyurethane insulation designed for use in fiber optics.

Our TGA results on polyurethane insulation indicated a two-step weight loss pattern (Fig. 40). The major weight-loss phase is preceded by an induction phase which, at a heating rate of $20^{\circ} \mathrm{C} / \mathrm{min}$, started at $260^{\circ} \mathrm{C}$ and ended at $271^{\circ} \mathrm{C}$.
The first phase, which began at $271^{\circ} \mathrm{C}$. is due to the loss of lower molecular-weight polyols and aliphatic fragments that formed on polymer degradation. The char remaining after the first phase was derived primarily from thermally stable polyisocyanates. The second phase that started at $332^{\circ} \mathrm{C}$ involved thermo-oxidative degradation of the char. The char content at completion of pyrol$y$ sis was $1.0 \%$.

The effect of heating rate on the degradation rate of this insulation is summarized in Table 14 . We see that the effect of high heating rates is consistent for the first phase of pyrolysis. The temperature responsible for the onset of the second phase of pyrolysis remains essentially constant up to $80^{\circ} \mathrm{C} / \mathrm{min}$. At this heating rate, and at $160^{\circ} \mathrm{C} / \mathrm{min}$, the temperature responsible for tite second phase is considerably higher than that seen at the lower heating rates. The degradation rate is considerably higher in the first phase of pyrolysis than in the second phase. The degradation rates in both phases increased with the increasing heating rates. The char content remained the same at all heating rates.

DSCA measurements showed two small endotherms at $80^{\circ} \mathrm{C}$ and $105^{\circ} \mathrm{C}$ which we assigned to the glass transition temperatures of the hard and soft segments of the polvurethane formulation (Fig. 41). A wide endotherm at $170^{\circ} \mathrm{C}$ was due 


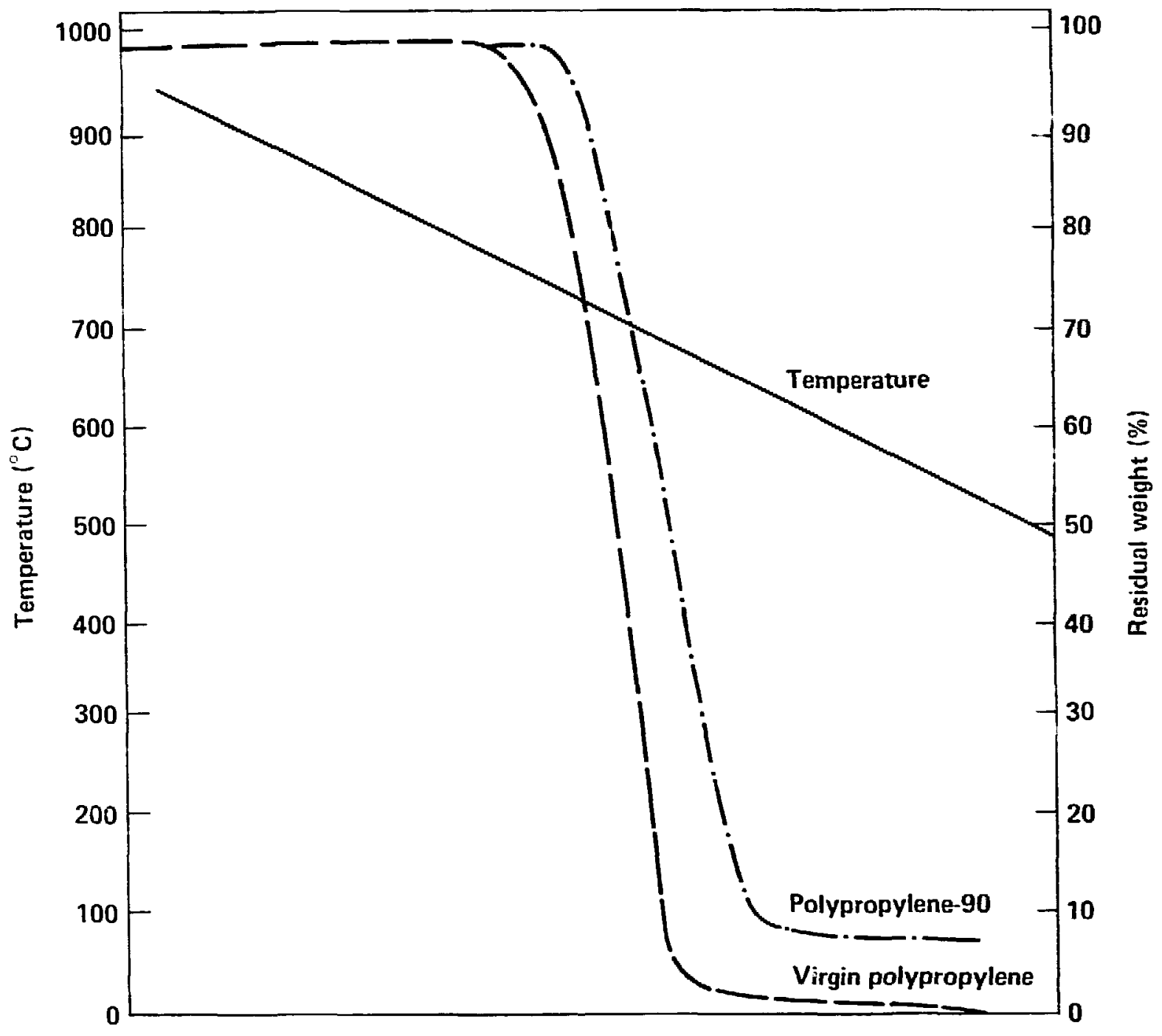

Figure 38. Thermograms of virgin polypropylene and polypropylene-90 heated in air at $20^{\circ} \mathrm{C} / \mathrm{min}$.

to the melting of the insulation. An endotherm at $260^{\circ} \mathrm{C}$, which appeared just before the main decomposition phase, was probably due to activation of the weak links and eventual scission of the bonds. An exotherm which started at $292^{\circ} \mathrm{C}$ is attributed to oxidation and/or recombination of radicals. We assigned the exotherm at $335^{\circ} \mathrm{C}$, which corresponds to the second phase of pyrolysis, to the oxidation of the char.

The Carbowax-20M results on the liquid pyrolyzate indicated the presence of alcohols, ketones, hydrocarbons, 1,4 butanediol, dodecan-6,7dione, and aniline. Constituents of the gaseous pyrolyzates contained large quantities of ethylene, ethane, acetylene, propane, propylene, propyne, isobutylene, trans-2-butene, and ethylacetylene.
There was some 1,3-butadiene, pentane, and 4-methyl-pentene-1. In addition, other researchers have reported formation of hydrogen cyanide. carbon monoxide, and nitrogen oxide. ${ }^{11}$ The amounts of hydrogen cyanide and carbon monoxide formed during pyrolysis have been reported to increase between 300 and $700^{\circ} \mathrm{C}$.

\section{Nylon}

Here, we used insulation designed for use in hook-up wires.

TGA curves showed an initial phase of low weight loss ending with 3 total weight loss of $5 \%$ at $350^{\circ} \mathrm{C}$ (Fig. 42). We attribute this weight loss mainly to absorbed water. Our DSCA study showed two events in this phase: an endotherm at 


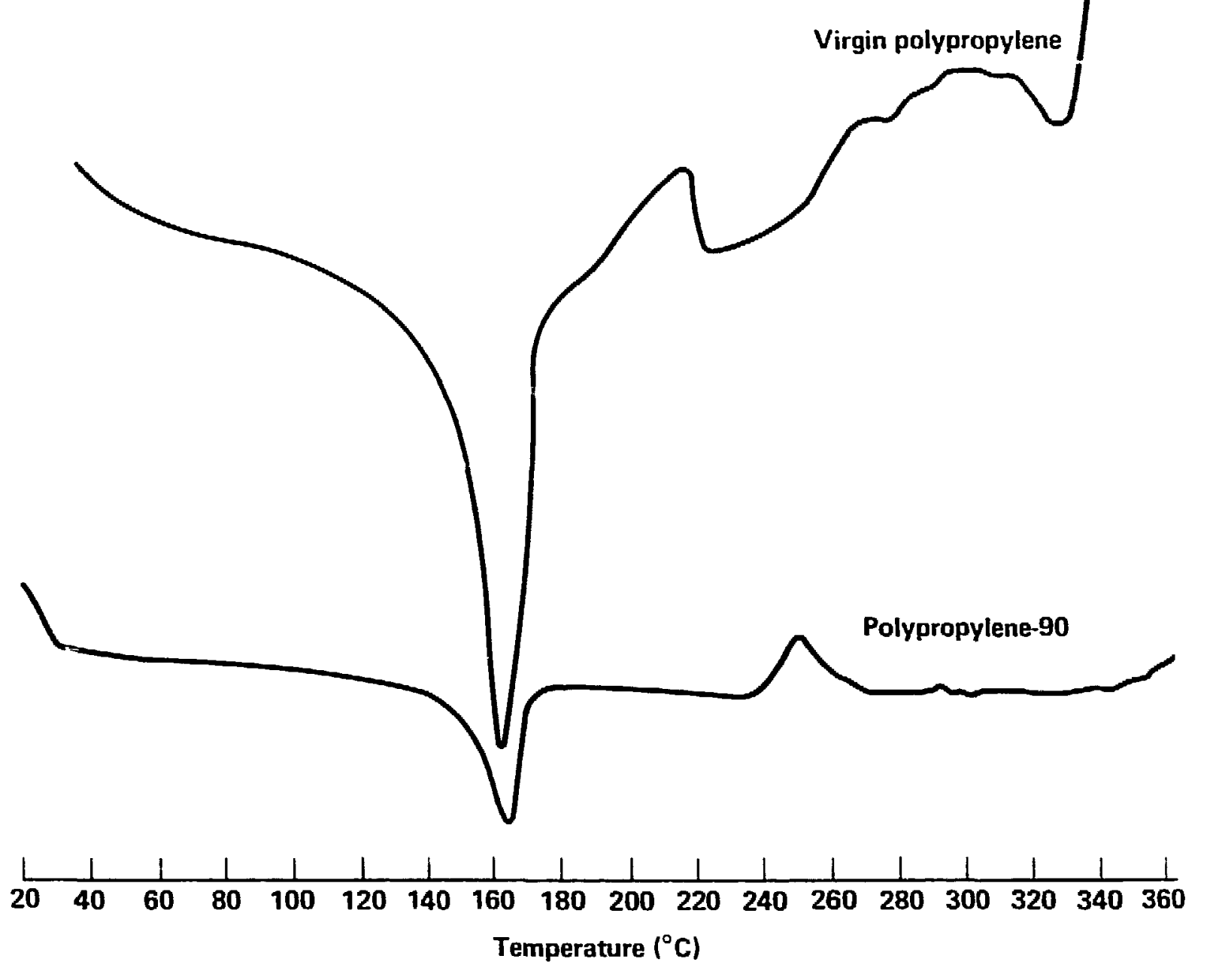

Figure 39. DSCA of virgin polypropylene and polypropylene-90 heated in air at $20^{\circ} \mathrm{C} / \mathrm{min}$. 


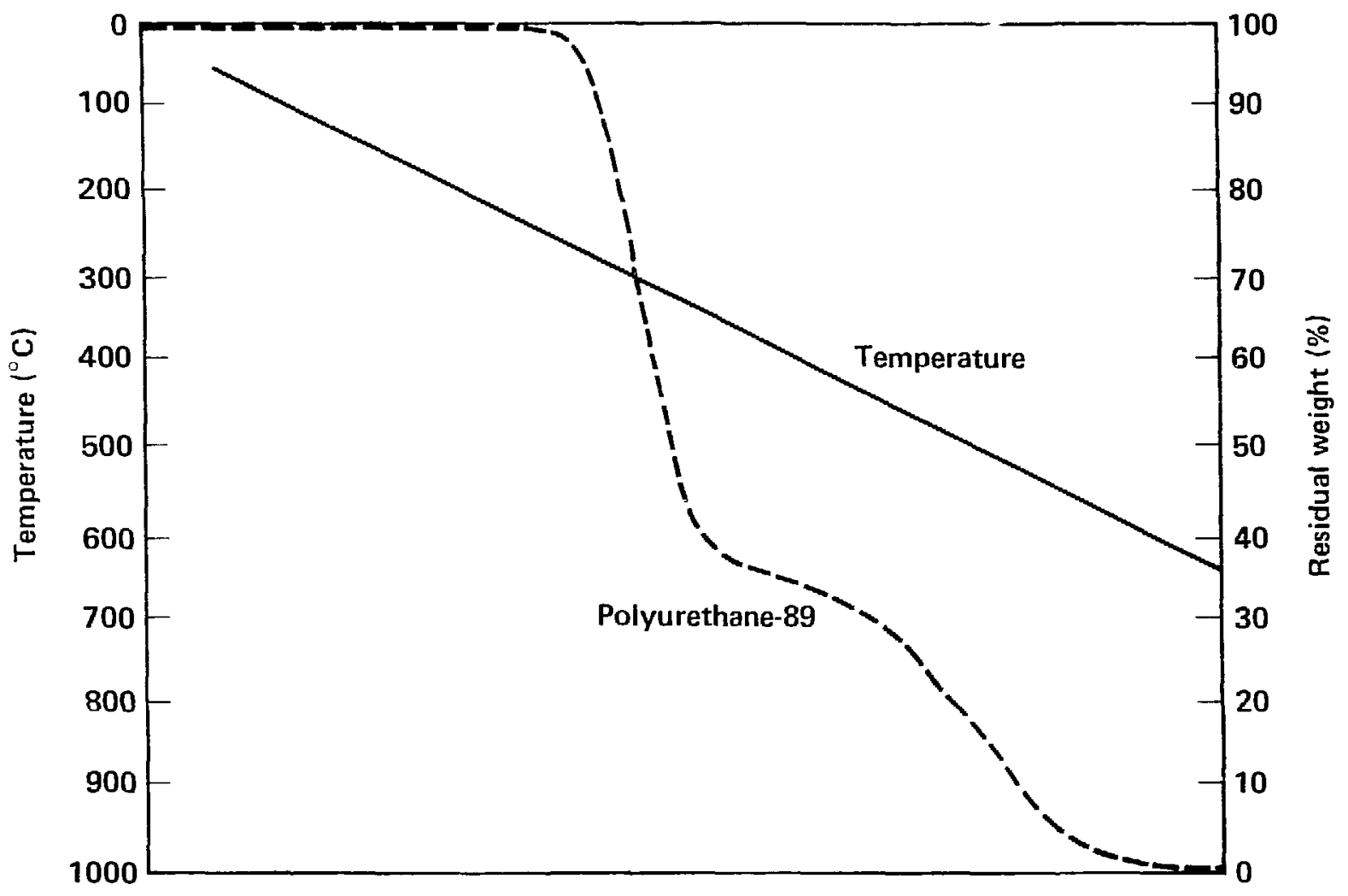

Figure 40 . Thermogram of polyurethane-89 heated in air at $20^{\circ} \mathrm{C} / \mathrm{min}$.

$217^{\circ} \mathrm{C}$, which we attribute to melting, and a slight exotherm at $337^{\circ} \mathrm{C}$, which we attribute to oxidation (Fig. 43). Some researchers believe that the insignificant weight loss at this phase of pyrolysis is due to random $\mathrm{C}-\mathrm{N}$ bond breaking to form oligomers without the subsequent formation of volatiles. ${ }^{12}$ At a temperature of about $380^{\circ} \mathrm{C}$, we noticed rapid weight loss accompanied by a series of exotherms due to degradation of the polymer itself as well as the various additives.

Higher heating rates, shown in Table 14, increased the temperature responsible for the onset of the first phase of weight loss but did not have a similar effect on the second or the main decomposition phase. As observed with other insulations, higher heating rates led to increased rates of degradation and decreased amounts of char. Thus, the char content decreases slowly up to the heating rate of $40^{\circ} \mathrm{C} / \mathrm{min}$ and becomes completely oxidized at a heating rate of $80^{\circ} \mathrm{C} / \mathrm{min}$. The gaseous pyrolyzates of this formulation are currently being analyzed. The liquid pyrolyzate generated in our thermogravimetric analyzer during the main phase of pyrolysis and analyzed via gaschromatographic, mass-spectrometric analysis on the Carbowax-20M fused-silica capillary column show caprolactam and its various degradation products, including 1-hexene, 1-methylimidazole, 2,3-dimethylpyramid-4-one and methyl-succinic acid [Appendix B (Fig. B16)].

\section{Mylar}

This material was designed for use in insulation of small signal wire.

TGA results of mylar-139 and virgin mylar in air showed three regions of weight loss (Fig. 44). There is a very g-adual weight loss region, a main degradation phase, and a char-oxidation region. For samples heated in air at $20^{\circ} \mathrm{C} / \mathrm{min}$ from ambient to $700^{\circ} \mathrm{C}$, the first phase of pyrolysis begins at $220^{\circ} \mathrm{C}$, the second phase at $390^{\circ} \mathrm{C}$, and the last phase at $510^{\circ} \mathrm{C}$, leaving no char at the end of 
Table 14. The effects of heating rates on the thermal degradation of polyurethane, nylon-3, mylar-139, and virgin polyethylene terephthalate.

\begin{tabular}{|c|c|c|c|c|c|c|c|}
\hline \multirow[b]{2}{*}{ Sample } & \multirow[b]{2}{*}{$\begin{array}{l}\text { Heating } \\
\text { rate } \\
\left({ }^{\circ} \mathrm{C} / \mathrm{min}\right)\end{array}$} & \multicolumn{2}{|c|}{ Main phase-1st phase } & \multicolumn{2}{|c|}{ 2nd phase } & \multirow{2}{*}{$\begin{array}{c}\text { Wt loss } \\
\text { in main } \\
\text { phase } \\
(\%)\end{array}$} & \multirow{2}{*}{$\begin{array}{c}\text { Char at en } \\
\text { of } \\
\text { pyrolysis } \\
\left(r_{i f)}\right.\end{array}$} \\
\hline & & $\begin{array}{l}\text { Onset of } \\
\text { wt loss } \\
\left({ }^{\circ} \mathrm{C}\right)\end{array}$ & $\begin{array}{c}\text { Degradation } \\
\text { rate } \\
(\% / \mathrm{min})\end{array}$ & $\begin{array}{c}\text { Onset of } \\
\text { wt luss } \\
\left({ }^{\circ} \mathrm{C}\right)\end{array}$ & $\begin{array}{c}\text { Degradation } \\
\text { rate } \\
(\% / \mathrm{min})\end{array}$ & & \\
\hline \multicolumn{8}{|c|}{ Polyurethane-89 } \\
\hline & 10 & 260 & 10.0 & 328 & 0.5 & 32 & $1.0^{2}$ \\
\hline & 20 & 271 & 23.0 & 332 & 1.7 & 49 & 1.0 \\
\hline & 40 & 264 & 44.0 & 330 & 1.8 & 53 & 1.8 \\
\hline & 80 & 270 & 80.0 & 350 & 4.0 & 63 & 1.0 \\
\hline & 160 & 250 & 76.5 & 390 & 10.0 & 70 & 1.0 \\
\hline
\end{tabular}

Nylon-3

$\begin{array}{rrrrrrr}10 & 120 & 0.1 & 392 & 14 & 56 & 13.0^{\mathrm{k}} \\ 20 & 120 & 0.3 & 425 & 24 & 46 & 12.5 \\ 40 & 135 & 0.3 & 400 & 46 & 61 & 9.0 \\ 80 & 150 & 0.5 & 400 & 68 / 30 \mathrm{~s}^{\mathrm{r}} & 85 & 0 \\ 160 & 160 & 0.5 & 420 & 87 / 30 \mathrm{~s}^{\mathrm{r}} & 86 & 0\end{array}$

Mylar-139

$\begin{array}{lllllll}10 & 381 & 14.0 & 463 & 3.5 & 30 & 0^{d} \\ 20 & 391 & 32.0 & 500 & 6.0 & 45 & 0 \\ 40 & 395 & 52.0 & 525 & 8.5 & 58 & 0 \\ 80 & 385 & 88.0 & 515 & 7.5 & 71 & 0\end{array}$

Virgin polyethylene terephthalate

\begin{tabular}{rcccccc}
10 & 390 & 20 & 492 & 2.5 & 46 & $0^{*}$ \\
20 & 365 & 17 & 486 & 6.0 & 67 & 2 \\
40 & 365 & 40 & 515 & 8.5 & 73 & 0 \\
80 & 410 & $81 / 30 \mathrm{~s}^{c}$ & 560 & 10.0 & 73 & 0 \\
160 & 510 & $69 / 24 \mathrm{~s}^{\mathrm{c}}$ & - & - & 71 & 0 \\
\hline
\end{tabular}

${ }^{a} \mathrm{pH}$ change in main phase that occurred at 10 and $20^{\circ} \mathrm{C} / \mathrm{min}$ was 7.21 and 6.63 , respectively.

${ }^{b} \mathrm{pH}$ change in main phase that occurred at 10 and $20^{\circ} \mathrm{C} / \mathrm{min}$ was 7.19 and 6.86 , respectively.

' Degradation rate took place in less than 1 minute (example: $68 \%$ in 30 seconds).

${ }^{d} \mathrm{pH}$ change in main phase that occurred at 10 and $20^{\circ} \mathrm{C} / \mathrm{min}$ was 7.20 and 6.97 , respectively.

e $\mathrm{pH}$ change in main phase that occurred at 10 and $20^{\circ} \mathrm{C} / \mathrm{min}$ was 7.27 and 6.68 , respectively.
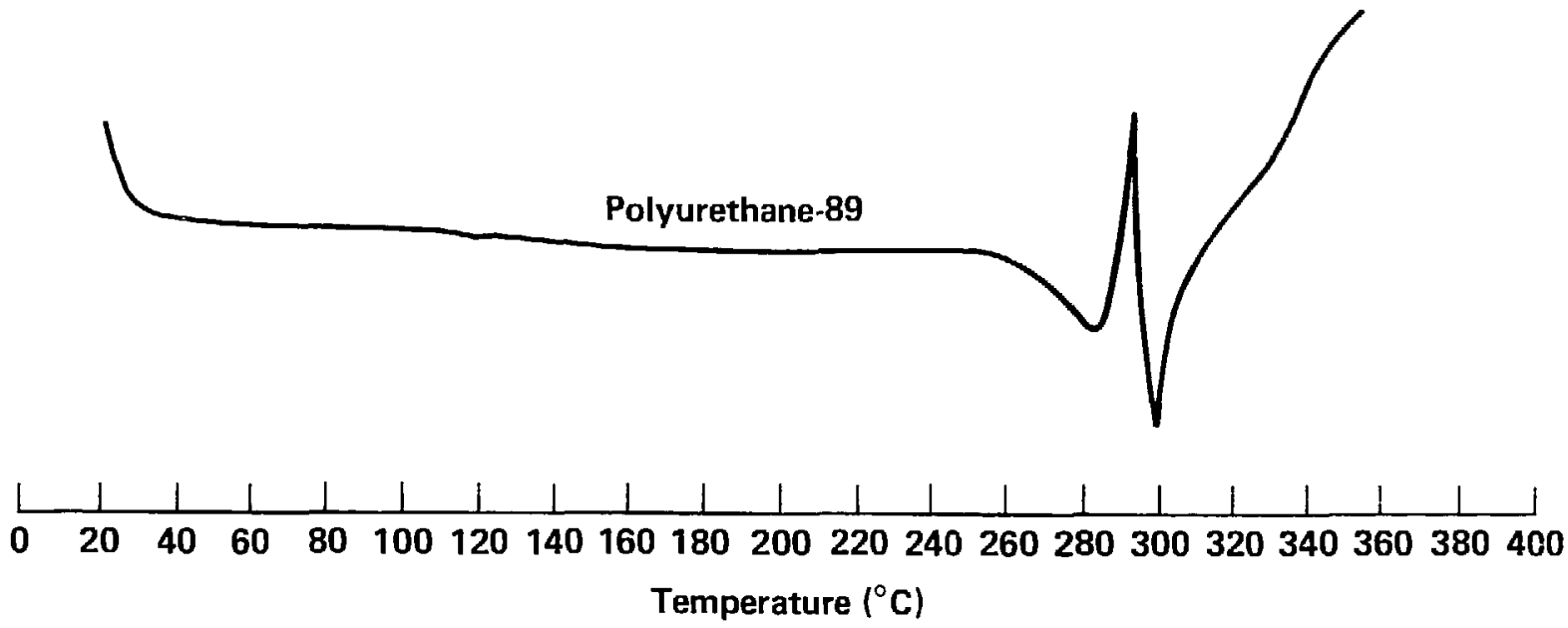

Figure 41. DSCA of polyurethane -89 heated in air at $20^{\circ} \mathrm{C} / \mathrm{min}$. 


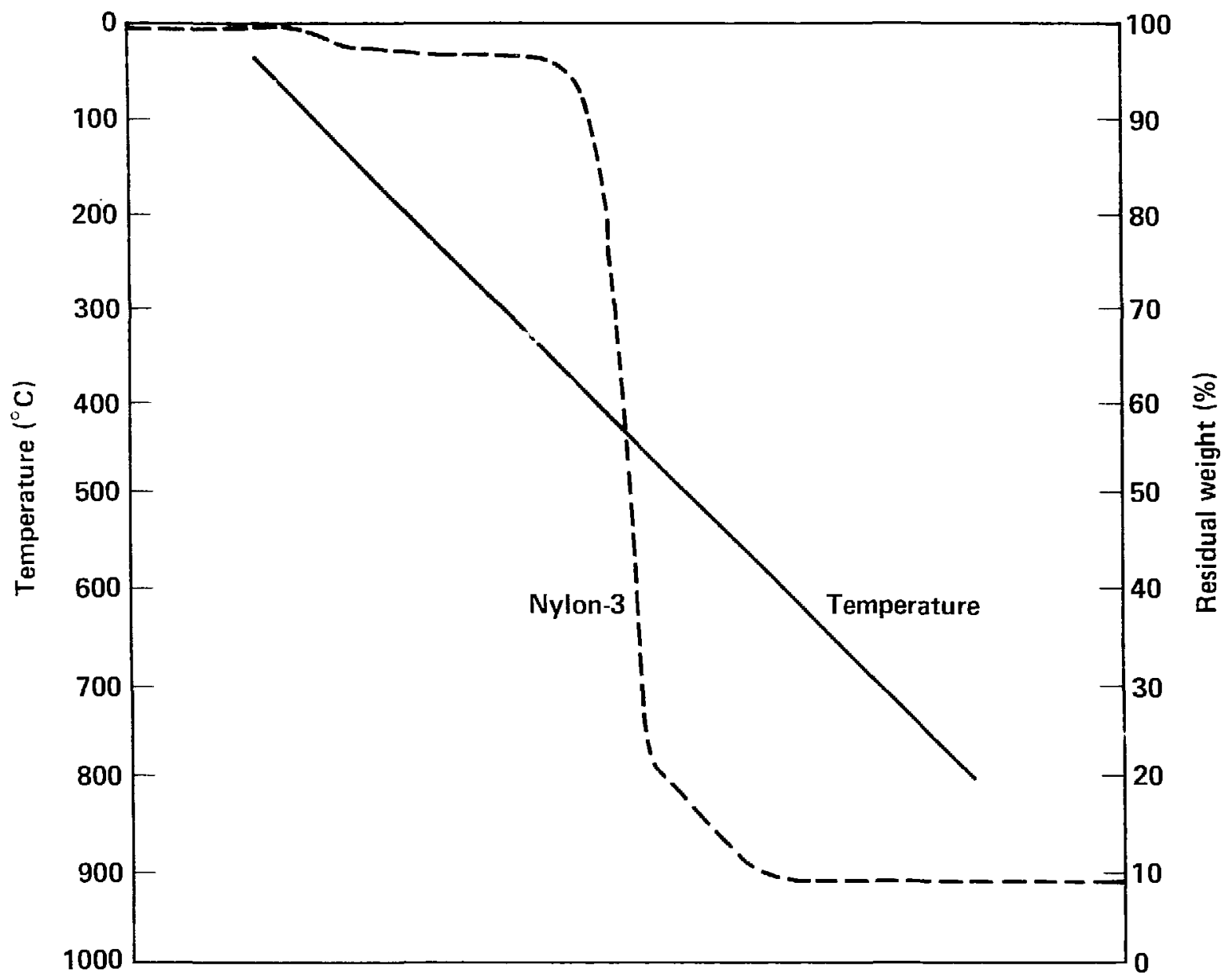

Figure 42. Thermogram of nylon-3 heated in air at $20^{\circ} \mathrm{C} / \mathrm{min}$.

pyrolysis. Our DSCA study in air showed two endotherms in the first phase (Fig. 45), one at $206^{\circ} \mathrm{C}$ (which we attribute to melting), and the other starting at $248^{\circ} \mathrm{C}$, which we attribute to random bond scission with very little ring or ester-group breakdown. The beginning of the main degradation phase is accompanied by an exotherm that begins at $340^{\circ} \mathrm{C}$ and is due to ring breakdown, destruction of the ester linkages, and formation of free radicals which recombine to form various aromatic and aliphatic degradation products.

Heating rates between 10 and $40^{\circ} \mathrm{C} / \mathrm{min}$ have no effect on the temperature responsible for initial weight loss (Table 14). However, a heating rate of $80^{\circ} \mathrm{C} /$ min lowers the temperature responsible for the initial weight loss from $220^{\circ} \mathrm{C}$ to $100^{\circ} \mathrm{C}$. The temperatures leading to initial degradation in the second and third phase of pyrolysis are slightly increased by the higher heating rates. The degradation rates increase substantially in the second phase of pyrolysis with higher heating rates, increase moderately in the third phase of pyrolysis, and remain the same in the initial phase of pyrolysis. There is no char at the end of all pyrolysis runs.

Gas-chromatographic analysis results of the liquid pyrolyzate generated during the second degradation phase and separated on our Carbowax-20M revealed predominantly aromatic compounds [Appendix B (Figs. B17 and B18)]. The gaseous pyrolyzate is presently being analyzed.

\section{Conclusions}

Our most practical finding is that all of the insulations we analyzed formed detectable 


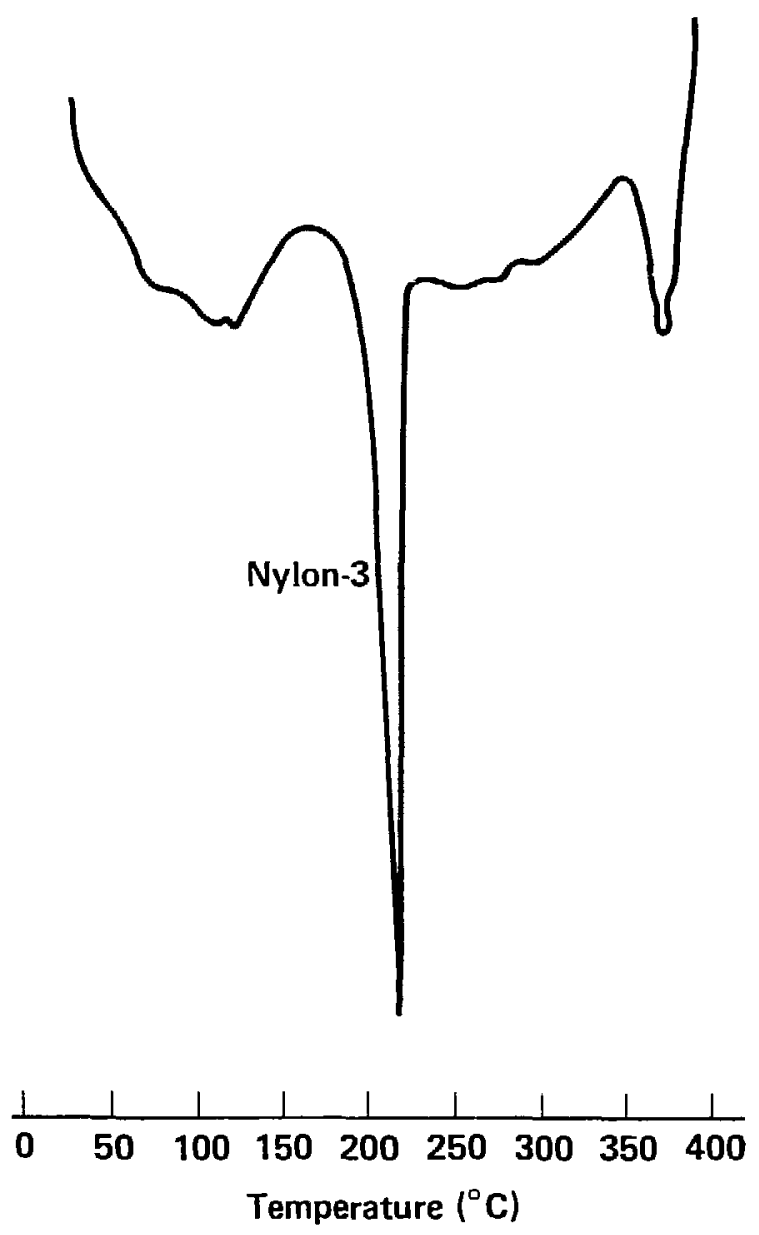

Figure 43. DSCA of nylon-3 heated in air at $20^{\circ} \mathrm{C} / \mathrm{min}$. amounts of light hydrocarbons upon smoldering or flaming combustion. These components could be detected in the very early degradation stage of the samples, either heated under controlled laboratory conditions or ignited in our large-scale test cell. Such information is useful for selecting or designing appropriate early warning alarm systems for buildings housing costly equipment.

Results of the gas-chromatographic, massspectrometric analysis of the liquid pyrolyzates ran be used to isolate those insulations that incorporate flammable plasticizers. The data, however, shows that there are no unique components pertinent to specific insulations that can be of practical value in fire detection.

As stated in our previous reports, the mode of thermal degradation of the insulations is influenced by the composition of the formulations of the insulations. Some plasticizers such as dioctylphthalates will enhance the flammability of the insulations, and, therefore, should be accompanied by flame retardants if used in the insulation.

Production of acidic components is enhanced by higher heating rates. However, higher heating rates do not increase the total acid production. The presence of acid acceptors (e.g., $\mathrm{ZnO}, \mathrm{MgO}$, $\mathrm{Sb}_{2} \mathrm{O}_{3}$ and $\mathrm{CaCO}_{3}$ ) will influence how much acid is released into the environment.

In general, flame retardants used in the insulations we studied increased charring and decreased the degradation rate during the main phase of pyrolysis. 


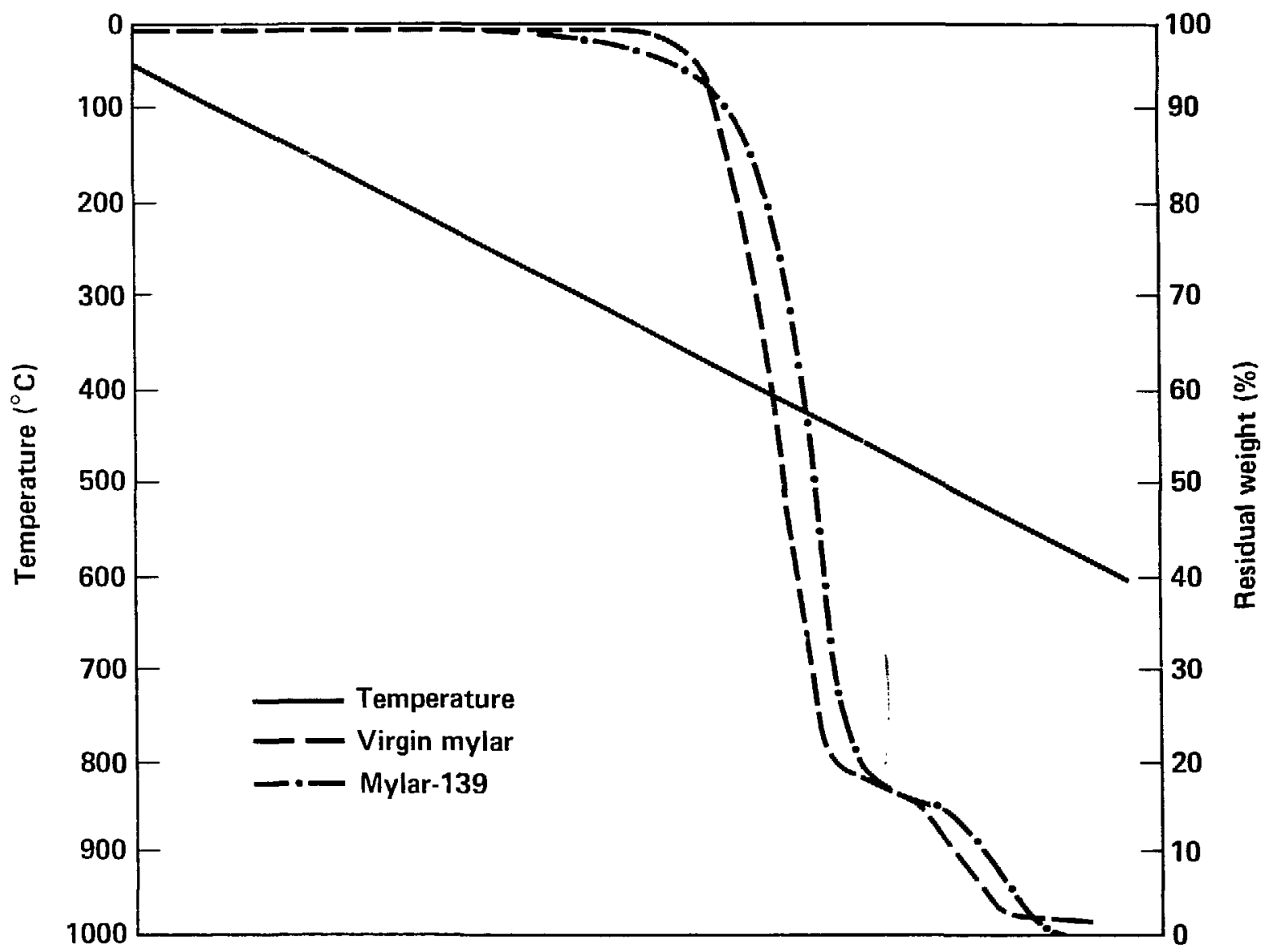

Figure 44. Thermogram of virgin mylar and mylar- 139 heated in air at $20^{\circ} \mathrm{C} / \mathrm{min}$. 


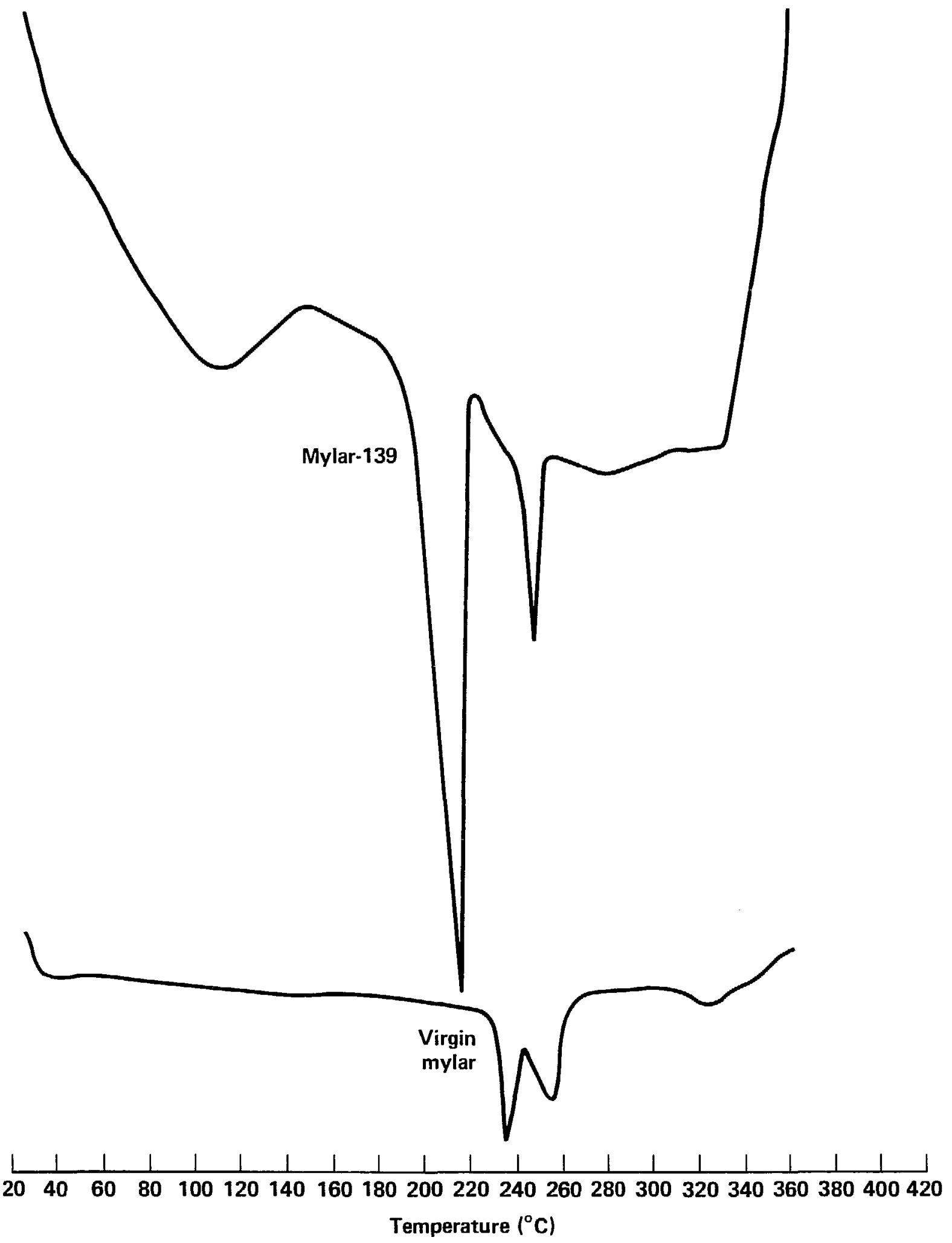

Figure 45. DSCA of virgin mylar and mylar-139 heated in air at $20^{\circ} \mathrm{C} / \mathrm{min}$. 


\section{Fire-Risk Assessment of the TMX-U Magnetic Fusion Experiment}

\section{Introduction}

Over the course of our studv, one major objective has been to develop a protocol to assess fire risk in DOE facilities. This protocol would ultimately integrate all of our experimental and analutical efforts to evaluate potential fire hazards, fire-protection system response, and potential fire damage to such facilities. Research facilities, unlike commerciai industrial settings, ${ }^{13,14}$ require slightly different rules for assessing fire risk. In research, funds are allocated to obtain information in a tımely manner as opposed to an industrial setting where fire-1isk assessments are made with regard to some uncertain impact on profit. In high technologv research facilities, we measure fire risk relative to the impact on program schedules and budgets in the form of milestone delays and budget increases tue to potential fire-related damage. In order to identify the specific nature of fire risk at these facilities, we choose to assess these risks relative to the research program at each facility on an individual experiment, on a Division or Department level, and ultimately at the DOE level.

As described in previous reports, we developed and used the protocol listed in Table 15 to provide a consistent basis for determining various levels of fire protection in DOE-research facilities. In summary, the assessment involves the following steps:

- Defining the potential hazard and magnitude of fire in each critical zone, area or compartment;

- Assessing the reliability and effectiveness of the fire-protection system; and

- Evaluating the interaction of the above two efforts in order to estimate the amount of damage (in terms of programmatic delay and capital loss) to eacr a area.

The Tandem Mirror Experiment-Upgrade (TMX-U) primarily addresses steps 2 and 4 in Table 15. The study is a semi-detailed survey of TMX-U operations covering critical equipment replacement costs, delivery and repai, times, operational necessity, and resultant estimated experimental down times.

The following data was provided by knowledgeable operations personnel and represents the best current information as to the potential negative impact on the TMX-U budget and schedule from fire-caused damage.

\section{Facility Description}

Figure 46 lists the objectives of the TMX-U experiment and the subsystems necessary to pursue these objectives. Additionally, Fig. 47 illustrates the physical location of these subsystems housed in Building 435. Figure 48 is a simplified representation of hardware and equipment essential to the operation of the experiment.

As indicated in Fig. 46, all subsystems need to be working for the facility to be fully operational. However, contingency workaround plans exist for some of these systems. Given the layout and elevation plans of the experiment building, we needed to identify and evaluate specific areas and compartments of the facility that would ha:e a significant impact on continued progress of the program. One basic assumption was that the experimental program depends only upon equipment availability.

The information summarized in Tables 16 through 18, which list each of the TMX-U subsystems and their primary components, was provided by programmatic personnel responsible for each subsy'stem. We assumed a loss of these components, and calculated the estimated time delays and associated replacement costs.

In addition, we have noted whether contingency workaround plans and/or spares exist for subsystems and components. The length of programmatic delay's must be compared to the experiment's critical path milestones, or CPM, to evaluate their negative impact on the research schedule. Similarly, the expected replacement costs must be weighed against yearly funding levels that might cause delays in additional equipment purchases.

In practice, personnel wculd develop and use these tables to identify potentially high consequence areas due to their exorbitantly high values and criticality to the continued operation of TMX-U. Once these "critical" areas are identified, a fire-growth model would be used to predict the fire threat and determine the mitigating effects of the fire-protection system. The analytical results describe the fire risk. If it turns out that resulting fire losses are unacceptable due to high operational value (i.e., approaching the larger figures in Tables 16-18), then program management must make the decision to either accept this fire risk or initiate changes to reduce it to an acceptable level. 
Table 15. General flow of systems approach to fire risk.

1

DIVIDE BLDG. INTO ZONES

\section{CRITERIA:}

A. May Use Fire Protection Zones.

B. Natural Building Boundaries (Walls and Rooms).

2

SELECT CRITICAL AREAS FOR ANALYSIS

\section{CRITERIA:}

A. Capital Loss.

B. Programmatic Delay.

\section{3 \\ PERFORM ANALYSES TO DETERMINE FIRE HAZARD AND ZONE}

CRITERIA:
A. Fire Growth Analysis.
B. Fire Protection System Analysis.
C. Research into Identifieu Problem Areas.

4 ASSESS POTENTIAL LOSS IN EACH CRITICAL ZONE

CRITERIA:

A. Programmatic Delay.

B. Capital Loss.

5

ASSESS EXPT. FIRE IMPACT ACCEPTABILITY AND COMPARE EACH ZONE

CRITERIA:

A. LLNL Guidelines.

B. DOE Guidelines.

C. Programmatic Delay.

6

IDENTIFY COST-EFFECTIVE SOLUTIONS TO INCREASE FIRE SAFETY OF FACILITY

CRITERIA:

A. Reiterate Loss Assessment With Recommended Changes. 


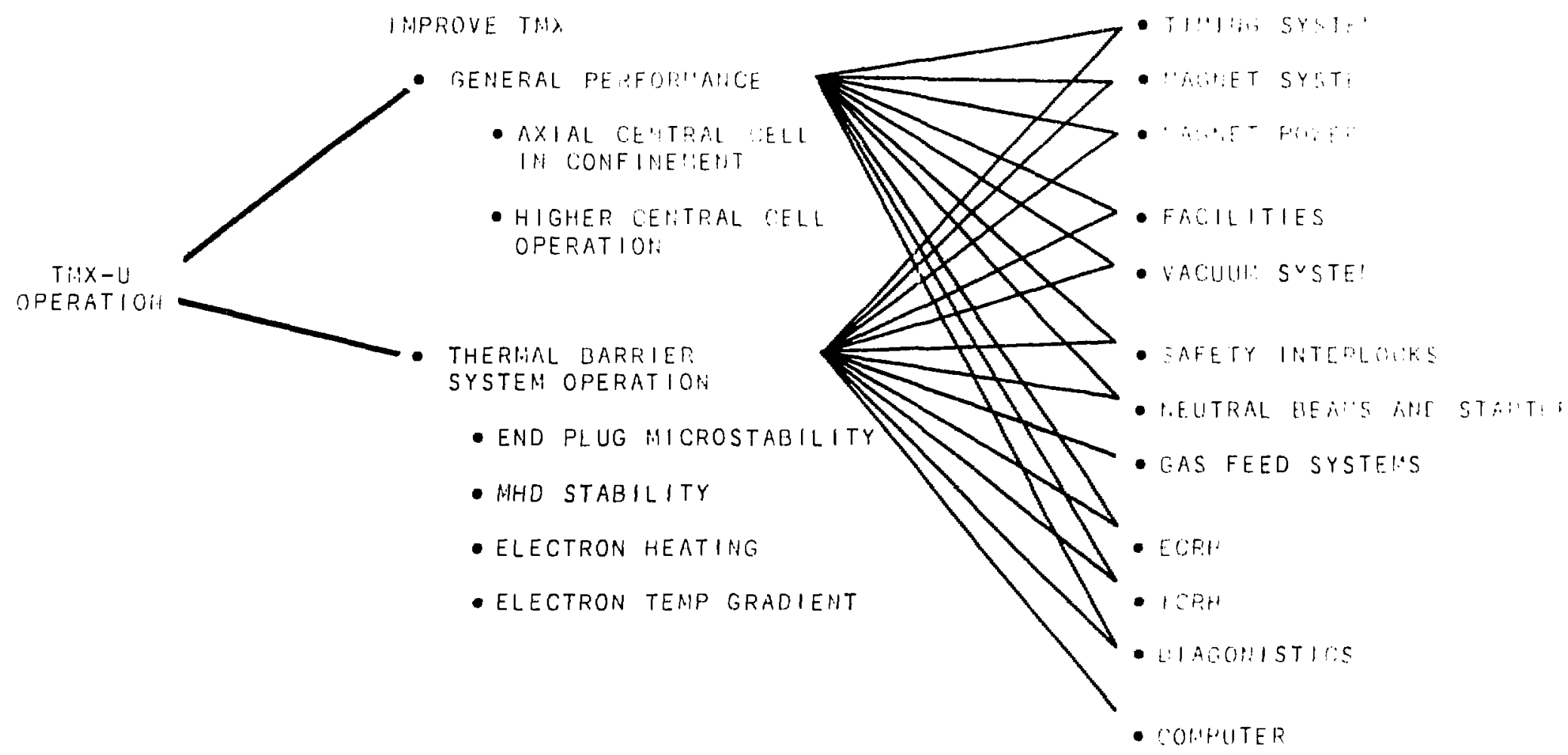

Figure 46. TMX-U objectives and critical subsystems. 


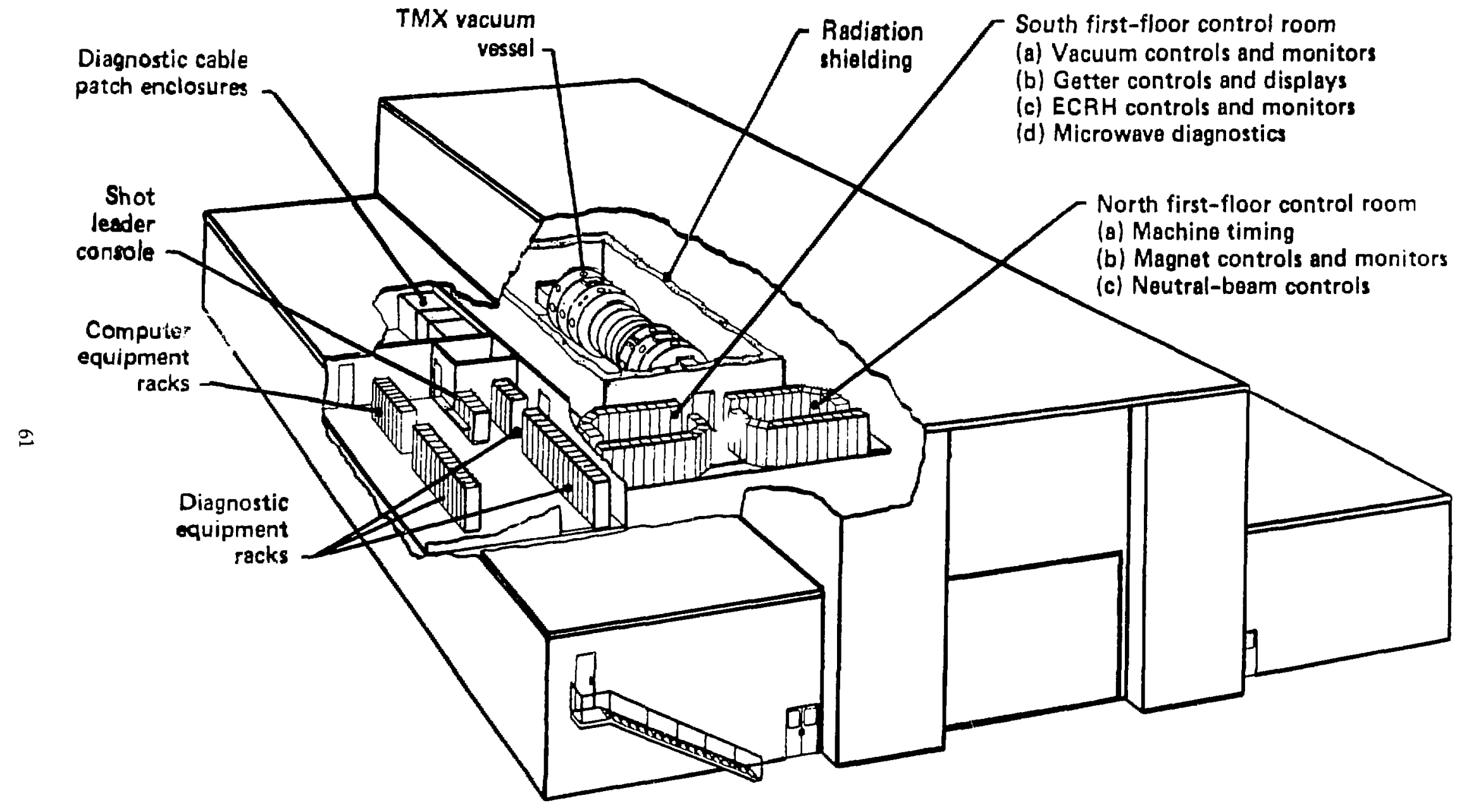

Figure 47. TMX-U experimental facility. 


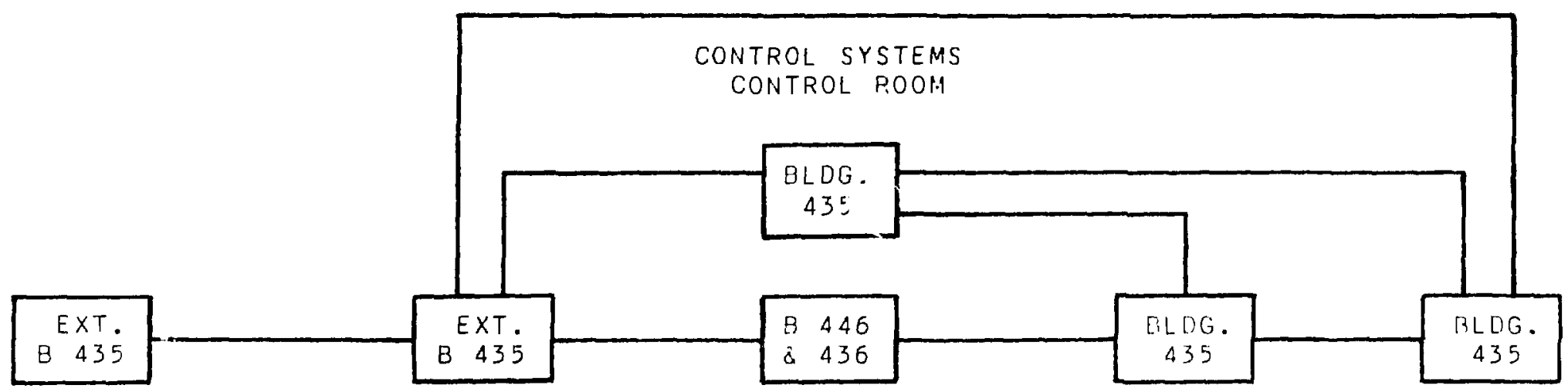

$P G$ \& $E$

POWEP

$=$

- POHER TRAIISFORMERS (SUESTATI ONS)

\section{POWER SOURCE CONDITIONING}

- magnet power

- neutral beam POWER

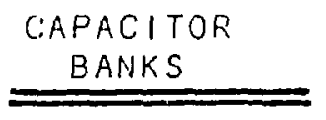

- magnet poller

- neutral beami POWER

\section{EXPERIIPENT BAY}

$=$

- maghets

- LCW \& OTHER FACILITIES

- ECRH
TPAX-U DEVICE

- olagmostics

- ICRH

- neutral beaki HARDWARE

- ECRH

- oIagnostics

Figure 48. Essential TMX-U subsystems. 
Table 16. Survey results of operational readiness for TMX-U (systems 1-4).

\begin{tabular}{|c|c|c|c|c|c|c|c|c|}
\hline \multicolumn{4}{|c|}{ Programmatic delay } & \multirow[b]{2}{*}{$\begin{array}{c}\text { Strategic bldg. } \\
\text { containing strategic } \\
\text { equipment }\end{array}$} & \multicolumn{4}{|c|}{ Replacement cost (19805) $10^{3}$} \\
\hline Least & Expected & Most & $\begin{array}{l}\text { Workaround } \\
\text { plan }(Y / N)\end{array}$ & & Least & Expected & Most & $\begin{array}{c}\text { Eqpt. spares } \\
\text { or immediate } \\
\text { delivery }(Y / N)\end{array}$ \\
\hline 8 wks & 12 wks & 16 wks & Yes & $\begin{array}{l}\text { 1) Supervisory timing } \\
\text { system } \\
\text { (HP 9835, camac, } \\
\text { buffers, wiring) }\end{array}$ & 10. & 50. & 60. & Yes \\
\hline $\begin{array}{l}7 \mathrm{mos} \\
3 \mathrm{mos}\end{array}$ & $\begin{array}{r}12 \text { mos } \\
9 \text { mos }\end{array}$ & $\begin{array}{l}18 \mathrm{mos} \\
12 \mathrm{mos}\end{array}$ & $\begin{array}{l}\text { No } \\
\therefore \therefore\end{array}$ & $\begin{array}{l}\text { 2) Magnet set subsystem } \\
\text { end plug (per set) } \\
\text { transition set } \\
\text { (ner set) }\end{array}$ & $\begin{array}{l}300 . \\
200 .\end{array}$ & $\begin{array}{r}1500 . \\
660 .\end{array}$ & $\begin{array}{r}1500 . \\
660 .\end{array}$ & $\begin{array}{l}\text { No } \\
\text { No }\end{array}$ \\
\hline $3 \mathrm{mos}$ & $6 \mathrm{mos}$ & $x$ mos & Yes & - central cell & 1.5 & 175. & 550. & coils exist \\
\hline $\begin{array}{l}- \\
- \\
- \\
- \\
-\end{array}$ & $\begin{array}{l}5 \mathrm{mos} \\
5.5 \mathrm{mos} \\
5.5 \mathrm{mos} \\
1.5 \mathrm{mos} \\
1.5 \mathrm{mos}\end{array}$ & $\begin{array}{l}- \\
- \\
- \\
- \\
-\end{array}$ & $\begin{array}{l}\text { No } \\
\text { No } \\
\text { No } \\
\text { No } \\
\text { No }\end{array}$ & $\begin{array}{l}\text { 3) Magnet power subsystems } \\
\text { - substation (ea.)(7) } \\
\text { pwr supply (ea.)(42) } \\
\text { - cables (ea. run)(10) } \\
\text { - controls (set)(1) } \\
\text { - computer (1) }\end{array}$ & $\begin{array}{l}- \\
- \\
- \\
- \\
-\end{array}$ & $\begin{array}{c}90 . \\
40 . \\
7 \\
10 . \\
10 .\end{array}$ & $\begin{array}{l}- \\
- \\
- \\
- \\
-\end{array}$ & $\begin{array}{l}\text { No } \\
\text { No } \\
\text { No } \\
\text { Yes } \\
\text { No }\end{array}$ \\
\hline $\begin{array}{l}2 \text { days } \\
- \\
+ \text { hrs }\end{array}$ & $\begin{array}{l}2 \text { days } \\
\text { Plant Engr. }\end{array}$ & 3 days & & $\begin{array}{l}\text { 4) Facilities } \\
\text { - vacuum valves } \\
\text { - cooling water lcw } \\
\text { - power }\end{array}$ & $\begin{array}{c}200 \\
- \\
200\end{array}$ & $\begin{array}{l}250 . \\
\text { Plant Engr. } \\
250 .\end{array}$ & $\begin{array}{l}300 . \\
300 .\end{array}$ & $\begin{array}{c}\text { No } \\
- \\
\text { Y/N (SIFTH }\end{array}$ \\
\hline
\end{tabular}

Table 17. Survey results of operational readiness (systems 5-9).

\begin{tabular}{|c|c|c|c|c|c|c|c|c|}
\hline \multicolumn{4}{|c|}{ Programmatic delay } & \multirow[b]{2}{*}{$\begin{array}{c}\text { Strategic bldg. } \\
\text { containing strategic } \\
\text { equipment }\end{array}$} & \multicolumn{4}{|c|}{ Replacement cost (1980S) $10^{\circ}$} \\
\hline Least & Expected & Most & $\begin{array}{l}\text { Workaround } \\
\text { plan }(Y / N)\end{array}$ & & Least & Expected & Most & $\begin{array}{c}\text { Eqpt. spares } \\
\text { or immediate } \\
\text { delivery }(\mathrm{M} / \mathrm{N})\end{array}$ \\
\hline $\begin{array}{l}1 \mathrm{mo} \\
1.25 \mathrm{mo} \\
2 \mathrm{mos}\end{array}$ & $\begin{array}{l}3 \mathrm{mos} \\
1.5 \mathrm{mos} \\
5 \mathrm{mos}\end{array}$ & $\begin{array}{l}6 \mathrm{mos} \\
2 \mathrm{mos} \\
8 \mathrm{mos}\end{array}$ & $\begin{array}{l}\text { Yes } \\
\text { No } \\
\text { No }\end{array}$ & $\begin{array}{l}\text { 5) Vacuum Vessel Subsystem } \\
\text { exter. vac. sys. } \\
\text { - vacuum vessel } \\
\text { getter system \& } \\
\text { pwr supplies }\end{array}$ & $\begin{array}{r}20 . \\
5 . \\
55 .\end{array}$ & $\begin{array}{r}35 . \\
7 . \\
90 .\end{array}$ & $\begin{array}{r}60 . \\
10 . \\
170 .\end{array}$ & $\begin{array}{l}\text { Partial spares } \\
\text { No } \\
\text { No }\end{array}$ \\
\hline 1 wk & 3 wks & $5 \operatorname{mos}$ & No & 6) Interlocks (etrl room) & 20. & 30. & 55. & Yes \\
\hline $\begin{array}{l}3 \mathrm{mos} \\
2 \mathrm{mos} \\
5 \mathrm{mos} \\
4 \mathrm{mos} \\
2 \mathrm{mos}\end{array}$ & $\begin{array}{l}5 \mathrm{mos} \\
4 \mathrm{mos} \\
7.5 \mathrm{mos} \\
5 \mathrm{mos} \\
3 \mathrm{mos}\end{array}$ & $\begin{array}{r}7 \text { mos } \\
6 \text { mos } \\
10 \text { mos } \\
6 \text { mos } \\
4 \text { mos }\end{array}$ & $\begin{array}{l}\text { No } \\
\text { No } \\
\text { No } \\
\text { No } \\
\text { No }\end{array}$ & $\begin{array}{l}\text { 7) Neutral beam system } \\
\text { - accel/decc area } \\
\text { arc. \& fil. area } \\
\text { - capacitor bank } 436 \\
\text { - 1st floor } 446 \\
\text { - control room area }\end{array}$ & $\begin{array}{l}360 . \\
246 . \\
560 . \\
160 . \\
200 .\end{array}$ & $\begin{array}{l}480 . \\
288 . \\
752 . \\
416 . \\
448 .\end{array}$ & $\begin{array}{l}540 . \\
378 . \\
960 . \\
520 . \\
480 .\end{array}$ & $\begin{array}{l}\text { No } \\
\text { No } \\
\text { No } \\
\text { No } \\
\text { No }\end{array}$ \\
\hline $\begin{array}{l}1 \text { mo } \\
- \\
-\end{array}$ & $\begin{array}{l}1.5 \text { mos } \\
1 \mathrm{mo} \\
1 \mathrm{mo}\end{array}$ & $\begin{array}{l}2 \operatorname{mos} \\
- \\
-\end{array}$ & $\begin{array}{l}\text { No } \\
\text { No }\end{array}$ & $\begin{array}{l}\text { 8) Gas feed system } \\
\text { - gas box } \\
\text { - puffer valves } \\
\text { - streaming guns }\end{array}$ & $\begin{array}{l}10 . \\
- \\
-\end{array}$ & $\begin{array}{r}16 . \\
5 . \\
10 .\end{array}$ & $\begin{array}{l}36 . \\
- \\
-\end{array}$ & $\begin{array}{l}\text { No } \\
\text { No } \\
\text { No }\end{array}$ \\
\hline negligible & 12 mos & $7.5 \mathrm{mos}$ & Yes & $\begin{array}{l}\text { 9) ECRH (electro/cyclotr } \\
\text { reson. heat) } \\
\text { - substation } \\
\text { - ac distribution } \\
\text { gyrotrons } \\
\text { wave guides (vessel } \\
\text { ext.) } \\
\text { - vessel internals } \\
\text { - A/C distrib. sub- } \\
\text { systems }\end{array}$ & 125. & 550. & 250. & partial spares \\
\hline
\end{tabular}


Table 18. Survey results of operational readiness (systems 10-12).

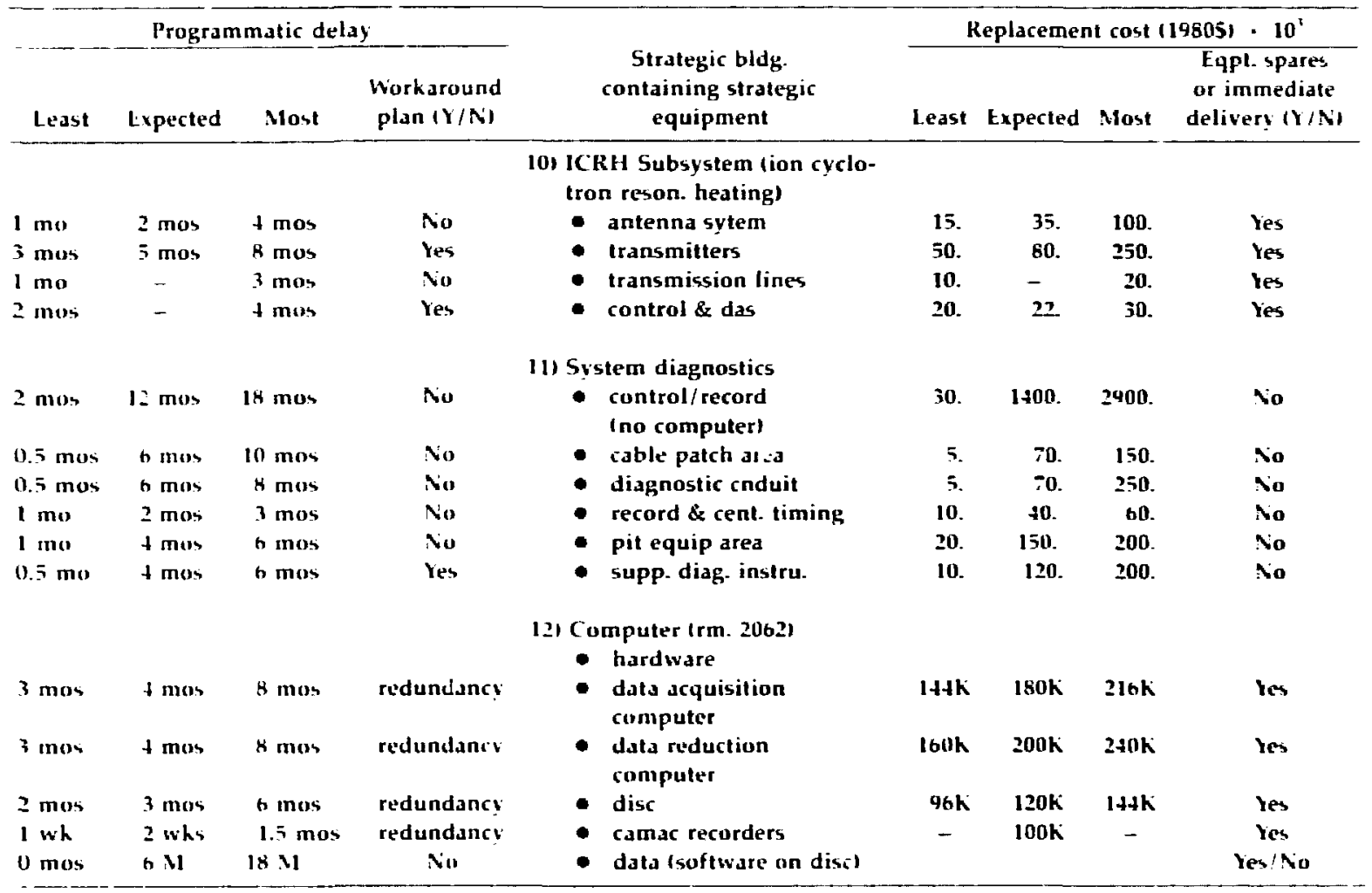

In FY 83, we will perform a complete fire-risk analisis on T:UX- $L$ that will include the predicted fire threat in critical areas, the fire-protection svstem response, and resultant damage. It will be the first validation exercise for the overall riskassessment methodology.

\section{Observations}

The potential loss assessment of the TMX-U fusion experiment produced these observations (Tables 16-18).

- Extensive fire damage to the following subsystems could cause prolonged time delays and exorbitant replacement costs: system diagnostics-control/recording (secor:d level of Building 435); magnet set subsystem-end plugs (central pit, Building 435); neutral beam subsystem (Building 436, Building 446, and control area).
- The primary high value areas are the vessel and control rooms in Bldg 435 .

- There is a notable lack of backup components and workaround plans in Building 435 vessel and control rooms.

- Basically, all subsystems are required to pursue both objectives of thermal harrier operation and $T M X$ general-performance improvement.

- More than $50 \%$ of expected schedule delay from potential fire damage for all critical subsystems is greater than four months.

The above observations are hased imlu on an extensive damage scenario, which should not be confused with the actual fire risk in these areas. As stated earlier. the fire risk cannot be determined without assessing potential damaze by predicting the fire threat and the degree of mitigation provided by the fire protection sistem response. The resultant damage may be minimal. marginal, or very severe and it is this level of risk that management must evaluate. 


\section{Conclusions and Future Work}

In FY 82 we have continued the validation of our experimental and analytical techniques specified in Fig. 1. Furthermore, we have been orienting our results towar: applic $t^{\text {tion }}$ in preparation for our target completion date in 1985. Our Fy 82 conclusions are summarized below:

\section{Large-Scale Vertical Cable Burns}

The performance of six large-scale rable burns in FY 82 provided preliminary validation of the test apparatus. Results of the experiments indicated that:

- It is difficult to achieve a sustained ignition with a $20 \mathrm{~kW}$ ignition source;

- After ignition, rate of flamespread is very slow;

- Rates of heat release were low and slow to peak:

- The low heat-release rates appeared to be due to the cable diameter $(1.25 \mathrm{~cm}$ to $2.54 \mathrm{~cm})$, the large percentage of conductor, and the packing densitv.

In FY 83 we will continue to use the protocol we developed in 1982 to confirm these observations. And, in the future, we will be evaluating the effect of varying ignition source strength, airflow: cable composition (i.e., multiconductor is solid copper, etc.), and cable diameter.

\section{Small-Scale Ease-of-Ignition Experiments}

The most important finding from this series of experiments was the development of a testing protocol to evaluate the effects of physical and chemical cable properties on susceptibility to ignition. This protocol will be used in FY 83 in an attempt to develop a means to predict a cable's time to ignition withnut having to perform a tes: on it.

\section{Fire Modeling}

The problems which surfaced in the 1981 series were rectified in the 1982 model burns. Furthermore, a number of modifications and improvements to the experimental setup and parameters were implemented. Data contained in rable 10 are semi-equilibrium values. These data will be used to rate preliminary models and e-tablish criteria for 193 tests. In faci, we wili use the same fuels in 1983 tests as we did in F) 82 tosts but we will vary the following parameters: tire location in test cell, ventilation infut and ouipu! lo cations (high, low; low; high, etc), and lecation of fire on the floor and above the flowr. These experiments will add to our growing data base of tire model validation data.

\section{Fire Chemistry}

This year's experiments emploved highor heating rates and produced the usetul DSCA and TGA results listed below:

- Laboratory results of thermal and chemr cal analysis can be used effectively to inter how a material will react in a real fire environment.

- Fasier htasing rates used in thermal gravi metric studies correspond to conditions found $m$ a real fire environment (large-siale experiments).

- The mode of thermal degradation of the insulations is influenced by the composition of the formulations of the plastic insulations

- Production of acidic components is en hanced by higher heating rates. However. higher heating rates do rot increase the total acid production.

- The presence of acid acceptor (c. $\mathrm{CaCO}_{3}$ ) influences how much aciù is released into the environment.

- Flame retardants used in the insulations studied increased charring and decreased the rate of degradation in the main phase of pyrolysis and therefore the rate of production of $\mathrm{HCl}$.

- Ail insulations studied form detectable amounts of light hydrocarbons in the early stages of degradation, both in lahoratory-scale and largescale burns. These light hyurocarbons couid possibly serve as signatures for early warning detection srsiems.

\section{Fire-Risk Analysis}

We continued to develop the components necessary to an overall tire-risk assesinient technique during FY 82 . Analysis of the LLNL TMX-L experiment produced the most detailed programmatic and budgetary information to date. The firemodeling effort is at a point where we should be able to afply it to the TMX-L critical spaces in $\mathrm{F}$ 
83. Furthermore, the reliability of fire-protection unteme can be eanily calculated from our previously completed studies. The interaction of these majer components, along with an assumed level of firs-protection effectiveness, will produce a predictid tevel of damage. Evaluation of resulting losis from ri. will yield fire risk in these spaces.

\section{References}

1. H. K. Hasegawa, N. J. Alvares, A. E. Lipska, H. W. Ford, and D. G. Beason, Fire Protectum Researeh for

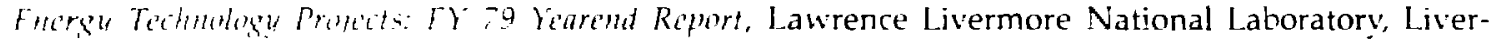
mote. California, L'CID-18902 (1981).

2. H. K. Hastegawa, V. J. Alvares, A. E. Lipska, H. W. Ford, S. Priante, and D. G. Beason, Fire Protection

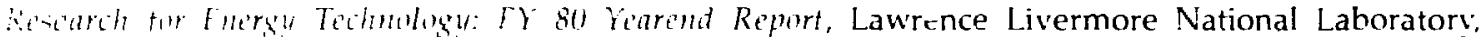
l.ivermore, California, LCRL-53179 (1981).

3. H. K. Hastegawa, N. I. Alvares, A. E. Lipska-Quinn, D. G. Beason, K. L. Foote, and S. J. Priante, Fir' Protection Re'sarch for Energy Technology: FY 81 Giarind Report, Lawrence Livermore National Laboratorv. Livermore, California, UCRI-53179-81 (1982).

4. E. E. Zukoski, K. Kubota, and B. Cetegen, Entramment in Fire Plumes, U.S. Dept. of Commerce, $\therefore$ ational Bureau of Standards, Washington, D.C., NBS-GCR80-294 (1980).

5. IEFK Standard fur Tupe Te'st of Class IE Electric Cables. Ficld Splices, and Commectums fur Nuclear Poarer Cincratme Statwm, the Institute of Electrical and Electronics Engineers, New York, New York, 1974

6. L. Orloff, Simplifict Radiation Mudeling of Pool Fires, Factory Mutual Research, Norwood, Mass., FMRC J.I. No. OE1EO.BU-1 (1980).

7. N. Alvares and K. Foote, Contrast Beture'n Natural and Experimentally Controlled Fires in Foricd Vontilafirh Fnthstris, Lawrence Livermore National Lahoratory, Livermore, CA, UCRL-88588 (1983).

8. H. Steckler, National Bureau of Standards, Gaithersburg, Maryland, private communication (1982).

9. C. F. Cullis and M. M. Hirschler, The Combustion of Organic Polymers, International Series of Monographs on Chemistry, Clarendon Press, Oxford, p. 129 (1981).

10. A. Holmstrom and E. M. Sorvik, "Thermal Degradation of Polvethylene in a Nitrogen Atmosphere of Low Oxygen Content 111 Structural Changes Occurring in Low Density of Polyethylene at Oxygen Contents Below 1.2\%," lournal of Applied Polymer Scicnce 18, 779 (1974).

11. K. Ashida, F. Yomauchi, M. Katoh, and T. Harada, Adtanced Lrethane Seience Technology 3, 130 (1974).

12. H. E. Stepniozka, industrial Engine

13. G. Ramachandran, "Statistical Methods in Risk Evaluation," International Symposium on Fire Risk Evaluation (1979), ISB.V 91-7144-138-7.

14. C. L. Farmer, "A Probabilistic Risk Analysis Technique With Applications to Enclosure Fires," International Symposium on Fire Risk Evaluation (1979), ISBN 91-7144-138-7. 


\section{Appendix A. \\ Mass-Balancing Equations}

$$
\begin{aligned}
& \int \text { Mass }_{\text {in }}=\frac{1.176 * 300 * 742}{\left(\text { Temp }_{\text {in }}+273\right) 760} \text { Inlet Air } 1.03 \\
& \text { Mass }_{\text {uut }}=-\frac{1.176^{*}(300)^{*} 742}{\left(\text { Temp }_{\mathrm{uu}}^{\mathrm{a}}+273\right) 760} 43 \sqrt{\frac{\text { diff pressure } \mathrm{Pa}}{\text { density exit air }}}
\end{aligned}
$$

${ }^{\mathrm{a}}$ Time delayed.

${ }^{\mathrm{b}}$ Values change with fuel type. 


\section{Appendix B. \\ Fire Chemistry Experiment Data}

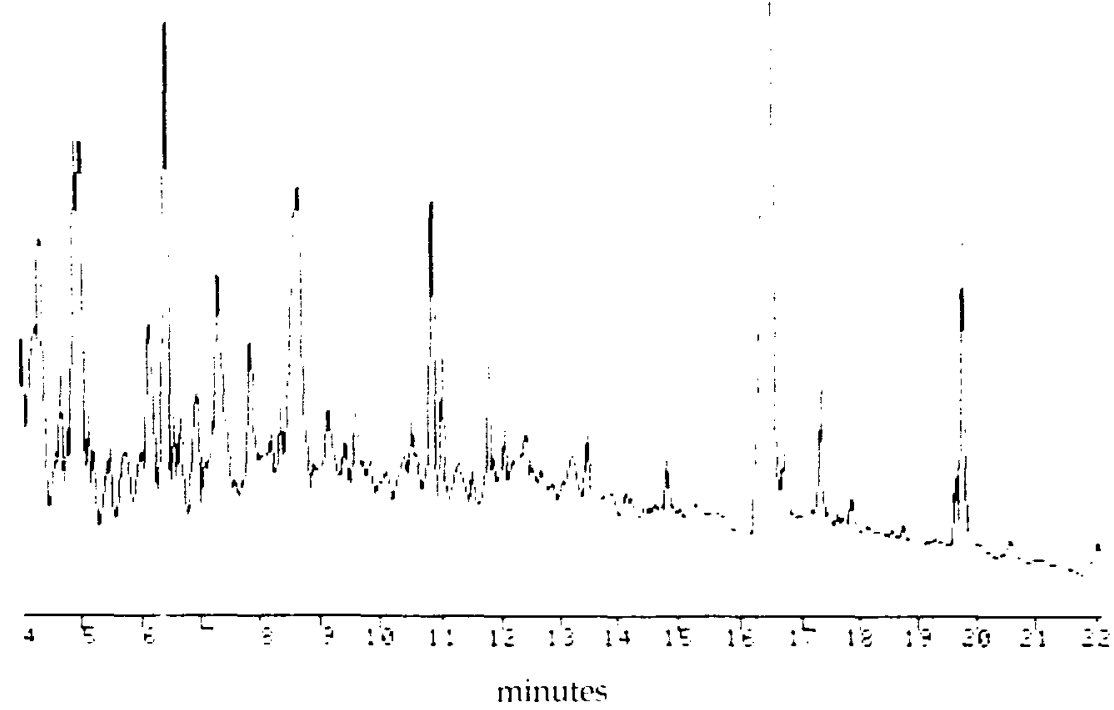

\begin{tabular}{rl}
\hline$\Upsilon_{k}$ & COMPOUND \\
\hline 4.2 & $\begin{array}{l}\text { 6-methyl-T-heptanol cis-3-hexene } \\
\text { 3-3 }\end{array}$ \\
4.4 & 1,2-dichloro-2-methylpropane \\
4.6 & 2,5 -dimethyl-trans-3-hexane \\
4.7 & 2-methyl-1-pentadecene \\
5.0 & 2,3-dimethylhexane, 2-phenylheptadecane \\
5.5 & T-chloro-heptadec-6-ene \\
5.7 & 3.7-dimethyl-1-octanol \\
6.1 & thujyl alcohol \\
6.7 & 1,1-dichloroacetone \\
7.0 & octyl acetate \\
7.9 & isooctyl alcohol \\
8.7 & 2-dimethylaminocyclohexanone \\
9.2 & hexacosanol-1 \\
9.6 & octadecanol-1 \\
10.9 & undecylenaldehyde \\
11.0 & citronylproprionate \\
16.5 & phthalic anhydride \\
17.4 & benzoic acid \\
17.8 & benzidine \\
19.6 & phenanthrene \\
19.8 & n-butylphthalate
\end{tabular}

Figure B1. Pyrolyzate of PVC-3 generated in air in tube pyrolyzer during the main region of degradation. Separation was performed on Carbowax-20M fused silica capillary column. 


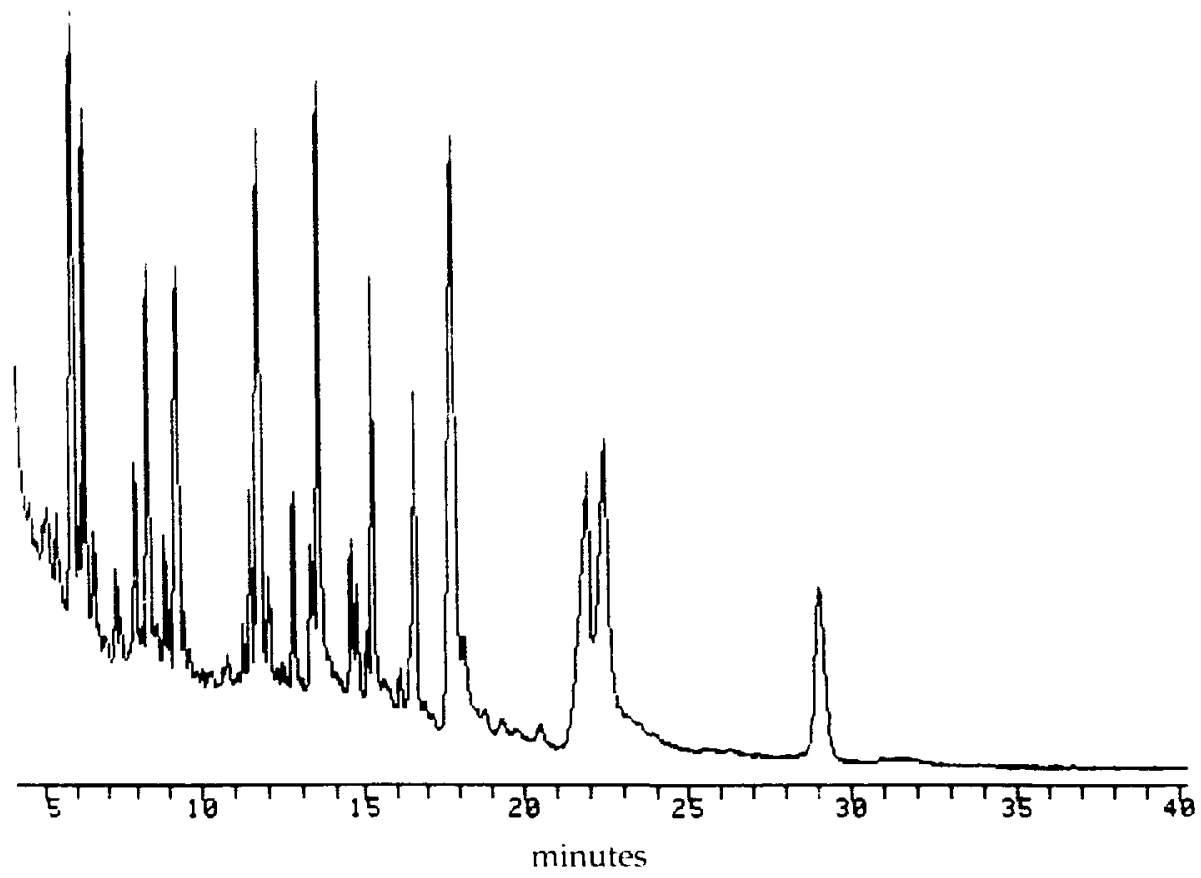

\begin{tabular}{ll}
\hline$T_{\mathrm{k}}$ & COMPOUND \\
\hline 5.1 & 2-ethyl-N-methyl pyrolidine \\
\hline 3.4 & 2-acetophenone \\
6.0 & 3-cholorodecane \\
6.3 & naphthalene \\
7.3 & methyl laurate \\
8.4 & 2,6 -ditertiary butvi-p-cresol \\
8.4 & biphenyl \\
9.3 & 2,6-di-T-butyl-1,4-benzoquinone \\
11.4 & methyl hexadecanoate \\
12.0 & fluorene \\
12.7 & 1-hexacosene \\
13.3 & methylstearate \\
13.6 & lauric acid \\
14.5 & n-octadecanitrile \\
15.1 & anthracene or phenanthrene \\
15.3 & myristic acid \\
16.3 & decanoic acid \\
17.8 & palmitic acid \\
21.9 & stearic acid \\
22.2 & dioctylphthalate \\
29.0 & 3,3,4,4-tetramethyl-2,2-diphenoxyethane
\end{tabular}

Figure B3. Pyrolyzate of PVC-104 generated in air in tube pyrolyzer during the main region of degradation separated on Carbowax-20M. 


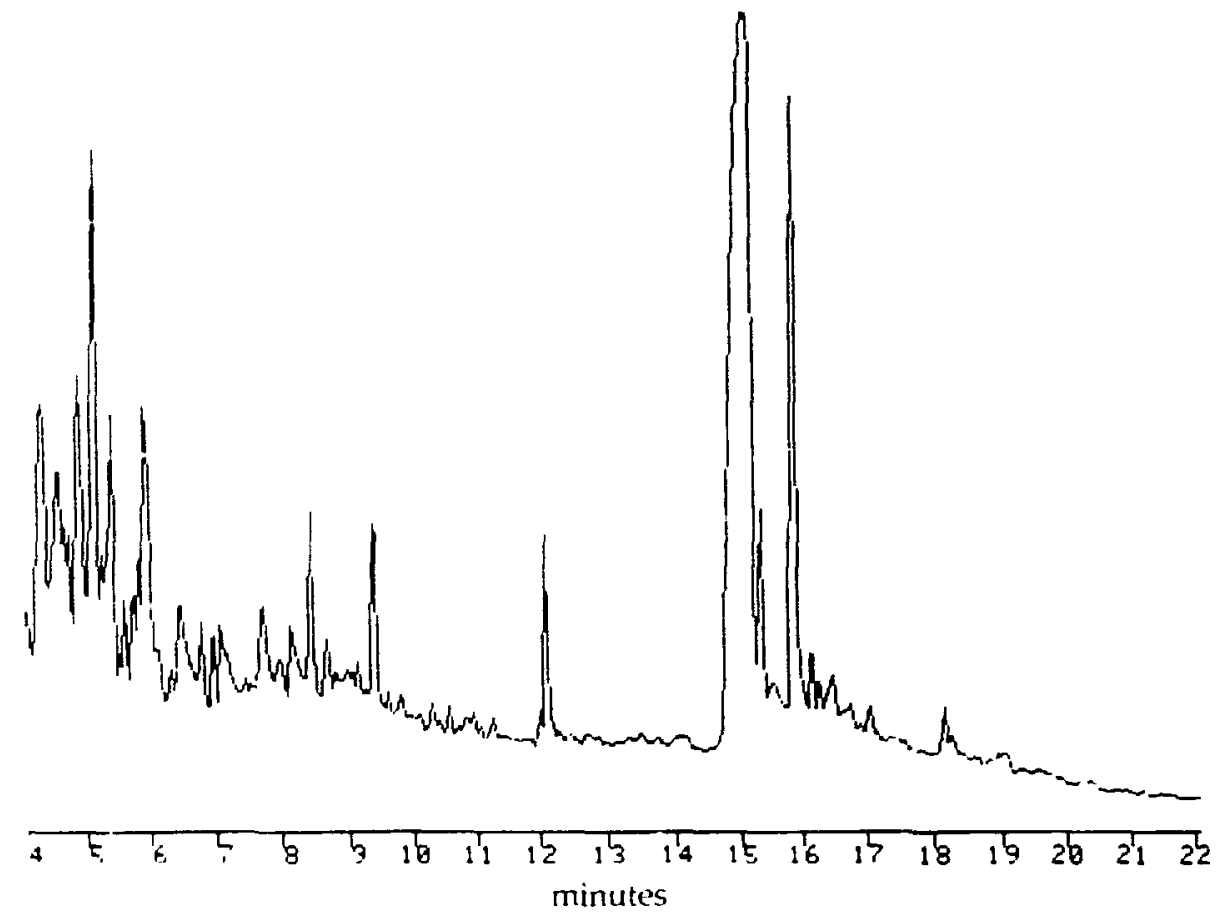

\begin{aligned} \multicolumn{1}{c}{$\mathrm{T}_{\mathrm{k}}$} & COMPOUND \\ \hline 4.3 & 0-isobutylhydroxylamine \\ 4.5 & 1-decanol \\ 4.9 & 1-chlorotetradecane \\ 5.1 & hexyl vinyl ether \\ $\mathbf{5 . 4} &$ n-heptane \\ 5.6 & unidentified \\ $\mathbf{8 . 1} &$ n-decyl ether \\ 9.4 & naphthalene \\ 12.1 & phenol \\ 15.1 & phthalic anhydride \\ 15.9 & benzoic anhydride \\ 18.1 & phthalic acid \\ 18.2 & phenanthrene \end{aligned}

Figure B2. Pyrolyzate of PVC-78 generated in air in tube pyrolyzer during the main region of degradation separated on Carbowax-20M. 


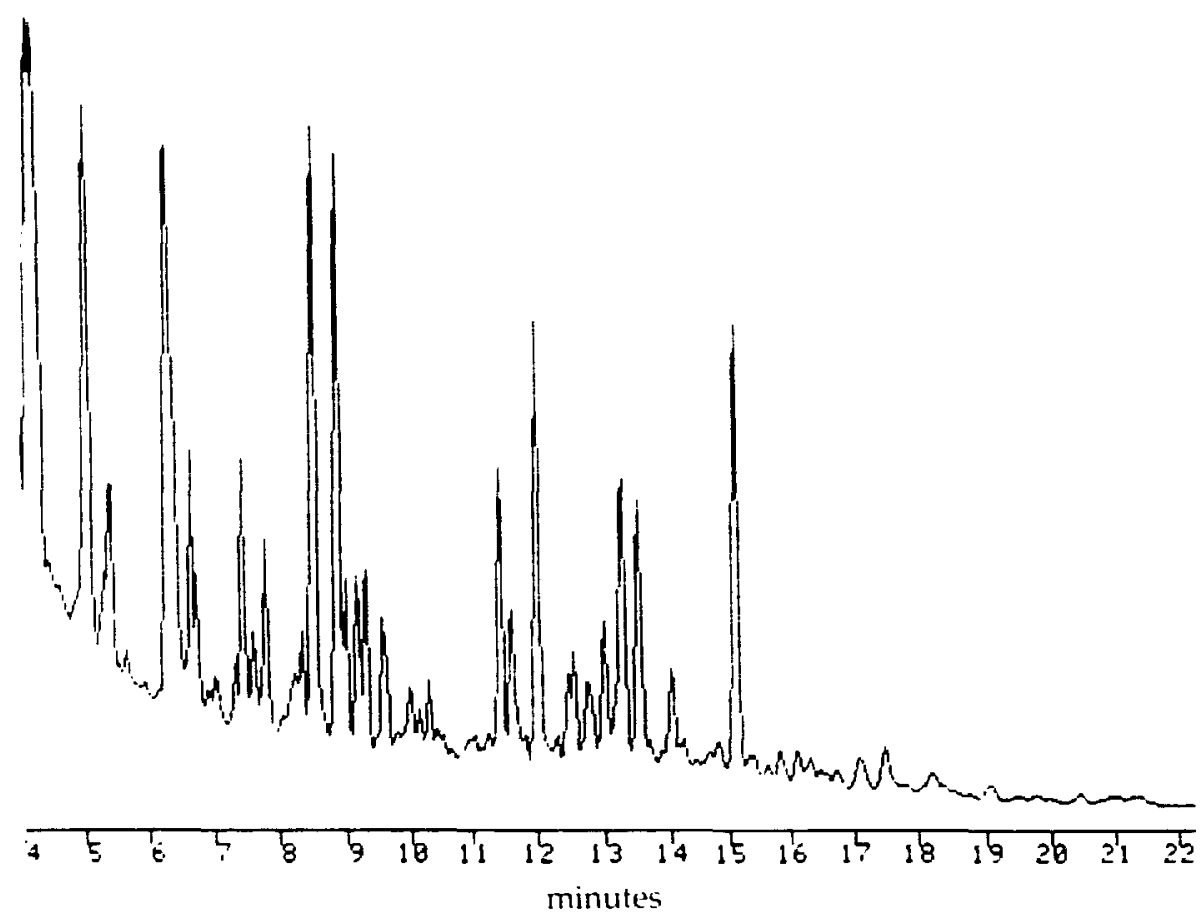

\begin{tabular}{|c|c|}
\hline$T_{1 i}$ & COMPOUND \\
\hline 4.2 & benzaldehyde \\
\hline 5.1 & 1-methyl-1h-indene \\
\hline 5.4 & acetophenone \\
\hline 6.3 & azulene \\
\hline 6.7 & naphthalene \\
\hline 7.5 & 1-methylnaphthalene \\
\hline 7.6 & dioctyladipate \\
\hline.- .4 & 2-methylnaphthalene \\
\hline $8 . i$ & 2,6-ditertiary butyl-p-cresol \\
\hline 8.5 & methyl-1-indene \\
\hline 8.4 & biphenyl \\
\hline 9.2 & 2-methylbiphenyl \\
\hline 9.3 & cinnamaldehyde \\
\hline 9.6 & biphenylene \\
\hline 10.3 & 0 -xylene \\
\hline 11.5 & diphenylmethane \\
\hline 12.0 & fluorene \\
\hline 12.6 & 5-phenyl-1,3-cyclohexadiene \\
\hline 12.8 & benzoic acid \\
\hline 13.0 & diphenylethylene, 1,1-diphenylethene \\
\hline 13.6 & 9,10-dihydrophenanthrene \\
\hline 14.0 & 1,2 diphenylethylene \\
\hline 15.1 & phenanthrene, anthracene \\
\hline 17.1 & 3-phenylcinnoline \\
\hline 17.5 & 2-phenylnaphthalene \\
\hline 24.7 & 2-benzylnaphthalene \\
\hline 25.5 & 2-methylpyrene \\
\hline 33.1 & 2,3,4-tetrahydrotriphenylene \\
\hline
\end{tabular}

Figure B4. Pyrolyzate virgin PVC generated in air in tube pyrolyzer during the main region of degradation separated on Carbowax-20M capillary column. 


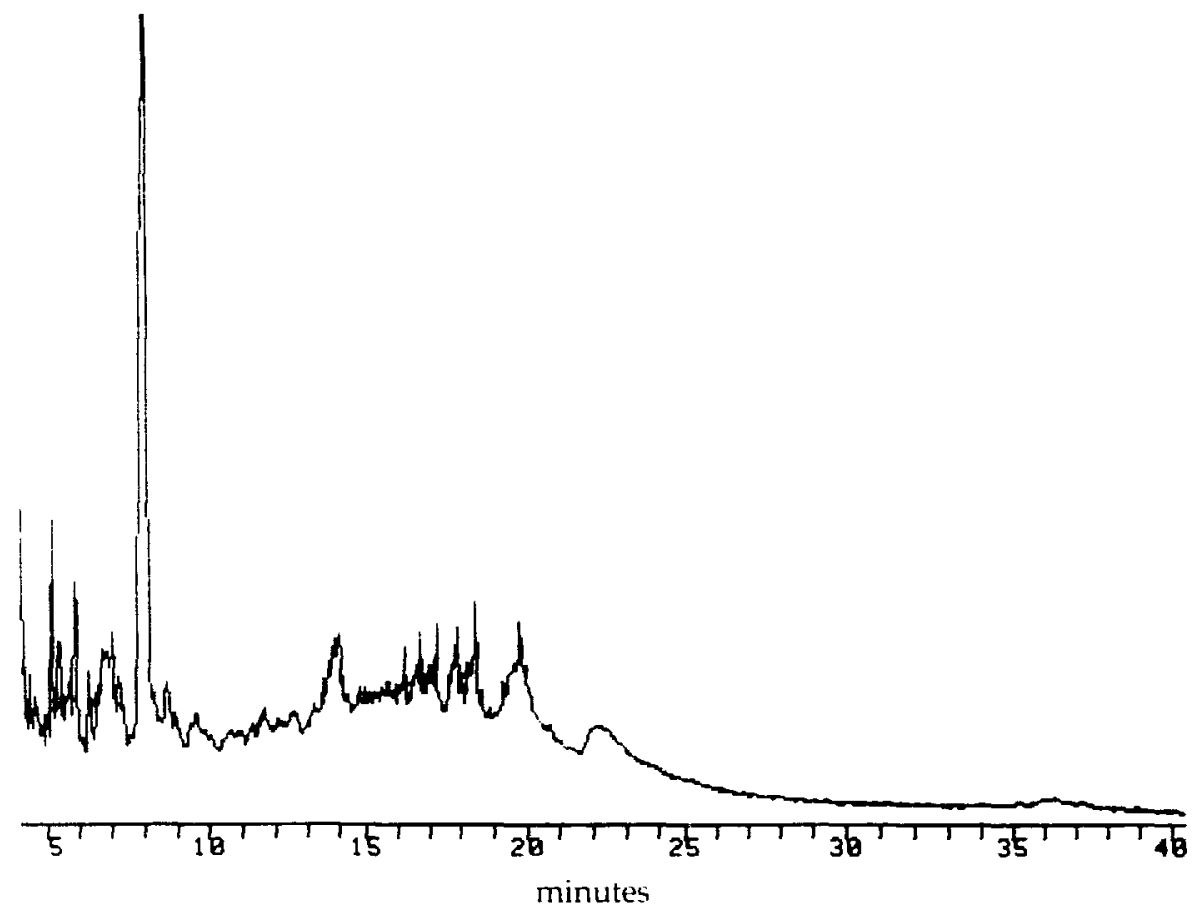

$\begin{aligned} T_{k} & \text { COMPOUND } \\ 4.2 & \text { a-chlorotolucine } \\ 5.2 & \text { phenylcyclopropane } \\ 5.4 & \text { a-chloroethylbenzene } \\ 5.1 & \text { chloroprene dimer } \\ 8.8 & \text { 5,h-benzobicyclo(2,2,1) hept-2-ene } \\ 17.9 & \text { 4,4-dimethoxystilbene }\end{aligned}$

Figure B5. Pyrolyzate of virgin Neoprene generated during the main phase of pyrolysis and separated on SE-54. 


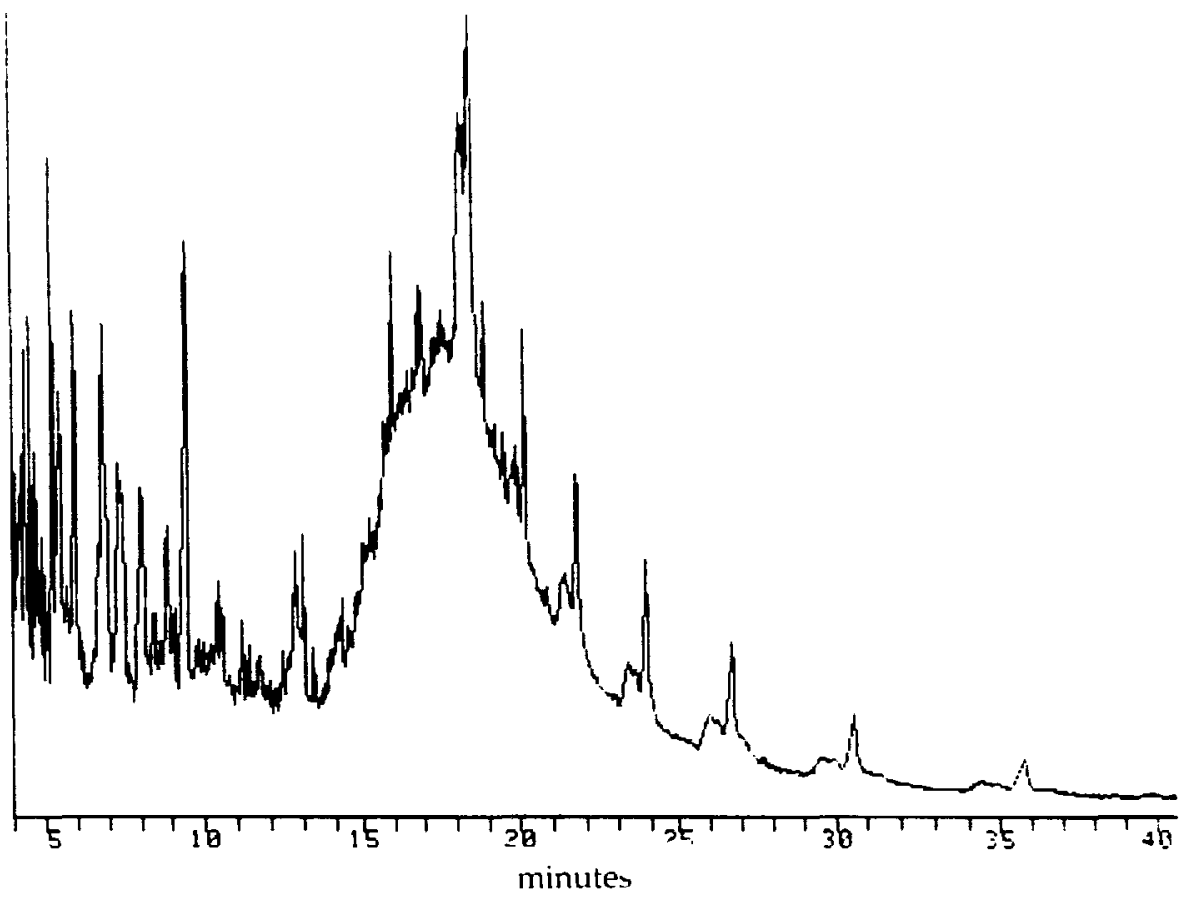

\begin{aligned} \hline $\mathrm{T}_{\mathrm{R}} &$ COMPOUND \\ \hline 4.4 & 1,2 dimethylcyclohexene \\ 4.6 & 2-n-hexyl-n-methyl pyrolidine \\ 4.8 & propylbenzene \\ 5.3 & 3-chlorocyclohexene and methylstyrene \\ 5.5 & o-chloroethylbenzene \\ 6.0 & x-chloro-0-xyiene \\ 6.9 & methylallylbenzene \\ 8.9 & 1-methylnaphthalene and di-n-amylphthalate \\ 9.5 & 3.3,6-trimethyl-1-indanone \\ 12.8 & 1-allylnaphthalene \\ 18.6 & phenyl-B-naphthylamine \\ 20.2 & bis (3,5,5-trimethyl hexyl) adipate \\ 21.8 & di-nor-dodecyl ether \\ 23.9 & x-dodecylcyclohexanol \\ 26.8 & squalene \end{aligned}

Figure B6. Pyrolyzate of Neoprene 007 generated during the main phase of pyrolysis and separated on SE-54. 


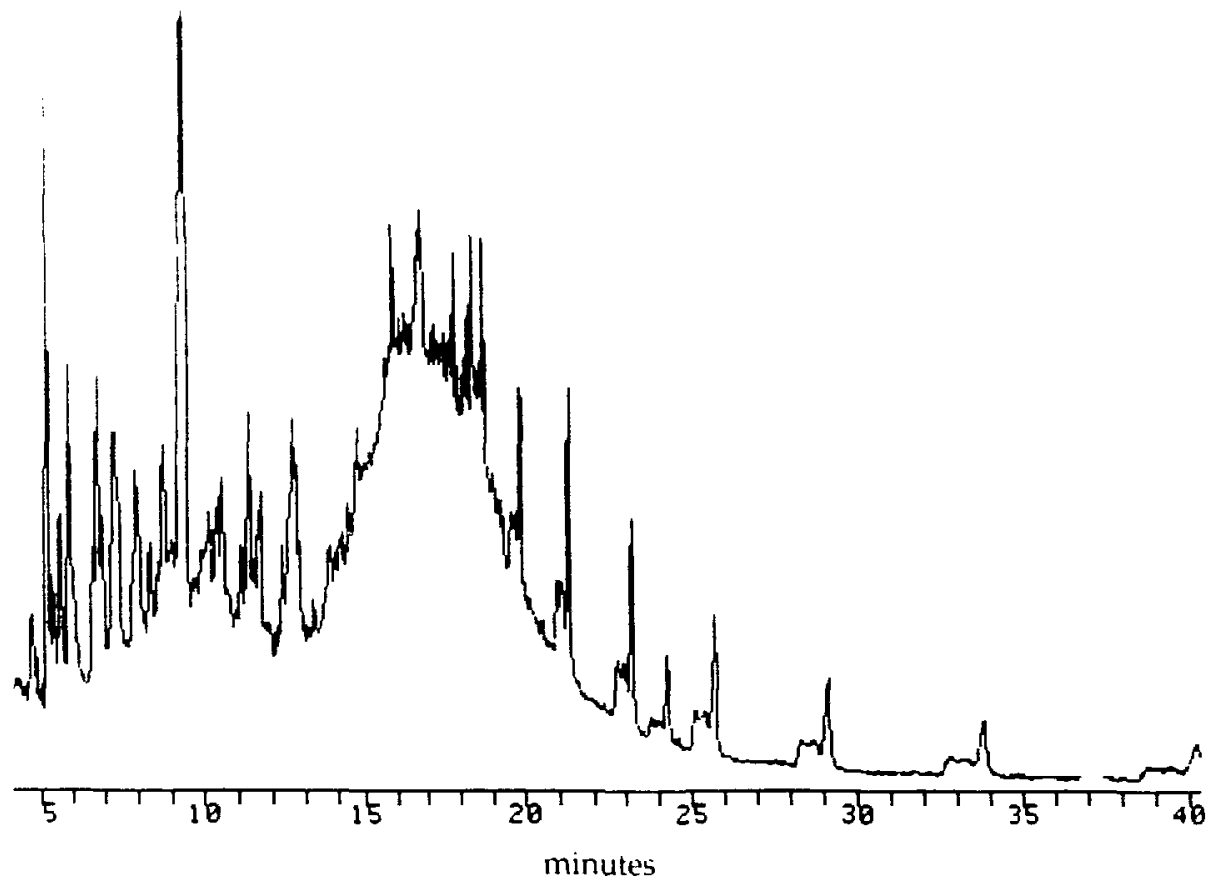

\begin{tabular}{ll}
\hline$\Gamma_{K}$ & COMPOUND \\
\hline 5.2 & 0-methylstyrene \\
5.6 & o-cresol \\
5.9 & p-cresol \\
6.8 & 5 -methyl indan \\
7.3 & naphthalene \\
8.8 & 1-methyl naphthalene \\
9.5 & 7-hydroxy-5,6-benznorbornene \\
11.7 & 1,5,8-trimethyl-1,2,3,4-tetrahydronaphthalene \\
12.7 & 4-methyl-2,6-di-tert-butylphenol \\
16.8 & 1-allylnaphthalene \\
19.9 & 5qualethylbenz(Alanthracene \\
24.3 & dioctylphthalate
\end{tabular}

Figure B7. Pyrolyzate of Neoprene 435 generated during the main phase of decomposition and separated on SE-54 capillary column. 


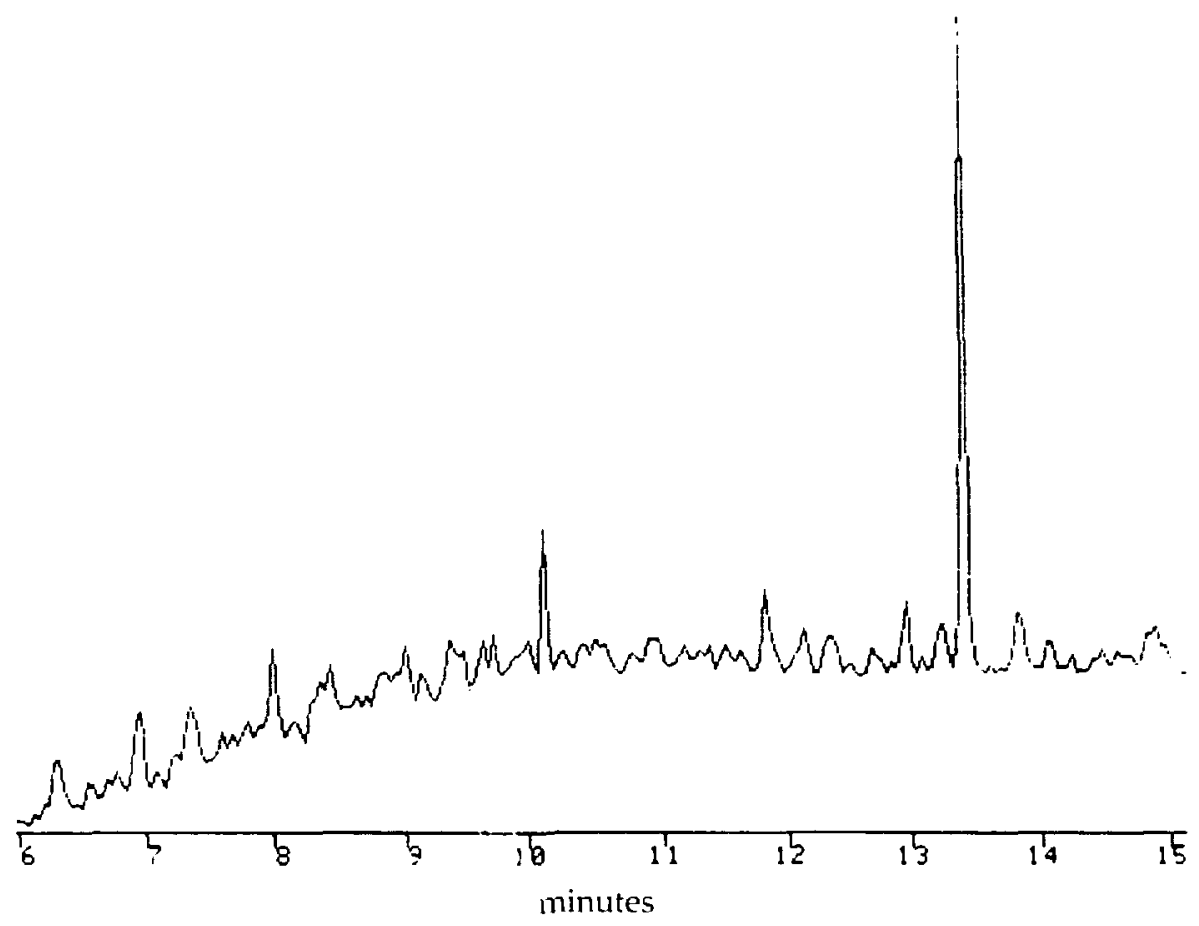

\begin{tabular}{rl}
\hline $\mathrm{T}_{\mathrm{R}}$ & COMPOUND \\
\hline 6.0 & 17-pentatriacontene \\
6.4 & hexadecanol \\
7.1 & $2,3,4$-trimethyl-4,5-methylene-tetradecane \\
8.1 & 2 -(2-octyldecyl)-cis-bicyclo-(3,3)octane \\
10.2 & 2,4 -dimethylquinoline \\
11.9 & 3-ethyl-5-(2-ethylbutyl)-octadecane \\
13.0 & 2-linoleyl-1,3-diac tin \\
13.5 & xanthane
\end{tabular}

Figure B8. Pyrolyzate from rubber-12 generated in TGA furnace during the main phase of degradation and separated on Carbowax-20M capillary column. 


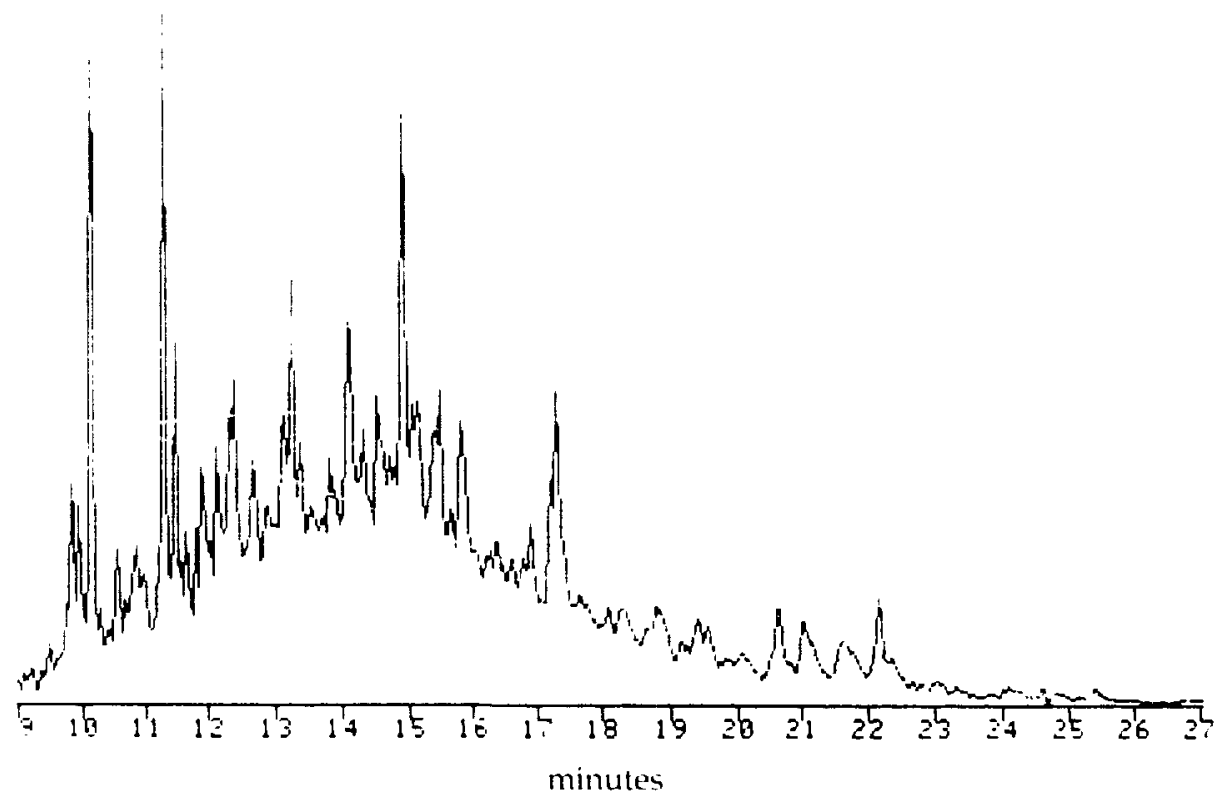

\begin{tabular}{rl}
$\mathrm{T}_{K}$ & COMPOLND \\
\hline 4.4 & 3-methylbiphenyl \\
11.2 & 2.4-dimethylquinoline \\
11.4 & 1,3 -diphenylpropane \\
11.6 & 2.4 -dimethylbiphenyl \\
11.4 & phihlide \\
12.0 & alpha-hydroxy-toluic acid \\
12.5 & 2-methyltridecane \\
13.3 & heptacosane \\
14.2 & nor-pentacosane \\
15.0 & n-hexatriacontane \\
15.6 & nonylphenol \\
15.8 & 3-ethyl-5(2-ethylbutyl) octadecane \\
17.3 & palmitic acid \\
20.7 & triphenyl \\
22.2 & dioctylphthalate
\end{tabular}

Figure B9. Pyrolyzate from rubber-138 generated in TGA furnace during the main phase of degradation and separated on Carbowax-20M capillary column. 


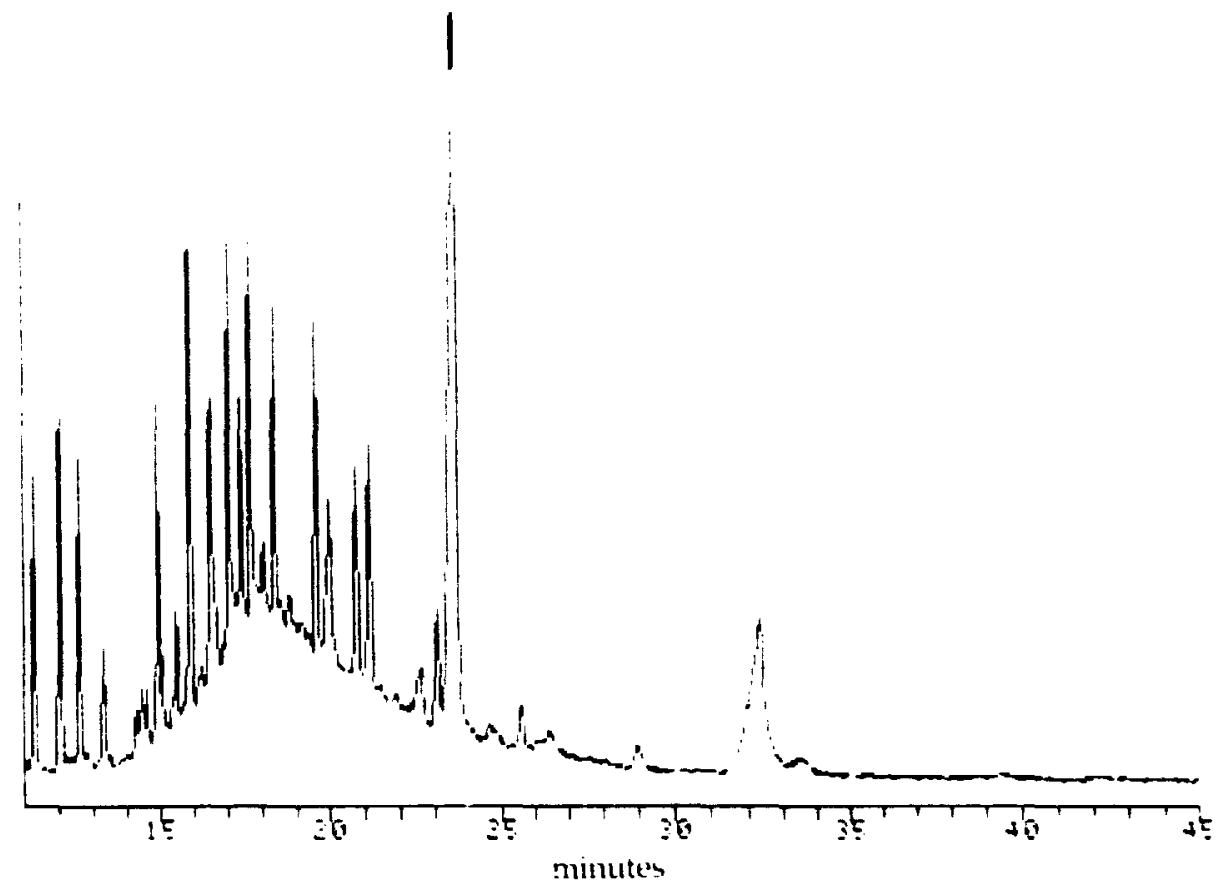

\begin{tabular}{|c|c|}
\hline $\mathbf{r}_{\mathrm{k}}$ & COMPOL(XI) \\
\hline 12.2 & nor-decyl thiol norbutyrate \\
\hline 12.8 & tri-n-nbutyl phosphate \\
\hline 13.5 & 2.5-dihvdroxybenzoic acid \\
\hline 15.1 & butyl-0 -phthalate \\
\hline 13.7 & nor-triocontane \\
\hline 16.0 & butyl(butoxycarbonyllmethyl phthalate \\
\hline $16 .$. & palmitic acid \\
\hline 17.3 & 1.10-bis(1-uicahydronaphthylldecane \\
\hline 17.6 & ll-N-decylducosane \\
\hline 18.6 & ocladecane \\
\hline 19.8 & n-tricosane \\
\hline 20.3 & n-butyl-0-phthalate \\
\hline 21.0 & dioctyl adipate \\
\hline 21.4 & hexatriacontane \\
\hline 23.8 & dioctylphthalate \\
\hline 32.4 & tetracosanol \\
\hline
\end{tabular}

Figure B10. Thermal degradation products of rubber-138 generated in the large-scale test cell and separated on SE-30 fused silica capillary column. 


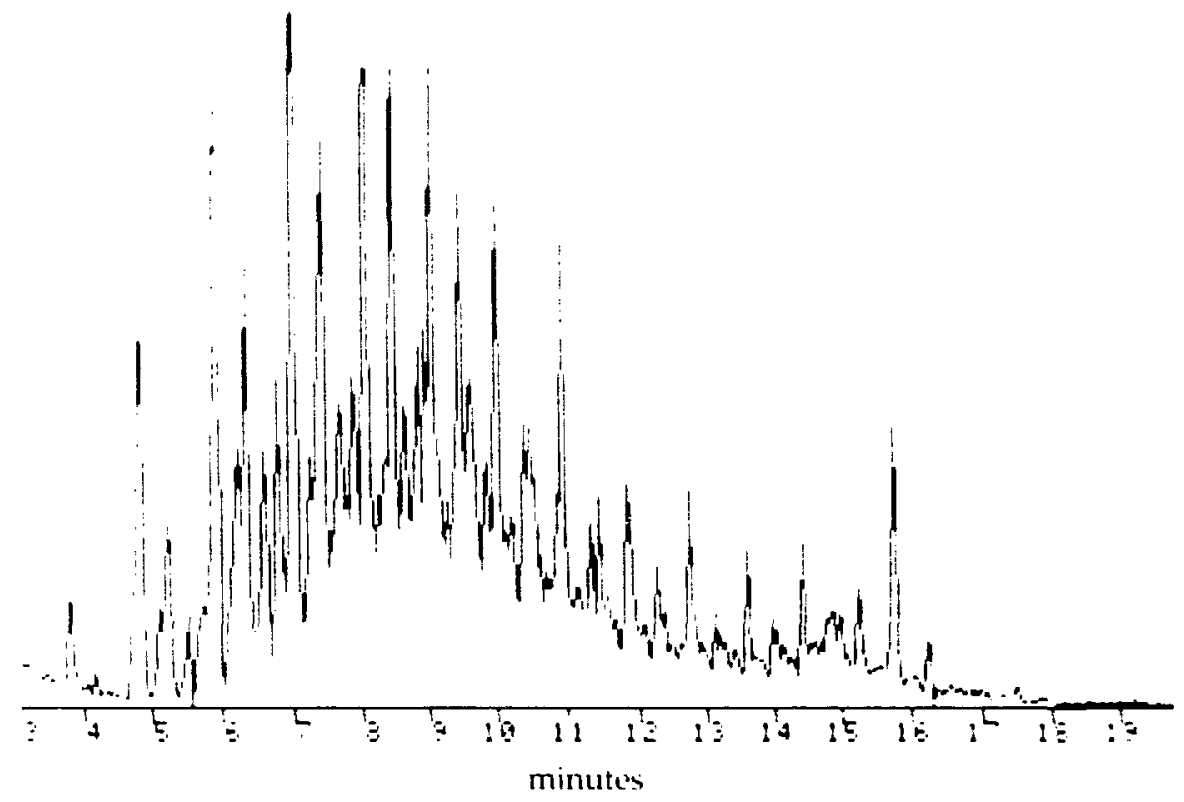

\begin{tabular}{|c|c|}
\hline$I_{k}$ & COMPOLND \\
\hline 3.8 & 1-hexadecent: \\
\hline 4.4 & 1-actadecene \\
\hline 5.3 & 1,12-tridecadiene \\
\hline b.11 & heptacosanol \\
\hline b.t & linuleic acid \\
\hline b.h & oleic acid \\
\hline h.s & 1-dotriacontanol \\
\hline .11 & 1,12-tridecadiene \\
\hline 7.7 & 2-hexanal \\
\hline 7.9 & l-undecyne \\
\hline 8.1 & 1-dotriacontanol \\
\hline 8.5 & oleyl alcohol \\
\hline 9.5 & 2-cis-9-octadecenyloxy ethanol \\
\hline 10.1 & octadecanol-1 \\
\hline 10.5 & 2D-methyl-1-octen-7-ol \\
\hline 11.0 & 1-docosene \\
\hline 11.9 & $\begin{array}{l}\text { 1,7-dicyclopentyl-4-(3prim- } \\
\text { cyclopentypropyl)- } \\
\text { heptane }\end{array}$ \\
\hline 12.8 & hexadecanol \\
\hline 13.6 & heptadecanyl acetate \\
\hline 15.3 & 1-docosanol \\
\hline
\end{tabular}

Figure B11. Pyrolyzate of virgin polyethylene generated during the main phase of degradation and separated on Carbowax-20M. 


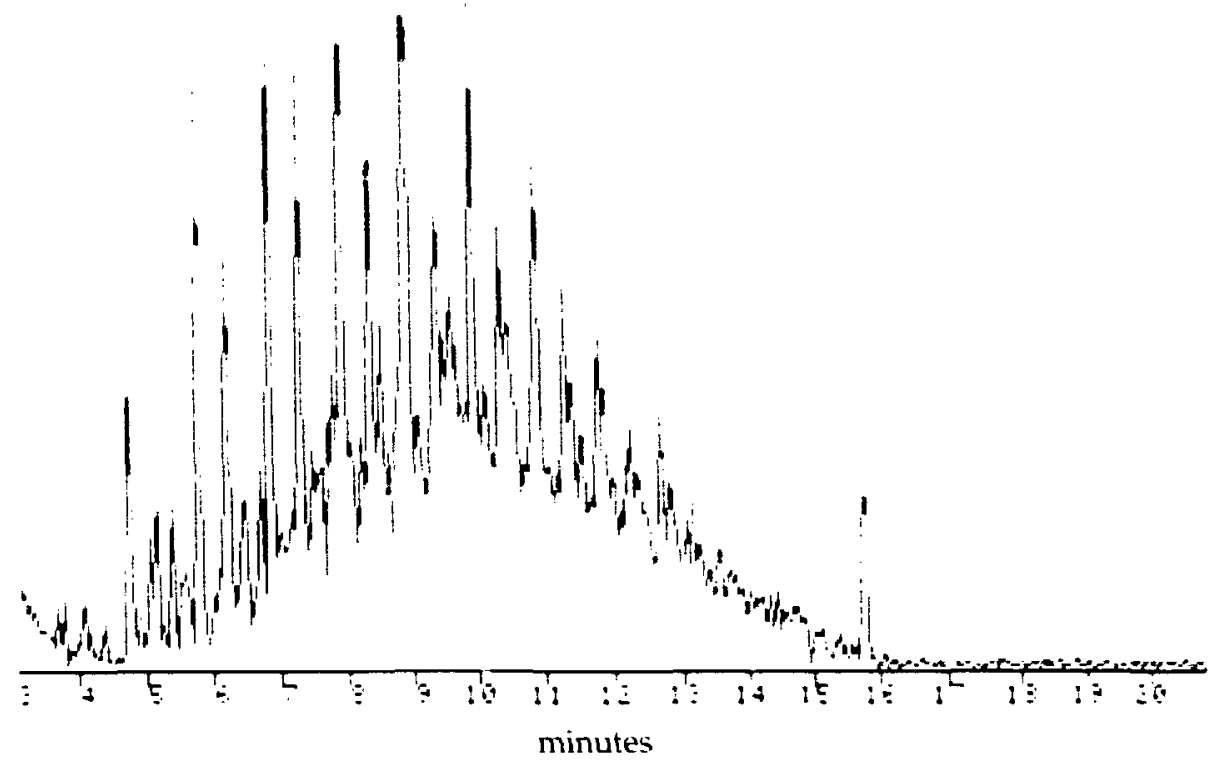

\begin{tabular}{rl}
\hline$T_{18}$ & COMPOUND \\
\hline 4.7 & hexadecanol-1 \\
5.4 & 1-hexadecene \\
6.3 & 1,4 -dicyclopentylbutane \\
6.4 & 2L-methyl-dodecanol-1 \\
7.4 & tridecanal \\
8.0 & octadecanol-1 \\
8.4 & octadecanal \\
4.0 & tetradecanol \\
9.4 & oleyl alcohol \\
10.9 & heptadecanyl acetate \\
11.3 & 1-N-amylcyclohexene-1 \\
12.7 & hexadecanol
\end{tabular}

Figure B12. Pyrolyzate from polyethylene 77 generated during the main phase of pyrolysis in a TGA furnace and separated on Carbowax-20M column. 


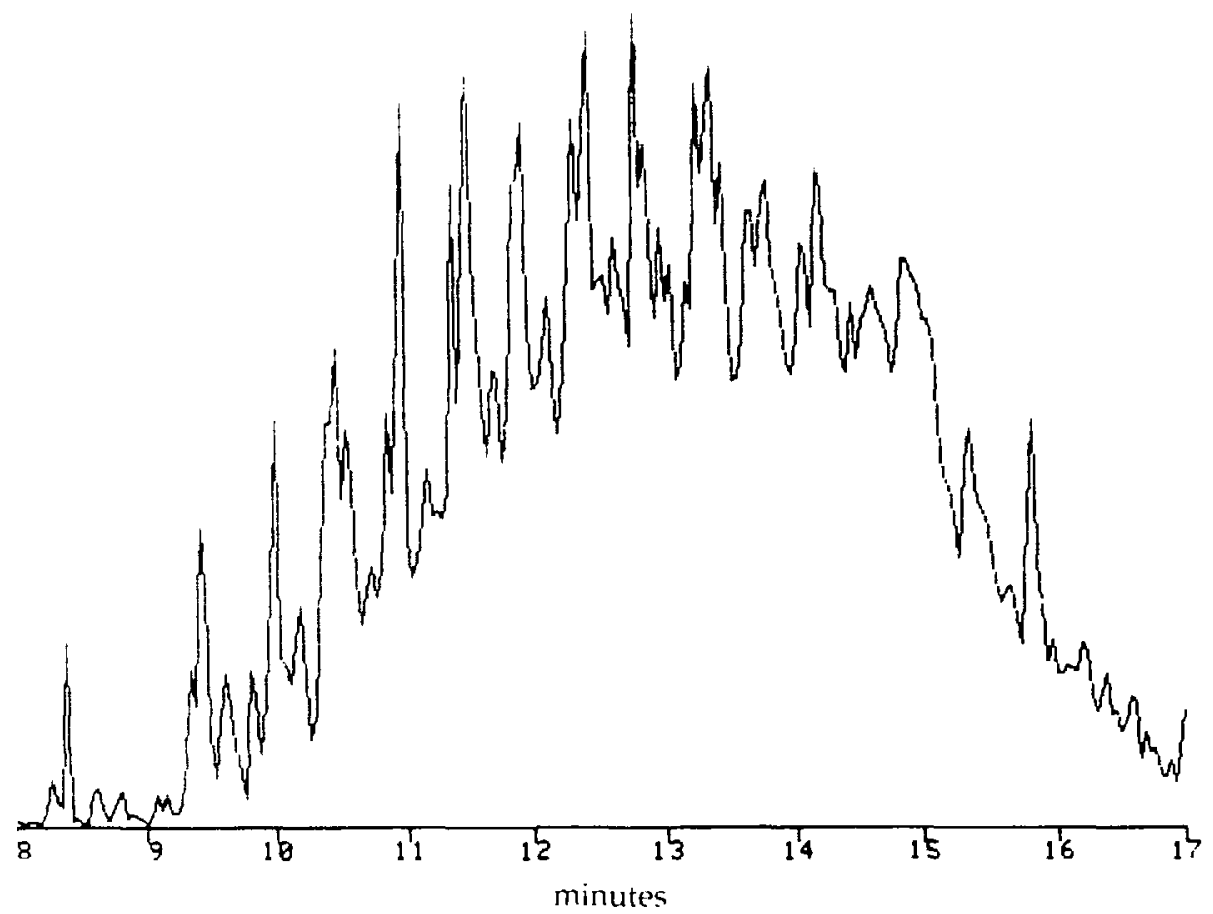

\begin{tabular}{|c|c|}
\hline $\mathrm{T}_{18}$ & COMPOUND \\
\hline 8.5 & cis-henahydroindane \\
\hline 4.5 & tricyclo $(5,2,1,0: 2,6:)$ decan-3-ol \\
\hline 111.1 & 1,12-tridecadiene \\
\hline 10.5 & spiru $(5,6)$ dodecane \\
\hline 11.1 & methy $1-4,12$-hexadecadienoate \\
\hline 1.5 & methyl $C_{4} C_{5}$ octadecadienoate \\
\hline 12.11 & l-dodecyne \\
\hline 12.5 & thujyl alcohol \\
\hline 12.8 & methyl linoleate \\
\hline 13.9 & $\begin{array}{l}\text { 7,7-dimethyl-3-methylen-bicyclo- } \\
(3,1,1) \text { heptane }\end{array}$ \\
\hline 14.2 & methyl heptadeca-5,8,11-trienoate \\
\hline 15.0 & di-n-butylphthalate \\
\hline 15.4 & 1,4-dihydroxy-2(1H)-quinolone \\
\hline
\end{tabular}

Figure B13. Pyrolyzate of polyethylene-95 generated in TGA furnace during the main phase of degradation and separated on Carbowax-20M capillary column. 

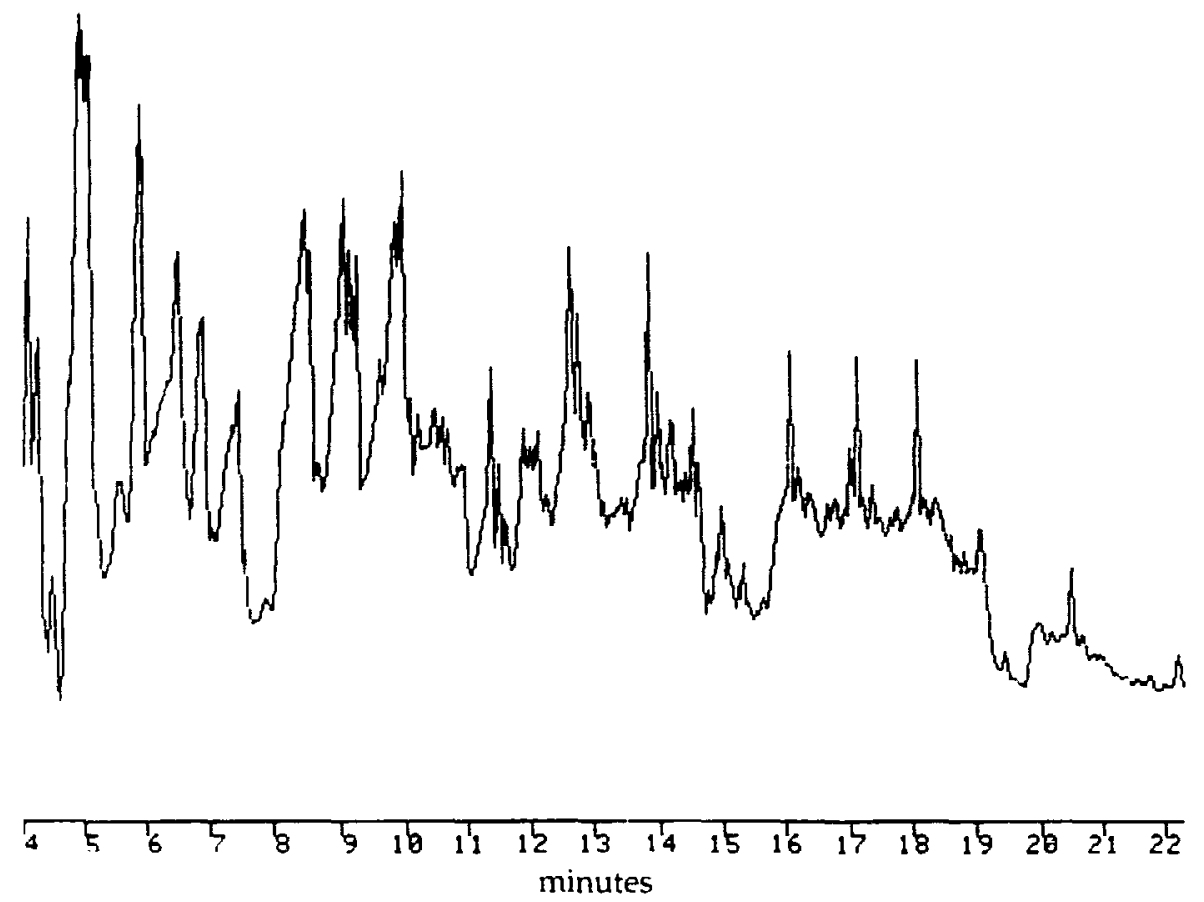

\begin{aligned} \hline$T_{\mathrm{R}} &$ COMPOUND \\ \hline 4.6 & 1,2,4-trimethylbenzene \\ 6.6 & trans-3-methyl-z-t: :enyl methyl ether \\ 9.3 & hexahydrofarnesol \\ 12.0 & 4-ethyldicyclohexylmethane \\ 12.1 & ascaridole \end{aligned}

Figure B14. Pyrolyzate from virgin polypropylene generated in TGA furnace during the main phase of degradation and separated on Carbowax-20M capillary column. 


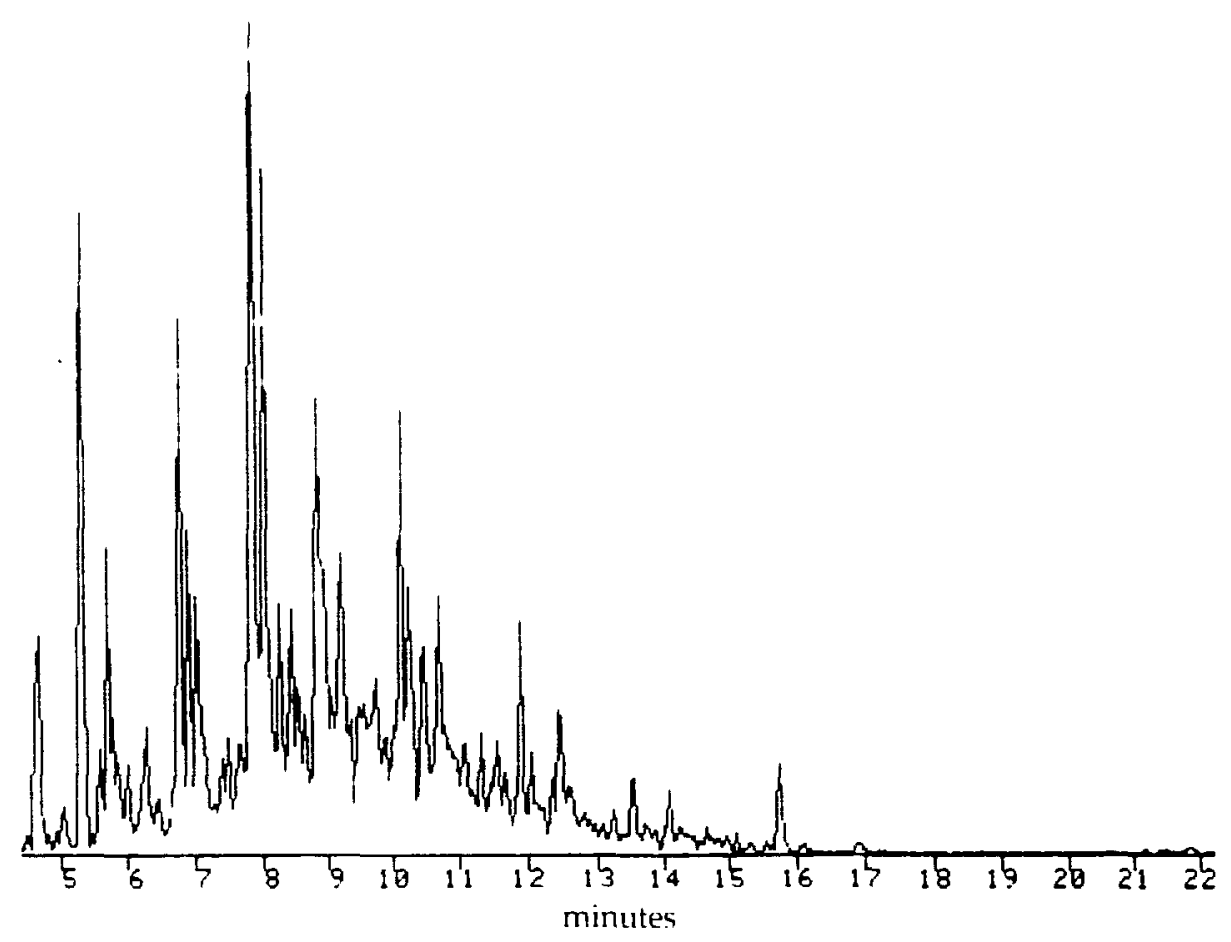

\begin{tabular}{ll}
$\mathrm{T}_{K}$ & COMPOUND \\
\hline 4.7 & trans-3,4-dimethyl-3-hexen-2-one \\
5.4 & t-methylpent-3-enoic acid \\
5.8 & 2-t-butylcyclobutanone \\
6.8 & isobutylcyclopentane \\
7.1 & methyl tert butyl acrolein \\
7.4 & 6-methyl-5-hepten-2-one \\
8.0 & 1.3-diaminocyclohexane \\
4.3 & 5-hexn-2-one \\
8.4 & 4-methyl-pent-4-en-2-one \\
4.3 & nona-3-ene-2-one \\
10.2 & 3.4-epoxy-2-hexanone \\
10.5 & 2,4-xylenol \\
10.8 & hexadecanol \\
11.9 & cis-2,5-dimethyl-tetrahydrofuran \\
12.5 & 2,5-dimethyl-2-hexene
\end{tabular}

Figure B15. Pyrolyzate from propylene-90 generated in TGA furnace during the main phase of degradation and separated on Carbowax-20M capillary column. 


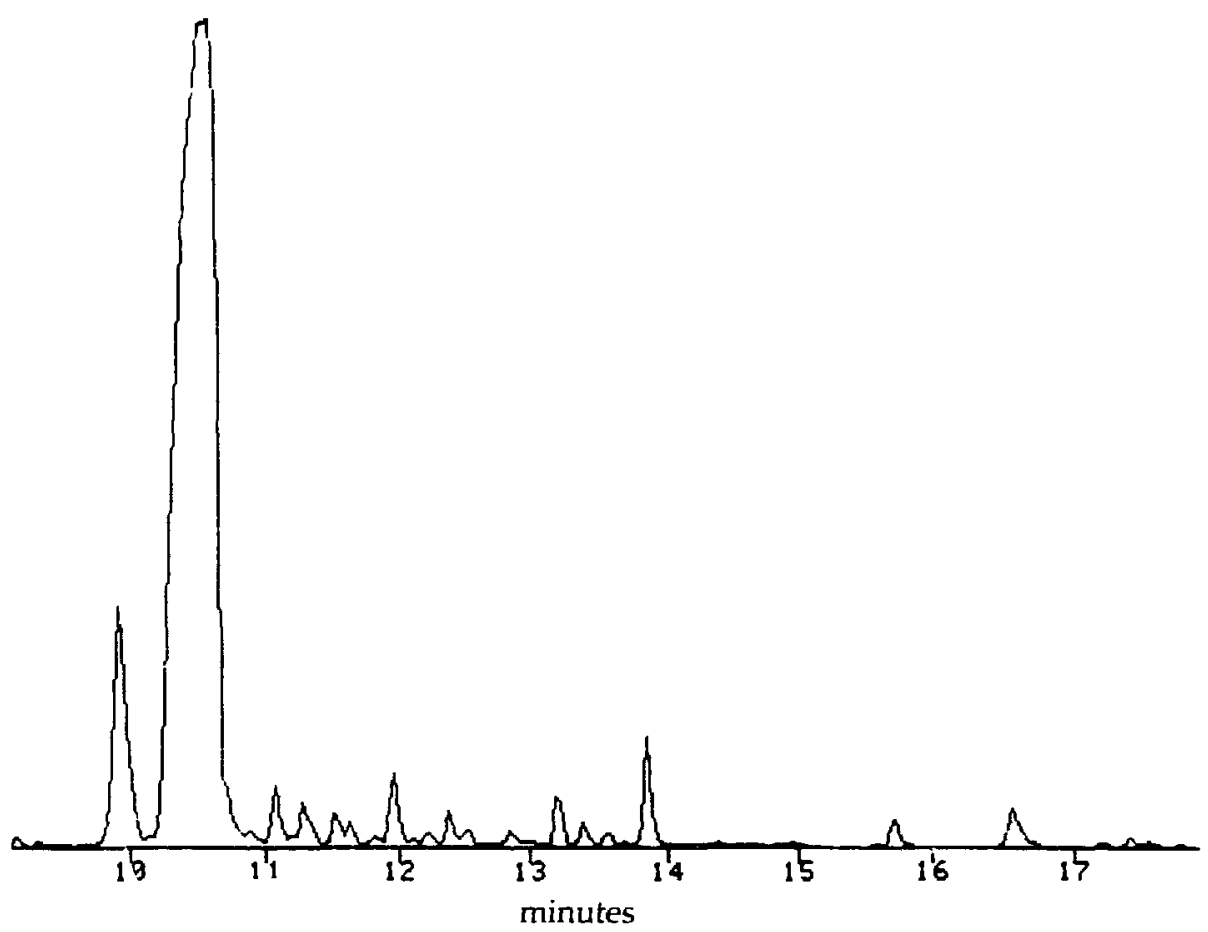

\begin{tabular}{cl}
\hline$T_{R}$ & COMPOUND \\
\hline 10.0 & 2,3-dimethylpyrimide-4-one \\
10.6 & 1-hexene \\
11.1 & 5-methyl-2-pyridone \\
11.3 & $4,6,6$-trimethyl- $\delta$-valerolactone \\
12.0 & e-caprolactam \\
13.9 & 1-methylimidazole \\
15.7 & 1-methylbutyl isobutyrate \\
16.6 & ethyl-(1', 3'-dimethlybutyl)amine \\
21.1 & methyl-succinic acid \\
22.6 & cyclododecane
\end{tabular}

Figure B16. Pyrolyzate of nylon insulation generated in TGA furnace and separated on Carbowax$20 \mathrm{M}$ capillary column. 


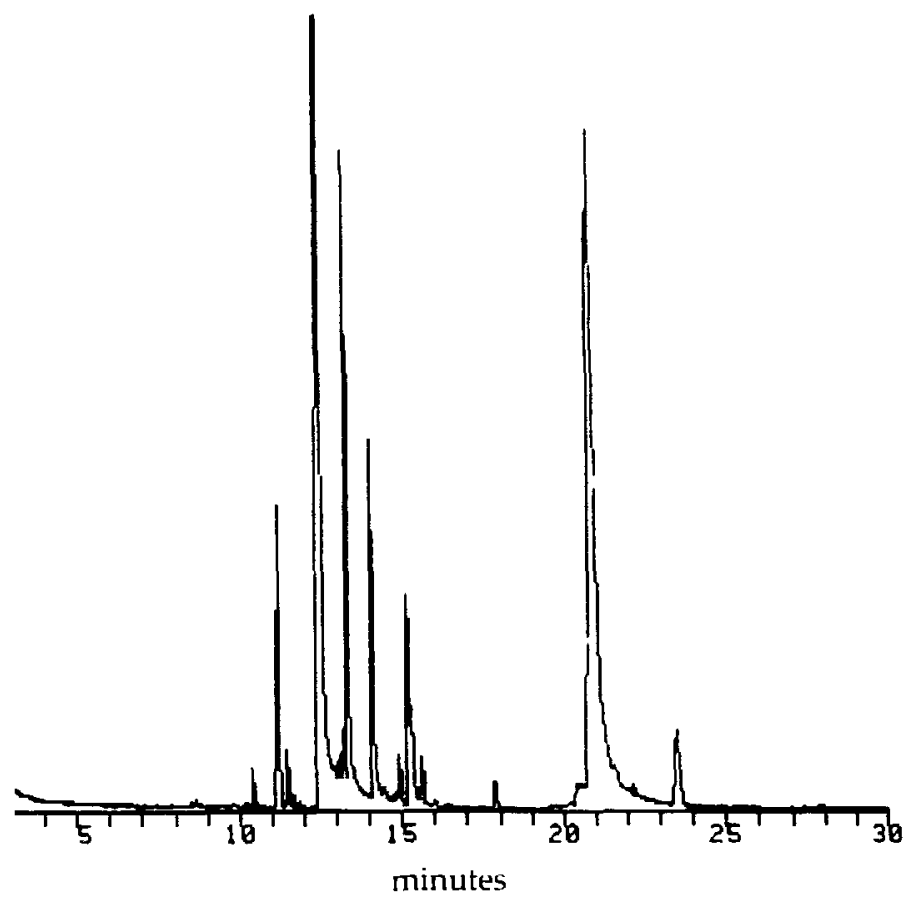

\begin{tabular}{cl}
\hline$T_{\mathrm{R}}$ & COMPOUND \\
\hline 12.5 & benzoic acid \\
13.4 & methyl benzoate \\
14.2 & ethyl benzoate \\
15.2 & isobutyl cinnamate \\
20.9 & isopropyl phthalate \\
23.6 & phenyl benzoate
\end{tabular}

Figure B17. Pyrolyzate from virgin mylar generated in TGA furnace during the main phase of degradation and separation on carbowax $20 \mathrm{M}$ column. 


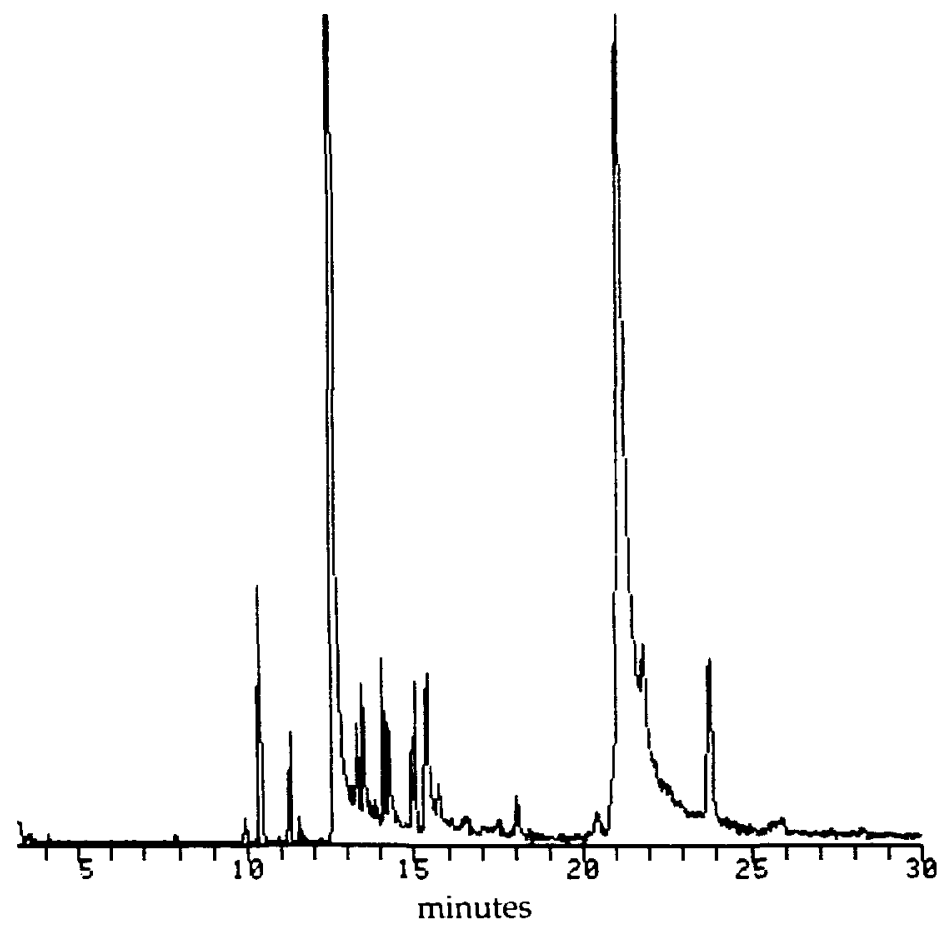

\begin{tabular}{cl}
\hline$T_{R}$ & COMPOUND \\
\hline 10.5 & caprolactam \\
12.6 & benzoic acid \\
13.5 & methyl benzoate \\
15.4 & isobutyl cinnamate \\
21.2 & isopropyl phthalate \\
23.9 & phenyl benzoate
\end{tabular}

Figure B18. Pyrolyzate from mylar \#139 generated in TGA furnace during the main phase of degradation and separation on Carbowax $20 \mathrm{M}$ column. 